\title{
WestVirginiaUniversity
}

THE RESEARCH REPOSITORY @ WVU

Graduate Theses, Dissertations, and Problem Reports

2005

\section{Nesting success and nest site characteristics of four thrush species on a managed forest}

Rachel Dellinger

West Virginia University

Follow this and additional works at: https://researchrepository.wvu.edu/etd

\section{Recommended Citation}

Dellinger, Rachel, "Nesting success and nest site characteristics of four thrush species on a managed forest" (2005). Graduate Theses, Dissertations, and Problem Reports. 2259.

https://researchrepository.wvu.edu/etd/2259

This Dissertation is protected by copyright and/or related rights. It has been brought to you by the The Research Repository @ WVU with permission from the rights-holder(s). You are free to use this Dissertation in any way that is permitted by the copyright and related rights legislation that applies to your use. For other uses you must obtain permission from the rights-holder(s) directly, unless additional rights are indicated by a Creative Commons license in the record and/ or on the work itself. This Dissertation has been accepted for inclusion in WVU Graduate Theses, Dissertations, and Problem Reports collection by an authorized administrator of The Research Repository @ WVU.

For more information, please contact researchrepository@mail.wvu.edu. 


\section{NESTING SUCCESS AND NEST SITE CHARACTERISTICS OF FOUR THRUSH SPECIES ON A MANAGED FOREST}

\section{RACHEL DELLINGER}

Dissertation submitted to the Davis College of Agriculture, Forestry, and Consumer Sciences at West Virginia University in partial fulfillment of the requirements for the degree of

DOCTOR OF PHILOSOPHY

in

Forest Resource Science: Wildlife and Fisheries Resources

Petra Bohall Wood, Ph.D., Chair John R. Brooks, Ph.D.

John W. Edwards, Ph.D.

Mary Ann Fajvan, Ph.D.

Patrick D. Keyser, Ph.D.

Cathy A. Weakland, Ph.D.

Division of Forestry

Morgantown, West Virginia 2005

Keywords: American Robin, even-aged harvest, habitat partitioning, Hermit Thrush, partial harvest, Veery, Wood Thrush 


\section{ABSTRACT \\ NESTING SUCCESS AND NEST SITE CHARACTERISTICS OF FOUR THRUSH SPECIES ON A MANAGED FOREST}

\section{RACHEL DELLINGER}

Four thrush species breed sympatrically in the Allegheny Mountain region of West Virginia, U.S.A.: American Robin (Turdus migratorius), Hermit Thrush (Catharus guttatus), Veery (Catharus fuscescens), and Wood Thrush (Hylocichla mustelina). The four often nest in close proximity to one another, suggesting habitat partitioning may have developed in the past to minimize interspecific competition and/or nest predation rates; however, specifics of how nesting habitat is partitioned remain unclear. Furthermore, it is unknown how forest disturbance caused by logging activities may affect the guild as a whole. My objectives were to identify the specific characteristics of nesting habitat that are partitioned among these four thrush species and to determine their effects on nest survival.

I conducted point count surveys and monitored nests of four thrush species on a managed forest. At each nest, I measured habitat variables at three spatial scales: (1) nest substrate, (2) nest site, and (3) territory. I also measured nest site variables at paired, random plots. Using GIS software, I then digitized land cover into five land covers: deciduous and mixed mature forest, deciduous and mixed partial harvest, and even-aged regeneration harvest. I investigated thrush use of mature forests and areas subjected to even-aged regeneration harvesting and partial harvesting by measuring frequency of occurrence, nest survival, and nest site characteristics of the species within each land cover. Furthermore, I examined the effect of land covers at the microhabitat scale.

Habitat partitioning among the four thrush species occurred at all three scales sampled, and the most important partitioning variables included nest height, distance to edge, sapling density, and elevation. Wood Thrush used lower elevation, primarily closed-canopy forests; Veery was distinguished by nesting in low shrub layer in areas of high sapling density; Hermit Thrush was the only species to nest on the ground, with some individuals displaying the uncommon behavior of nesting on boulders or in trees; and the American Robin overlapped considerably with other species at all three scales.

Wood Thrushes occurred more often than would be expected in deciduous partial harvests, increased in occurrence as the percent of partial harvests increased on the landscape, and had higher nest survival in partially harvested stands than they did in mature forest. In contrast, the other three species selected against deciduous partial harvests and had lower nest survival within them than they did in mature forest. Hermit Thrushes selected for mature mixed forest and selected against mature deciduous forest, even-aged harvests, and harvested edges. Hermit Thrushes never nested in even-aged harvests of any age but placed their nests in areas that were disturbed $>10$ years ago by secondary logging activities such as road building and the seeding of log landings and skid trails. American Robins, Veeries and Wood Thrushes did not avoid the edges of even-aged harvests, and nested within harvested stands beginning at four years post-harvest. 
For the American Robin, Veery, and Wood Thrush, nest survival was highest in evenaged harvests; and for all but the Wood Thrush, it was lowest in partial harvests and intermediate in mature forest. Of the variables related to habitat partitioning, decreasing nest height was positively related to the survival of American Robin nests. Overall, nest survival was similar among the four thrush species and most of the variables I measured were unrelated to survival; thus, the guild appears to be partitioning the available habitat successfully and to be tolerant of forest disturbance at its current intensity. 


\section{ACKNOWLEGMENTS}

I would like to thank my graduate committee for all their help in the completion of this dissertation. I am grateful to Dr. Petra Wood for her patience and for her expert reviewing of this and other manuscripts; to Dr. John Brooks for help with statistics and tree identification, and for maintaining a sunny disposition; to Dr. John Edwards for his insight into competition and habitat selection, and for his sense of humor; to Dr. Mary Ann Fajvan for her excellent silviculture class and for always contributing a forester's perspective to this dissertation; to Dr. Pat Keyser for being such an excellent liaison between MeadWestvaco and the research taking place at the MWERF; and to Dr. Katie Weakland for assistance and advice in the field, help with SAS, and all those great Bible studies. I also appreciate Dr. George Seidel for his many hours of cheerful statistical guidance, and Becky Nestor for everything she did behind the scenes; if I had her common sense and organizational skills I wouldn't need a Ph.D.

I am grateful to my funding sources: MeadWestvaco Corporation, NCASI, the West Virginia Cooperative Fish and Wildlife Resource Unit, and the West Virginia University Division of Forestry, with special thanks to Dr. Ben Wigley of NCASI, Dr. Pat Keyser of MeadWestvaco, and Dr. Joe McNeel of the WVU Division of Forestry.

This research would not have been possible without assistance in the field from the following graduate students, technicians, and volunteers: Tim Dellinger, Katie Weakland, Gary Williams, Rebecca Smith, Andy Zadnik, Scott Bosworth, Debbie Duvall, Andy Bennett, Jonica Martin, Brian Carver, Jack Jenkins, Julie Copiz, Lisa Kendall, Kevin Boyle, John Coniff, Clint Chisler, Jen Benson, Julie Webber, Sandy Bradstreet, Masako Ogawa, Ray George, Justin

Tincher, Tom Hardman, Andy Cole, Brian Brezenski, Brian Scharle, and Tim Seifert. It was a pleasure getting to know the other graduate students who lived and worked at the bunkhouse, 
especially Lori Williams, Kate Wright Kelly, and the late Jeff Kaminski. We miss you, Jeff, and I am sure your "majestic animals of diminutive stature" do too.

I also would like to thank the citizens of the great towns of Adolph, Cassity, and Mabie, West Virginia for tolerating the MeadWestvaco Research Station and its activities within their communities. I would especially like to thank all the members of Harrison Community Church who welcomed us with open arms and prayed for us. You are salt and light, and your lives are examples for the rest of us to follow.

I could not have made it through graduate school without the encouragement of both my immediate and extended families, and I appreciate all they did for me while I lived in West Virginia. Thanks especially to the Reverend Dr. Clyde Ridall for his challenge of a 585-page dissertation written in two languages on a manual typewriter.

I would like to thank my husband Tim Dellinger for moving to Morgantown to experience graduate school with me. I hope the Cerulean Warblers in the back yard helped make up for the world's driest well, one snowy TV channel, and those big dump trucks and Harleys roaring past our window at all hours. What a crazy four years it has been! And lastly, thank you to William Dellinger, who came along at just the right time to remind me of what really matters in life, and who keeps me laughing. 


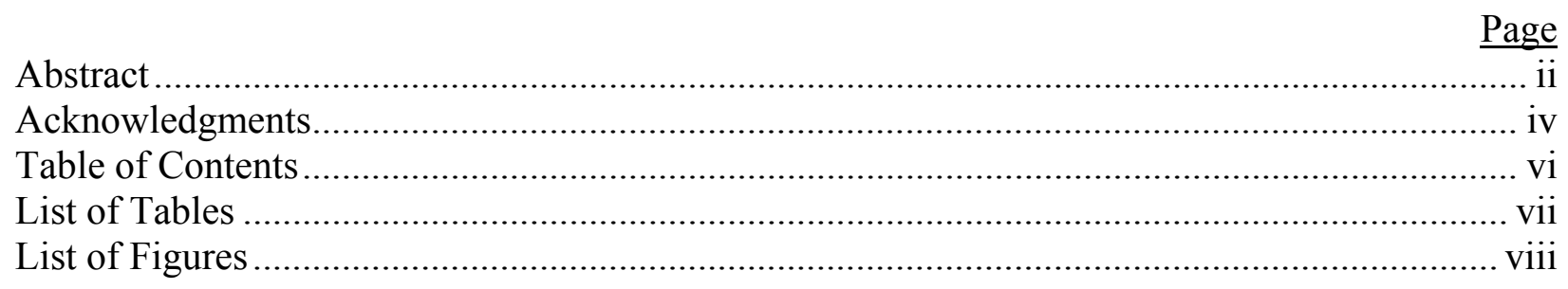

\section{CHAPTER 1: INTRODUCTION}

Introduction...

CHAPTER 2: HABITAT PARTITIONING OF FOUR SYMPATRIC THRUSH SPECIES AT THREE SPATIAL SCALES ON A MANAGED FOREST IN WEST VIRGINIA

Abstract

CHAPTER 3: OCCURRENCE AND NEST SURVIVAL OF FOUR THRUSH SPECIES ON A MANAGED CENTRAL APPALACHIAN FOREST

Abstract ........

VITA. 


\section{LIST OF TABLES}

\section{CHAPTER 2:}

$\underline{\text { Page }}$

Table 1. Descriptions of habitat variables sampled at 141 thrush nests during 2001-2003 in Randolph County, West Virginia.

Table 2. Results of MANOVA to determine overall differences in habitat variables sampled at 141 nest sites of four thrush species during 2001-2003 in Randolph County, West Virginia.......48

Table 3. Means and standard errors (SE) of variables sampled at 141 thrush nests during 20012003 in Randolph County, West Virginia.

Table 4. Percent of nests ( $n=141$ ) of each of four thrush species sampled during 2001-2003 in Randolph County, West Virginia that were correctly and incorrectly classified using a classification tree analysis at each of three spatial scales

Table 5. Reduction in diversity measures provided by splitting at variables in recursive classification models for habitat variables sampled at thrush nests $(n=141)$ during 2001-2003 in Randolph County, West Virginia.

Table 6. Percent of nests ( $n=119)$ of four thrush species monitored during 2001-2003 in Randolph County, West Virginia with habitat features present within a 4.0 ha plot centered on the nest

Table 7. Percent of nests ( $n=141)$ of four thrush species monitored during 2001-2003 in Randolph County, West Virginia located on lower, middle, and upper slopes, and results of Fisher's Exact tests for differences in slope position.

Table 8. Survival rates of 128 nests for which survival was calculated, monitored during 20012003 in Randolph County, West Virginia....

\section{CHAPTER 3:}

Table 1. Percent of land cover categories present on the MeadWestvaco Wildlife and Ecosystem Research Forest (MWERF) and the Panther Run Tract, Randolph County, West Virginia during 2001-2003

Table 2. Microhabitat variables measured in 0.04 ha circular plots at the nest sites of four thrush species and at random sites at the MeadWestvaco Wildlife and Ecosystem Research Forest and the Panther Run Tract, Randolph County, West Virginia during 2001-2003. 
Table 3. Chi-square goodness-of-fit analysis and Bonferroni 95\% confidence intervals (C.I.) for the occurrence of four thrush species in relation to the availability of land cover types on the MeadWestvaco Wildlife and Ecosystem Research Forest and the Panther Run Tract, Randolph County, West Virginia

Table 4. Nest survival rate and standard error (SE) of nests, and $\chi^{2}$ contingency table analysis within each thrush species among forest cover types on the MeadWestvaco Wildlife and Ecosystem Research Forest and the Panther Run Tract, Randolph County, West Virginia.....

Table 5. Means and standard errors (SE) of microhabitat variables sampled at randomly located plots within three land cover categories at the MeadWestvaco Wildlife and Ecosystem Research Forest and the Panther Run Tract, Randolph County, West Virginia

Table 6. Microhabitat variables that differed between the nest sites of four thrush species and paired, randomly located plots at the MeadWestvaco Wildlife and Ecosystem Research Forest and the Panther Run Tract, Randolph County, West Virginia.

Table 7. Variables measured at nest sites of four thrush species that differed among nests placed within three land cover categories at the MeadWestvaco Wildlife and Ecosystem Research Forest and the Panther Run Tract, Randolph County, West Virginia

\section{LIST OF FIGURES}

\section{CHAPTER 2:}

Fig. 1. Classification tree for substrate variables collected at thrush nests $(n=113)$ during 20012003 in Randolph County, West Virginia

Fig. 2. Classification tree for nest site scale variables collected at 141 thrush nests during 2001-

2003 in Randolph County, West Virginia .55

Fig. 3. Classification tree for territory scale variables sampled at 141 thrush nests during 20012003 in Randolph County, West Virginia .56 
CHAPTER 1 INTRODUCTION 
FOUR SPECIES from the avian family Turdidae breed sympatrically in the Allegheny Mountain region of West Virginia: American Robin (Turdus migratorius), Hermit Thrush (Catharus guttatus), Veery (C. fuscescens), and Wood Thrush (Hylocichla mustelina) (all nomenclature is taken from the American Ornithologist's Union Checklist of North American Birds, AOU 2004). Hermit Thrush and Veery are members of the genus Catharus, which is considered a monophyletic group (Outlaw et al. 2003). Wood Thrush and American Robin are closely related to the group, but their exact systematic placement remains equivocal (Dilger 1956c, Avise et al. 1980). Catharus was at one time included in Hylocichla along with the Wood Thrush (American Ornithologists' Union 1957); some have recommended that Wood Thrush now also be included in Catharus, partly based on more recent molecular data (Hendrickson and Yow 1973, Avise et al. 1980, Winker and Rappole 1988), while others advocate keeping the genera separate (Outlaw et al. 2003). Some have suggested including it in Turdus, based on physiological and behavioral similarities to the American Robin (Dorst 1950, Bourns 1967). All four species are similar in behavior, anatomy, and breeding phenology, and with the exception of the American Robin, are fairly similar in appearance. All are primarily ground- and shrub-foraging insectivores and frugivores (Noon 1981, Moskoff 1995, Roth et al. 1996, Witmer 1998) that share considerable overlap in geographical range, nest site characteristics (Holmes et al. 1979, Johnston 1943, Gross 1949, Tozer 1997), and habitat requirements (Dilger 1956a, b, Noon 1981, Paszkowski 1984).

Because the four species share common traits and behaviors while nesting in close proximity to one another, they may compete for nesting sites or other resources. American Robins are known to defend fruit supplies from other species (Pietz and Pietz 1987) and anecdotal observations of interspecific agonistic behaviors among the Catharus and Wood 
Thrush have been published (Dilger 1956b, Morse 1971), indicating that at least some level of competition may occur. Sensu Morse $(1971,1974)$, the Wood Thrush is socially dominant to the Veery and Hermit Thrush, and Noon (1981) concluded that in Vermont the range of the Veery is constrained by the Hermit Thrush. In West Virginia, Hall (1983) suggested, based on his observations, that interspecific tension exists among thrushes at higher elevations where the smaller Hermit Thrush is often "squeezed out" by the Veery at the lower edge of its altitudinal range. He also noted that in West Virginia the Veery and Hermit Thrush populations seem to oscillate in abundance with the Wood Thrush, but was unsure which species initiates these cycles in relative abundance.

Despite the above observations, few agonistic interactions actually have been observed where thrush territories occur together (Raitt and Hardy 1970, Bertin 1977, Noon 1981, Holmes and Robinson 1988), and responses to playbacks of the songs of other Catharus species were described as "weak" (Dilger 1956b, Noon 1981). Furthermore, because thrushes have been sympatric for some time, it is more likely that, having experienced competition in the past, they currently minimize or even avoid it by a phenomenon known as habitat partitioning (Rosenzweig 1981, 1987). The behavior of segregating available habitats as a means to minimize interspecific competition was suggested by Lack (1944) and Hardin (1960), and has been observed in various bird communities. For example warblers forage in different levels of the forest canopy (MacArthur 1958) and passerine species partition their territories according to habitat variables in Arkansas (James 1971) and the Virgin River Valley (Whitmore 1977).

Habitat partitioning also may benefit thrushes is by reducing the incidence of nest predation, a phenomenon which is often the primary cause of nest failure in songbirds (Martin 1993). Although an individual of a colonial nesting species may derive a measure of protection 
from nesting in an area with a high density of similar-looking nests (Hamilton 1971, Brown et al. 1990), forest songbirds that rely on concealment of their nests by surrounding vegetation and cryptic behavior at the nest site to minimize nest predation do not benefit from having a nest that looks similar to those of its neighbors. The reason for this disadvantage is that a predator tends to form a search image for key visual characteristics of the prey item it encounters most frequently (Tinbergen 1960, Pietrewicz and Kamil 1979). Avian predators such as crows also remember locations of songbird nests (Sonerud and Fjeld 1987) and perform area-restricted searches for prey. This method of foraging takes place around an area where an initial prey item was found, and is restricted to the initial prey type found there (Tinbergen et al. 1967), which can include a specific type of nest (Marzluff and Balda 1992). Thus, a predator is more likely to form a search image for similar-looking nests, especially where the nests occur in high densities (Tinbergen et al. 1967). Martin $(1988,1996)$ presented evidence for the hypothesis that dissimilar songbird nests have higher survival by demonstrating that predation rates were reduced when nests were partitioned among sites (Martin 1988), and that individual birds whose nest sites were similar to those of sympatric species were depredated more often than were those of individuals whose nest sites differed from sympatric species (Martin 1996).

If habitat partitioning is indeed the mechanism by which thrushes avoid competition for nest sites and/or decrease nest predation rates, there should be quantifiable differences in the habitats used by each species. Wood Thrush and Veery are considered area-sensitive, forest interior dwelling species (Heckert 1995, Robbins et al. 1989), and their breeding habitats generally have been characterized as closed-canopy deciduous or mixed forest (Moskoff 1995, Roth et al. 1996). Canopy closure is so strongly associated with Wood Thrush habitat that one author even suggested sunlight may hurt the Wood Thrush's large eyes, causing it to seek out the 
deep forest (Weaver 1949). The Veery also is associated with deciduous or mixed forest, but differs from the Wood Thrush by often being found in areas of higher shrub density (Beals 1960, Bertin 1977, Noon 1981, Moskoff 1995, Roth et al. 1996, Heckscher 2004). Soil moisture has been cited as separating the habitats of the Wood Thrush, Veery, and Hermit Thrush, with the Veery said to inhabit the dampest areas (Morse 1971, Bertin 1977), the Wood Thrush in mesic sites, and the Hermit Thrush the driest (Morse 1971). The Hermit Thrush does occur in dry pineoak forests (Morse 1971), but also at the edges of spruce bogs (Hall 1983) and in other moist locations (Jones and Donovan 1996). In some areas, elevation has been cited as the primary partitioning variable among the guild (Noon 1981). In West Virginia, the Hermit Thrush is most abundant in the high elevation red spruce (Picea abies) or spruce-northern hardwoods forest, the Veery at middle elevations, and the American Robin and Wood Thrush are common throughout the state (Hall 1983, 1984, Buckelew and Hall 1994). The American Robin is considered a generalist species (Sallabanks and James 1999), and will nest wherever there are at least a few trees and some grass present, including urban areas (Buckelew and Hall 1984). The Wood Thrush also will nest near human habitation (Roth et al. 1996) and the Hermit Thrush near disturbances such as sites of logging, drilling, or road-building (Dilger 1956a, 1956b, Martin 1960, Aldrich 1968, Hall 1983, Peck and James 1987). Nest height is another difference among the species, with the Veery and Hermit Thrush nesting on or near the ground (Moskoff 1995, Jones and Donovan 1996) and the Wood Thrush and American Robin at variable heights within trees (Roth et al. 1996, Sallabanks and James 1999).

But despite the generalized habitat descriptions above, relatively few publications have dealt specifically with habitat partitioning in the thrush family. The specific differences among nest sites of the species remain unclear (Jones and Donovan 1996), especially in areas where two 
or more species nest in close proximity to one another (Noon 1981), or where the same territory is occupied by different species in different years (Morse 1971). Dilger's (1956a, 1956b) comprehensive studies investigated habitat partitioning among the Hermit Thrush, Veery, Swainson's Thrush (C. ustulatus), and Bicknell's Thrush (C. bicknelii) in terms of their morphology, foraging behavior, habitat characteristics, and agonistic interactions. Noon (1981) considered partitioning along elevational gradients in Vermont and also in The Great Smoky Mountains National Park in North Carolina and Tennessee. In Vermont the guild included the Hermit Thrush, Swainson's Thrush, Veery, and Wood Thrush, while in the Great Smoky Mountains only the latter two species were present. Morse (1971) examined the forest composition at locations in Maine where the Hermit Thrush, Veery, and Wood Thrush were detected, and observed their interspecific interactions. In a short communication, Morse (1972) also related the presence of Swainson's Thrushes and Hermit Thrushes to each other and to the percent coniferous foliage present on islands. Furthermore, based on the data collected in these two studies, Morse (1974) made predictions concerning social hierarchies within the guild. Bertin (1977) quantified habitat differences between the Wood Thrush and Veery in Connecticut, especially as they related to soil moisture and vegetation structure. Nixon et al. (2001) considered the co-occurrence of the Bicknell's Thrush and Swainson's thrush in New Brunswick, and Raitt and Hardy (1970) examined partitioning of two Central American species, C. occidentalis and C. frantzii, where they are sympatric in Mexico. Paszkowski (1984) identified differences in the foraging behavior of the Hermit Thrush and Veery in Wisconsin, and Sealy (1974) considered temporal partitioning by American Robin, Hermit Thrush, Swainson's Thrush, and Varied Thrush (Ixoreus naevius) in British Columbia. Only Sealy (1974) mentioned the American Robin as being a member of the guild; only Noon (1981) considered the 
phenomenon of habitat partitioning as it occurs south of New England; and none of the above studies monitored nest survival as part of their investigations.

The answer to the question of which specific nesting habitat characteristics are unique to each species may have important management implications for these forest dwelling birds in a landscape where timber harvesting occurs. The effects of timber harvesting on the distribution and nest survival of the thrush species individually have been fairly well documented (see Dellinger 2005, Ch. 3). But because harvesting alters the amount of forested habitat in each seral stage at the landscape scale, logging practices may affect where all four species occur together and how each species uses the habitat available for nesting. Thus, changes to the forest may have a direct relation with the guild of thrushes as a whole.

\section{Spatial SCALE}

Because nest site selection in birds is a hierarchical process that occurs on several spatial scales (Block and Brennan 1993, Jones 2001), and because the rate of nest predation also is affected by variables at different scales (Tarvin and Garvin 2002) I used the following frames of reference in this study: (1) nest substrate, (2) nest site, (3) territory, and (4) landscape. Although the region and continent may be the most important scales at which to examine avian demographics (Rosenberg et al. 1999, Baille et al. 2000), they were beyond the scope of my research.

Nest Substrate.-The nest substrate is the individual plant in which a bird builds its nest. In some bird species the substrate can serve as a proximate cue for nest-building behavior, based either on the plant species or on a component of physical structure, such as height, diameter, or density of foliage (Hughes 1977, Martin 1998). Most thrushes tend to place their large cup- 
shaped nests in a tree or shrub, although the Hermit Thrush and Veery also will nest directly on the ground (Moskoff 1995, Jones and Donovan 1996); and the American Robin and occasionally the Hermit Thrush will nest on man-made structures such as eaves or other ledges (Jones and Donovan 1996, Sallabanks and James 1999). The species of substrate used and the placement of the nest structure in relation to the ground, trunk, and surrounding branches can affect the nest's microclimate, a factor which in turn is related to egg viability, chick survival, and the amount of time the parents spend incubating the eggs (White and Kinney 1974, Weathers and Sullivan 1989, Conway and Martin 2000), and also contributes to the nest's visibility to and/or accessibility by predators (Martin and Roper 1988, Martin 1993). Logging activities could potentially affect the choice of substrates and the placement of nests within them by changing the size class structure of the forest and the relative abundance of tree species available for nesting.

Nest Site.-The nest site is the immediate area surrounding the nest substrate. It is conventionally characterized by a 0.04 ha circular plot centered on the nest (Martin et al. 1997), an appropriate scale for measuring microhabitat characteristics of small songbirds (Hunter 1990). The influence of characteristics at the nest site scale has been documented to influence nest predation rates by affecting how easily a predator can detect and access a nest (Martin 1992, Martin and Roper 1988). Furthermore, microhabitat variables have been found to distinguish the nest sites of some thrush species (Noon 1981).

Territory.-The breeding territory of a thrush ranges in size from $0.5-4.0$ ha (Howell 1942, Weaver 1949, Martin 1960, Bertin 1975, Pitts 1984). The characteristics of this area are important because once a male claims a territory, all subsequent breeding activities take place within it. He will sing and/or display to attract a female, build a nest, and meet the daily requirements of food and water for himself, his mate, and his nestlings. Thrush species may 
segregate themselves according to variables present at the territory scale such as basal area, tree and shrub density, canopy cover, canopy height, or ground cover (Noon 1981). For example, areas suitable for Wood Thrushes have been modeled using variables measurable at this scale such as elevation (Simons and Farnsworth 1996) and slope characteristics (Dettmers and Bart 1999).

Landscape.-I investigated the relation between changes to the landscape and the occurrence and nest survival of the four thrush species. The changes I examined were those caused by timber harvesting within the area of my study site. This approximately 5100 ha area was defined as the boundary of the landscape being investigated. While the study site was of course an arbitrary boundary in a biological sense, it was the scale at which forest management was implemented, and GIS data was not readily available for the private lands adjacent to it. Changes in the landscape surrounding a nest can have a greater influence on nest predation than do characteristics of a nest's microhabitat (Hoover et al. 1995). Furthermore, landscape variables pertaining to edge and fractal dimension explained variation in the abundance of Hermit Thrushes and American Robins (Hawrot and Niemi 1996), and Veeries and Wood Thrushes became progressively less frequent (Robbins et al. 1989) or experienced decreased breeding success as the size of forested areas decreased (Burke and Nol 1999).

\section{OBJECTIVES}

The overall purpose of this research was to quantify habitat partitioning and its relationship to nest survival by the American Robin, Hermit Thrush, Veery, and Wood Thrush, and furthermore to relate their occurrence and nest survival to features of a landscape impacted by logging activity. The specific objectives in my study of partitioning were to: 
1. quantify habitat partitioning at three spatial scales: (1) nest substrate, (2) nest site, and (3) territory; and

2. relate partitioned variables to nest survival.

To quantify the thrush species' use of a managed forest, my objectives were to:

3. determine the effect of land cover categories on species occurrence and nest survival; and to

4. determine if the occurrence and/or nest survival of each species changed as the proportion of each land cover at the study site changed over a three-year period.

Furthermore, to investigate whether the nest placement strategy of each species was the same in all land cover categories or if nests were placed differently, dependent upon the land cover, additional objectives were to:

5. describe differences among the land cover categories by quantifying the microhabitat variables present at random locations in each;

6. compare each nest's microhabitat with that of a random point within the surrounding stand;

7. compare the microhabitat characteristics of each species' nests across land cover categories; and

8. relate microhabitat characteristics to nest survival for each species.

\section{OVERVIEW OF CHAPTERS}

This dissertation has been written in the form of three chapters. The first chapter provides justification for and gives an overview of my research. The second chapter examines differences among the nesting habitat of thrushes and the effect of those differences on nest 
survival. The third chapter relates thrush occurrence and nest survival to forest management activities by evaluating differences in thrush use of land covers, and further examines the land covers at the microhabitat scale. The first chapter is written in the style of The Auk. The last two chapters are written in the style of, and will be submitted to the following scientific journals:

Chapter 2-The Auk

Chapter 3-Forest Ecology and Management. 


\section{LITERATURE CITED}

ALDRICH, J. W. 1968. Population characteristics and nomenclature of the Hermit Thrush. Proceedings of the U.S. National Museum 124:1-33.

AMERICAN ORNITHOLOGISTS' UNION. 1957. Checklist of North American birds. $5^{\text {th }}$ ed. American Ornithologists' Union, Washington, D.C.

AMERICAN ORNITHOLOGISTS' UNION. 2004. Checklist of North American Birds, $7^{\text {th }}$ ed. http://www.aou.org/aou/birdlist.html\#furn.

Avise, J. C., J. C. PAtTon, And C. F. Aquadro. 1980. Evolutionary genetics of birds. I. Relationships among North American thrushes and allies. Auk 97:135-147.

Baille, S. R., W. J. Sutherland, S. N. Freeman, R. D. Gregory, and E. Paradis. 2000. Consequences of large-scale processes for the conservation of bird populations. Journal of Applied Ecology 37:88-102.

BEALS, E. 1960. Forest bird communities in the Apostle Islands of Wisconsin. Wilson Bulletin 72:156-181.

BERTIN, R. I. 1975. Factors influencing the distribution of the wood thrush and veery in western Connecticut woodland. M.S. thesis, University of Connecticut, Storrs.

BERTIN, R. I. 1977. Breeding habitats of the Wood Thrush and Veery. Condor 79:303-311.

Block, W. M., AND L. A. BrenNAN. 1993. The habitat concept in ornithology. Pp 35-91 in Current Ornithology, Vol. 11 (D. M. Power, Ed.).. Plenum Press, New York.

BouRns, T. K. R. 1967. Serological relationships among some North American thrushes. Canadian Journal of Zoology 45:97-99.

Brown, C. R., B. J. StutchBury, AND P. D. WALSh. 1990. Choice of colony size in birds. Trends in Ecology and Evolution. 5:398-403.

Buckelew, A. R., AND G. A. HALl. 1994. The West Virginia breeding bird atlas. University of Pittsburgh Press, Pittsburgh.

BURKE, D. M., AND E. NOL. 1999. Landscape and fragment size effects on reproductive success of forest-breeding birds in Ontario. Ecological Applications 10:1749-1761.

COnway, C. J., AND T. E. Martin. 2000. Evolution of passerine incubation behavior: influence of food, temperature, and nest predation. Evolution 54:670-685. 
DETTMERS. R., AND J. BART. 1999. A GIS modeling method applied to predicting forest songbird habitat. Ecological Applications 9:152-163.

DilgER, W. C. 1956a. Adaptive modification and ecological isolating mechanisms in the thrush genera Catharus and Hylocichla. Wilson Bulletin 68:171-199.

DILGER, W.C. 1956b. Hostile behavior and reproductive isolating mechanisms in the avian genera Catharus and Hylocichla. Auk 73:313-353.

DiLGER, W.C. 1956c. Relationships of the thrush genera Catharus and Hylocichla. Systematic Zoology 5:174-182.

DORST, J. 1950. Considerations systematiques sur les grives du genre Turdus. L'Oiseaux Revieu Francaise Ornitholigique 20:212-248.

Gross, A. O. 1949. Eastern Hermit Thrush. Pages 143-162 in Life histories of North American thrushes, kinglets, and their allies (A. C. Bent, Ed.). United States National Museum Bulletin 196, Washington D.C.

HALL, G. A. 1983. West Virginia birds. Carnegie Museum of Natural History, Pittsburgh.

HALL, G. A. 1984. A long-term bird population study in an Appalachian spruce forest. Wilson Bulletin 96: 228-240.

HAMILTON, W. D. 1971. Geometry for the selfish herd. Journal of Theoretical Biology 31:295311.

HARDIN, G. 1960. The competitive exclusion principle. Science 131:1292-1298.

HAWROT, R. Y., AND G. J. NIEMI. 1996. Effects of edge type and patch shape on avian communities in mixed conifer-hardwood forest. Auk 113:586-598.

HECKERT, J. R. 1995. Status and habitat area requirements of the Veery in Illinois. Auk 112:794797.

HeCKSCHER, C. M. 2004. Veery nest sites in a mid-Atlantic piedmont forest: vegetative physiognomy and use of alien shrubs. American Midland Naturalist 151:326-337.

HENDRICKSON, H. T, AND M. Yow. 1973. The relationships of the Wood Thrush (Hylocichla mustelina): some indications from the electrophoresis of blood proteins. Condor 75:301305.

Holmes, R. T, R. E. Bonney, And S. W. Pacala. 1979. Guild structure of the Hubbard Brook bird community: a multivariate approach. Ecology 60:512-520. 
Holmes, R. T., AND S. K. RoBINSON. 1988. Spatial patterns, foraging tactics, and diets of ground-foraging birds in a northern hardwoods forest. Wilson Bulletin 100:377-394.

Hoover, J. P., M. C. BRITTINGHAM, AND L. J. GOODRICH. 1995. Effects of forest patch size on nesting success of wood thrushes. Auk 112:146-155.

Howell, J. C. 1942. Notes on the nesting habits of the American Robin (Turdus migratorius L.). American Midland Naturalist 28:529-603

Hughes, C. A. 1977. Vegetation cover as a proximate and ultimate factor of nest site selection in the Wood Thrush (Hylocichla mustelina). M.S. thesis, University of Delaware.

HUNTER, M. L. JR. 1990. Wildlife, Forests, and forestry: principles of managing forests for biological diversity. Prentice-Hall, Englewood Cliffs, New Jersey

JAMES, F. C. 1971. Ordinations of habitat relationships among breeding birds. Wilson Bulletin $83: 215-236$.

JoHnStON, V. R. 1943. An ecological study of nesting birds in the vicinity of Boulder, Colorado. Condor 45:61-68.

JONES, J. 2001. Habitat selection studies in avian ecology: a critical review. Auk 118:557-562.

Jones, P. W., AND T. M. Donovan. 1996. Hermit Thrush (Catharus guttatus). In The Birds of North America, no. 261 (A. Poole and F. Gill, Eds.). Academy of Natural Sciences, Philadelphia, and American Ornithologists' Union, Washington, D.C.

LACK, D. 1944. Ecological aspects of species formation in passerine birds. Ibis 86:260-286.

MACARTHUR, R. H. 1958. Population ecology of some warblers of northeastern coniferous forests. Ecology 39:599-619.

MARTIN, N. D. 1960. An analysis of bird populations in relation to forest succession in Algonquin Provincial Park, Ontario. Ecology 41:126-240.

MARTIN, T. E. 1992. Breeding productivity considerations: what are the appropriate habitat features for management? Pages 455-473 in Ecology and Conservation of Neotropical Migrant Landbirds (J. M. Hagan III, and J. W. Johnston, Eds.). Smithsonian Institution Press, Washington, D.C.

MARTIN, T. E. 1993. Nest predation and nest sites: new perspectives on old patterns. BioScience 43:523-532.

MARTIN, T. E. 1996. Fitness costs of resource overlap among coexisting bird species. Nature 380:338-340. 
MARTIN, T. E. 1998. Are microhabitat preferences of coexisting species under selection and adaptive? Ecology 79:656-670.

Martin, T. E., C. Paine, C. H. Conway, W. M. HochachKa, P. Allen, And W.

JENKInS. 1997. BBIRD Field Protocol. USGS, Biological Resources Division, Montana Cooperative Fish and Wildlife Research Unit, Missoula, Montana. http://pica.wru.umt.edu/bbird/

MARTIN, T. E., AND J. J. RoPER. 1988. Nest predation and nest site selection in a western population of the Hermit Thrush. Condor 90:51-57.

MARZLUFF, J., AND R. BALDA. 1992. The Pinyon Jay: behavioral ecology of a colonial and cooperative corvid. Academic Press: San Diego, California.

MorSE, D. H. 1971. Effects of the arrival of a new species upon habitat utilization by two forest thrushes in Maine. Wilson Bulletin 83:57-65.

MoRSE, D. H. 1972. Habitat differences of Swainson's and Hermit thrushes. Wilson Bulletin 84(2):206-208.

Morse, D. H. 1974. Niche breadth as a function of social dominance. American Naturalist 108:818-830.

Moskoff, W. 1995. Veery (Catharus fuscescens). In The Birds of North America, no. 142 (A. Poole and F. Gill, Eds.). Academy of Natural Sciences, Philadelphia, and American Ornithologists' Union, Washington, D.C.

Nixon, E. A., S. B. Holmes, AND A. W. Diamond. 2001. Bicknell's Thrushes (Catharus bicknelli) in New Brunswick clear cuts: their habitat associations and co-occurrence with Swainson's Thrushes (Catharus ustulatus). Wilson Bulletin 113: 33-40.

NoON, B. R. 1981. The distribution of an avian guild along a temperate elevational gradient: the importance and expression of competition. Ecological Monographs 51:105-124.

Outlaw, D. C., G. Voelker, B. Mila, And D. J. GiRman. 2003. Evolution of long-distance migration in and historical biogeography of Catharus thrushes: a molecular phylogenetic approach. Auk 120:299-310.

PASZKOWSKI, C. A. 1984. Macrohabitat use, microhabitat use, and foraging behavior of the Hermit Thrush and Veery in a northern Wisconsin forest. Wilson Bulletin 96:286-292.

PECK, G., AND R. JAMES. 1987. Breeding birds of Ontario: nidiology and distribution. Vol. 2, Passerines. Ontario Museum Life Sciences Miscellaneous Publication, Toronto.

Pietrewicz, A. T., AND A. C. KAMIL. 1979. Search image formation in the blue jay Cyanocitta cristata. Science 204:1332-1333. 
PIETZ, M. A. J., AND P. J. PIETZ. 1987. American Robin defends fruit resources against Cedar Waxwings. Journal of Field Ornithology 58:442-444.

PITTS, T. D. 1984. Description of American Robin territories in northwest Tennessee. Migrant 55:1-6.

RAITT, R. J., AND J. W. HARDY. 1970. Relationships between two partly sympatric species of thrushes (Catharus) in Mexico. Auk 87:20-57.

RobBins, C. S, D. K. DAwson, AND B. A. Dowell. 1989. Habitat area requirements of breeding forest birds of the Middle Atlantic States. Wildlife Monographs 103:1-34.

Rosenberg, D. K., D. F. Desante, K. S. McKelvey, and J. Hines. 1999. Monitoring survival rates of Swainson's Thrush Catharus ustulatus at multiple spatial scales. Bird Study 46: S198-S208.

RosenzWeIG, M. L. 1981. A theory of habitat selection. Ecology 62:327-335.

RosenZWEIG, M. L. 1987. Habitat selection as a source of biological diversity. Evolutionary Ecology 1:315-330.

Roth, R. R, M. S. JOHNSON, AND T. J. UnDERWOOD. 1996. Wood Thrush (Hylocichla mustelina). In The Birds of North America, no. 246 (A. Poole and F. Gill, Eds.). Academy of Natural Sciences, Philadelphia, and American Ornithologists' Union, Washington, D.C.

SAllabANKS, R., AND F. C. JAMES. 1999. American Robin (Turdus migratorius). In The Birds of North America, no. 462 (A. Poole and F. Gill, Eds.). Academy of Natural Sciences, Philadelphia, and American Ornithologists' Union, Washington, D.C.

SEALY, S. G. 1974. Ecological segregation of Swainson's and Hermit Thrushes on Langara Island, British Columbia. Condor 76:350-351.

SimOns, T., AND G. FARnswOrTH. 1996. Evaluating Great Smoky Mountains National Park as a population source for Wood Thrush. 1995 Annual Report National Biological Survey, Raleigh, North Carolina.

SONERUd, G. A., AND P. E. FJELD. 1987. Long-term memory in egg predators: An experiment with a Hooded Crow. Ornis Scandinavica 18: 323-325.

TARVIn, K. A., AND M. C. GARVIN. 2002. Habitat and nesting success of Blue Jays (Cyanocitta cristata): importance of scale. Auk 119: 971-983.

TINBERGEN, L. 1960. The natural control of insects in pinewoods. 1. Factors influencing the intensity of predation by songbirds. Archives Néerlandaises de Zoologie 13:265-343. 
Tinbergen, N., M. IMPEKOVEn, AND D. FrAnCK. 1967. An experiment on spacing-out as a defence against predation. Behaviour 28: 307-321.

TOzER, R. 1997. Unusual nesting of the Hermit Thrush. Ontario Birds 15:77-78.

Weathers, W. W., AND K. A. Sullivan. 1989. Nest attentiveness and egg temperature in the Yellow-eyed Junco. Condor 91:628-633.

WeAver, F. G. 1949. Wood Thrush. Pages 101-123 in Life histories of North American thrushes, kinglets, and their allies (A. C. Bent, Ed.). United States National Museum Bulletin 196, Washington D.C.

White, F. N., AND J. L. KINNEY. 1974. Avian incubation. Science New Series 186: 107-115.

WhitMORE, R. C. 1977. Habitat partitioning in a community of passerine birds. Wilson Bulletin 89:253-265.

WinKER, K., AND J. H. RAPPOLE. 1988. The relationship between Hylocichla and Catharus (Turdidae). Auk 105:392-394.

WiTMER, M. C. 1998. Do seeds hinder digestive processing of fruit pulp? Implications for plant/frugivore mutualisms. Auk 115:319-326. 
CHAPTER 2

HABITAT PARTITIONING OF FOUR SYMPATRIC THRUSH SPECIES AT THREE SPATIAL SCALES ON A MANAGED FOREST IN WEST VIRGINIA 
ABSTRACT.-Four thrush species are sympatric in the central Appalachians: Veery (Catharus fuscescens), Hermit Thrush (Catharus guttatus), American Robin (Turdus migratorius) and Wood Thrush (Hylocichla mustelina). The four often nest in close proximity to one another, suggesting that habitat partitioning may have developed to minimize past interspecific competition. Our objectives were to determine which specific characteristics of nesting habitat are partitioned among the species and to evaluate the relation of these characteristics to nest survival. We monitored nests and sampled habitat variables at three spatial scales: nest substrate, nest site, and territory. MANOVA indicated a difference $(P<0.01)$ in the nest sites of all species and in each pair-wise species contrast. ANOVA and Fisher's Exact Tests detected differences $(P<0.05)$ among species in 21 of 36 variables measured. Classification tree analysis correctly classified nests by species at a rate better than would be expected at random. Habitat partitioning among the four thrush species occurred at all three scales sampled, and the most important partitioning variables were nest height, distance to edge, sapling density, and elevation. Wood Thrush was found in lower elevation, primarily closed-canopy forests; Veery was distinguished by nesting in the low shrub layer in areas of high sapling density; Hermit Thrush nested at the highest elevation and was the only species to nest on the ground, with some individuals displaying the uncommon behavior of nesting on boulders or in trees; and American Robin overlapped considerably with the other species at all three scales. Mayfield logistic regression found a positive relation $(P<0.05)$ between decreasing nest height and American Robin nest survival. Overall, nest survival was similar among the four thrush species examined and most of the variables we measured were unrelated to survival, suggesting habitats were successfully partitioned. 
KEY WorDS: American Robin, habitat partitioning, Hermit Thrush, Turdidae, Veery, Wood Thrush

FOUR SPECIES of thrushes are sympatric in the Allegheny Mountain region of West Virginia: American Robin (Turdus migratorius), Hermit Thrush (Catharus guttatus), Veery (Catharus fuscescens), and Wood Thrush (Hylocichla mustelina). The guild contains three additional members-Gray-cheeked (C. minimus), Bicknell's (C. bicknelii), and Swainson's $(C$. ustulatus) Thrushes - in the Northeastern United States, but the number of species becomes fewer as the Appalachians extend south (Noon 1981); in the central Appalachians ranges of the Veery and Hermit Thrush have a narrower southern projection along the mountains. The Hermit Thrush, especially, becomes more restricted to high elevation forests as it ranges further south. Management for these species is especially important here, where timber harvesting is a common forest disturbance. Although one or more thrush species may be able to exploit new seral stages created by regenerating forests, the other species' local distributions may be altered or diminished if they are forced to nest in smaller fragments of intact forest habitat where they may experience interspecific competition for nest sites and other resources (Hagan et al. 1996). Thus, a better understanding of the way these species partition the habitat available to them may be needed to assist in their management.

The four thrush species are similar in behavior, anatomy and breeding phenology, and with the exception of the American Robin, are fairly similar in appearance. All four are primarily ground and shrub foraging insectivores and frugivores (Noon 1981, Moskoff 1995, Roth et al. 1996, Witmer 1998) that share considerable overlap in the placement of their nest sites (Johnston 1943, Gross 1949, Holmes et al. 1979) and in their habitat requirements (Dilger 
1956a, 1956b, Paszkowski 1984). Because these species share common traits and behaviors while living sympatrically, it is likely that habitat partitioning has developed as a means to minimize past interspecific competition (Rosenzweig 1981, 1987), and/or decrease nest predation rates as exhibited by other songbird guilds (James 1971, Whitmore 1977). Specific differences among thrush nesting habitats appear to vary by region and are often described by variables such as soil moisture, forest type (Dilger 1956a, Dilger 1956b, Morse 1972, Roth et al. 1996), and forest age (Bertin 1977). Jones and Donovan (1996) admit the specific habitat differences of Wood Thrush and Catharus thrushes are "unclear", but suggest they may have to do with microhabitat preferences, interspecific competition, and/or breeding phenology. Other authors have investigated this phenomenon in the family Turdidae, but only Sealy (1974) mentioned the American Robin as being a member of the guild; only Noon (1981) considered the phenomenon of habitat partitioning as it occurs south of New England; and none have monitored nest survival as part of their investigations.

Objectives of our study were to quantify habitat partitioning by the American Robin, Hermit Thrush, Veery, and Wood Thrush in a managed, Central Appalachian forest where males of all four species were heard singing within the same 100-m radius, and nests of two or more species were found within $100 \mathrm{~m}$ of one another (Dellinger et al. 2004). We examined partitioning at three spatial scales: (1) nest substrate, (2) nest site, and (3) territory. In addition, to determine which habitat characteristics were most important to the successful reproduction of each species, we related partitioned variables to nest survival. 


\section{Methods}

Study area.- - Our study was conducted in the unglaciated Allegheny Mountain and Plateau region, in southwestern Randolph County, West Virginia at the MeadWestvaco Wildlife and Ecosystem Research Forest (MWERF) and the Panther Run Tract. The MWERF is a 3413 ha forested area, set aside in 1994 to study the ecological effects of forest management practices. The Panther Run tract, also owned by MeadWestvaco Corporation, is located $16 \mathrm{~km}$ to the north and has an area of approximately 1705 ha. The region's topography contains narrow valleys with high gradient streams, and steep slopes topped by broad ridges that run in a south-southwest to north-northeasterly direction.

Approximately $63 \%$ of the site consisted of intact, predominantly closed-canopy forest that received diameter limit cutting no more recently than the 1970's and 1980's, with stands originating in the 1920's (P. D. Keyser, MeadWestvaco Corporation, pers. comm.). The highest elevation mature forests $(>1000 \mathrm{~m}$ ) were characterized by mixed stands of northern hardwoods, red spruce (Picea rubens), and eastern hemlock (Tsuga canadensis). Middle elevations (850$1000 \mathrm{~m}$ ), were dominated by northern hardwoods such as red maple (Acer rubrum), sugar maple (A. saccharum), American beech (Fagus grandifolia), yellow birch (Betula allegheniensis), black cherry (Prunus serotina), and Fraser magnolia (Magnolia fraseri), with an understory of striped maple (A. pennsylvanicum). Below $850 \mathrm{~m}$, cove hardwood and mixed mesophytic plant communities consisted of northern red oak (Quercus rubra), white ash (Fraxinus americana), American basswood (Tilia americana), cucumber magnolia (Magnolia acuminata), black birch (Betula lenta), and tulip-poplar (Liriodendron tulipifera), with an understory of American beech and red maple. Xeric oak-hickory (Quercus-carya) communities also occurred at low elevations. Communities of eastern hemlock, red spruce and great rhododendron (Rhododendron maximum) 
occurred in the riparian areas surrounding streams, and a few small stands of mature white pine (Pinus strobes) covered reclaimed strip mines. Most mature forest areas had a fairly open understory, a greenbrier (Smilax spp.) shrub layer, and a dense ground cover of hay-scented fern (Dennstaedtia punctilobula), as a result of high rates of deer herbivory (Hicks 1998).

Approximately $10 \%$ of the site consisted of even-aged harvests, the oldest of which was nine years post-harvest. Regeneration in these stands consisted primarily of Rubus, fire cherry (Prunus pennsylvanica), and stump sprouts of black cherry, tulip-poplar, and red maple. An average of $24 \%$ of the site consisted of regenerating partial harvests that took place from 1990 to the present. Areas harvested since 2000 had fairly open understories similar to those of mature forest areas, while the understory layers of stands harvested in the early 1990's were typically very dense. At lower elevations this understory consisted primarily of spicebush (Lindera benzoin) and American beech saplings, and at middle elevations it consisted of a shrub layer of greenbrier. The remaining 5\% of the study site consisted of gravel and paved roads, wildlife food plots, streams, ponds, grassy to shrubby openings and roadsides, utility rights-of-way, and gas wells.

Nest searching and monitoring.-We searched for nests of the four thrush species within 18 20-ha plots distributed across study sites. All plots were oriented parallel to the slope, to reflect the steep nature of the landscape and to avoid being overly concentrated in either ridges or valleys. We also searched for nests near 162 point count stations where thrushes were detected as part of a concurrent study on forest songbirds during 2001-2003. These methods were used to systematize our search efforts and avoid finding only those nests that were most visually obvious. Nests were located using techniques summarized by Martin and Guepel (1993), 
including systematically searching likely areas, listening for begging chicks, and observing the behavior of adult birds.

We revisited the nests every two to three days to determine success at each developmental stage. Nests that fledged at least one chick were considered successful. Circumstantial evidence for a successful nest included observations of nestlings within two days of the average fledging age for the species (after Whitcomb et al. 1981 and Ehrlich et al. 1988), alterations to the nest structure indicative of fledging, observations of fledglings near the nest, or of parents with fledglings in the general vicinity of the nest. Evidence for a failed nest included signs of predation or disappearance of the nest, eggs, adults, or nestlings before the average age of fledging for the species. If insufficient evidence was found from which to draw a conclusion, the fate of the nest was recorded as unknown and the last exposure day was recorded as the last time activity was observed at the nest (Manolis et al. 2000).

Nest substrate sampling.- Using methods modified from BBIRD protocols (Martin et al. 1997), we sampled six variables (Table 1) to describe the placement of the nest structure within the individual plant selected by birds for nesting. These variables were: nest height, substrate height, substrate diameter, number of branches supporting the nest, average diameter of the supporting branches, and percent canopy cover above the nest.

Nest site sampling.-We sampled 21 variables (Table 1) within a 0.04-ha circular plot centered at each nest using methods modified from James and Shugart (1970) and BBIRD protocols (Martin et al. 1997). These variables were: average canopy height, distance to edge, percent slope, aspect, percent of the plot covered by each of six groundcover types (herbaceous, litter, woody debris, moss, water), percent of the plot covered by each of six canopy layers ( $0-3$ 
$\mathrm{m}, 3.1-6.0 \mathrm{~m}, 6.1-12.0 \mathrm{~m}, 12.1-18.0 \mathrm{~m}, 18.1-24.0 \mathrm{~m},>24.0 \mathrm{~m})$, number of stems in four diameter classes $(<7.6 \mathrm{~cm}, 7.6-22.9 \mathrm{~cm}, 23.0-38.0 \mathrm{~cm},>38.0 \mathrm{~cm})$, and number of snags.

Territory scale sampling.- - The territory scale was characterized within a 4.0-ha circular plot centered on each nest, and encompassed the 0.04-ha plot described above. This size plot was chosen as the maximum territory size reported for thrushes (Howell 1942, Weaver 1949, Martin 1960, Bertin 1975). Elevation, slope position, and aspect of the nest's location were determined using topographic maps. Elevation was determined to the nearest $20 \mathrm{~m}$ using contour lines on a topographic map. Slope position was recorded as low, middle or upper, according to the third of the slope on which each nest was located. Aspect of the slope from the top of the ridge to the bottom of the valley was measured using a map and a compass.

At nests monitored during the second two years of the study, we recorded the presence of the following features within a 4.0-ha plot: even-aged regeneration harvests $<9$ years old, water, skid trails, roads (paved and dirt), grassy areas (gas wells, wildlife plantings, and log landings), and man-made structures such as gas wells and buildings. We found these features by searching the area systematically and then confirming their locations by inspecting aerial photographs, a technique that significantly reduces errors of omission in locating canopy gaps (Fox et al. 2000). Systematic searches were accomplished by walking eight evenly spaced azimuths radiating out from each nest for $113 \mathrm{~m}$. The first azimuth was chosen from a random number table, and the remaining seven by adding $45^{\circ}$ to the first and each subsequent azimuth.

\section{STATISTICAL ANALYSES}

We considered our experimental unit to be each individual nest we monitored, assuming that a separate breeding pair of thrushes built each nest. Analyses were performed separately for 
each of three spatial scales sampled. Because it has been suggested that $>20$ nests of a species are considered necessary to conduct meaningful between-species comparisons (Nur et al. 1999), nests were combined for the three years of data collection and habitat data were not compared among years. All variables representing densities were transformed using a square root transformation, and variables representing percents were transformed by taking the square root, then finding the inverse sine (arcsine) of the resulting number. To aid in its interpretation, the value of the variable aspect was transformed with the Beers et al. (1966) transformation: $\mathrm{A}^{\prime}=$ $\cos (45-\mathrm{A})+1$. Values can range from $0-2$, with 2 indicating northeast facing slopes and 0 indicating southwest facing slopes (Beers et al. 1966). For all analyses, $\alpha$ was set at 0.05 . Nest substrate variables. - We conducted a one-way multivariate analysis of variance (MANOVA, SAS ${ }^{\circledR}$ Institute 2004) and post-hoc pair-wise contrasts (Barker and Barker 1984) on nest substrate variables to detect differences in the overall microhabitat within the nest substrate of the remaining three species. A one-way analysis of variance (ANOVA, Dowdy and Wearden 1983 ) with post-hoc comparisons using the Waller-Duncan k-ratio $t$-test (SAS ${ }^{\circledR}$ Institute 2004) identified the specific variables that differed among species. For both multivariate and univariate analyses of variance, thrush species was the independent variable and the dependent variables were substrate height, diameter of substrate, number of supporting branches, average diameter of supporting branches, nest height, and percent canopy cover. All univariate and multivariate analyses of variance were performed using $\mathrm{SAS}^{\odot}$ Version 8.1 statistical software $\left(\mathrm{SAS}^{\circledR}\right.$ Institute 2004).

A classification tree analysis using $\mathrm{R}^{\odot}$ software ( $\mathrm{R}$ Development Core Team 2004) was used to determine which nest substrate variables were most important in habitat partitioning among the species. Classification tree analysis is a non-parametric binary recursive partitioning 
procedure (Breiman et al. 1984, Clark and Pregibon 1992) that is increasingly being applied to ecological research (Karels et al. 2004, O'Connor and Wagner 2004, Rejwan et al. 1999). The technique consists of dividing the data through a series of binary splits in multi-dimensional space using each variable in turn as a possible predictor. At each split the choice is made that maximizes the separation of values between the two subsets of data generated by the split and a classification tree is generated. The same assessment is then repeated with each of the two created groups and each variable is again assessed regardless of whether it was used previously in the construction of the tree. The splitting continues until there is one data point in each terminal group, or all data points belong to the same class (species), or the tree has reached a predetermined size where splitting is halted. The size of the classification tree is measured by the number of final groups, or leaves, in the tree; thus in our study the original, undivided data set would have a tree size of one, and the ideal size would be four, with a final leaf for each thrush species.

Because the classification tree procedure is non-parametric, we used untransformed data for analysis. We pruned our trees using ten-fold cross-validation, a technique to optimize tree size and lower the complexity parameter and estimated error rate (Breiman et al. 1984). Using this technique, the data were divided into ten approximately equal sized subsets, and one sub-set at a time was then dropped out and a tree constructed using the remaining nine sets. The error of each tree was then determined by testing it with the excluded sub-set. From the possible trees, the one was selected that had a tree size closest to four with the smallest possible estimated error rate.

Once the classification tree was created and pruned using the cross-validation procedure, we determined to what degree the pruned tree explained more variance than would a random 
classification tree of equal complexity. We determined its ability to classify nests by calculating $\mathrm{K}$, which is equal to the ratio of the amount the model improves classification to what would be expected if observations were assigned to categories at random. For example, there were 141 observations (nests) and four categories (thrush species); random assignment of observations to categories would result, on average, in $141(1 / 4)=35.25$ correctly classified observations. If the classification tree correctly classified 99 observations, this tree would be an improvement over random classification of $99-35.25=63.75$ correct observations. If, however, the tree classified all observations perfectly, there would be an improvement of $141-35.25=105.75$ observations. $\mathrm{K}$ is the ratio of these two numbers, such that $\mathrm{K}=63.75 / 105.75=0.6028$. A similar measure of the explanatory value of the classifications generated by discriminant function analysis has been described by Titus et al. (1984) and been applied by other authors to discriminant function analysis in the study of avian nesting (Murphy et al. 1997, Clark and Shutler 1999).

The relative contributions of each variable were determined by calculating a measure of the reduction in diversity, calculated by the formula diversity $=\sum\left\{n_{i}\left(\log p_{i}\right)\right\}$, (Breiman et al. 1984) where $n=$ the number of nests belonging to species $i$ and $p=$ the proportion of nests belonging to species $i$. For the classification scheme at each scale, this formula was calculated for all species in each leaf at each split, and the values summed within and across leaves to obtain the total diversity at each step. The reduction in diversity then was obtained by subtraction.

Nest site variables. - The above procedures for nesting substrate variables also were used to analyze nest site variables. The dependent variables used in univariate and multivariate analyses of variance were the 21 habitat variables sample at this scale (Table 1). 
Territory-scale variables-ANOVA (Dowdy and Wearden 1983) was used to determine if mean elevation and aspect of the territory scale differed among species. Slope position was compared among species using a Fisher's Exact Test $\left(\mathrm{SAS}^{\circledR}\right.$ Institute 2004). Fisher's Exact Test also was used to test whether the percent of nests with six habitat features (Table 1) present or absent within a 4.0 ha plot differed among species. Classification tree analysis is robust to data with missing values, therefore this analysis included all nests of all species and was performed as described above using all continuous and categorical territory-scale variables.

Relation of variables to nesting success.-Nests were monitored on the 18 nest-searching plots as well as outside the plots. The Mayfield method (Mayfield 1961, 1975) was used to calculate daily survival rates for each species. Daily survival estimates were calculated for the incubation and brooding periods separately because there may be differential survival between these two periods. Total survival for the whole nest cycle was the product of survival during the incubation and brooding periods.

Survival was compared between on and off-plot nests, and among years using CONTRAST $^{\odot}$ software (Hines and Sauer 1989). The small number of nests found in 2001 precluded a comparison with other years for each species individually, but species-specific nest survival did not differ between 2002 and 2003 and no differences were found among years for all species combined. Survival rates of nests of each species found within designated nest-searching plots and those found elsewhere also did not differ. Because survival was similar on and offplots and among years, we pooled all data within each species.

A separate "Mayfield logistic regression" model was constructed using the methods of Hazler (2004) for each species at each of the three spatial scales sampled. The dependent variable in each model was the Mayfield estimator of nest survival for that species (Mayfield 
1961, 1975) expressed in SAS ${ }^{\circledR}$ (SAS $^{\circledR}$ Institute 2004) as FAILURE / DAYS OBSERVED (Hazler 2004) where FAILURE was a binary variable and DAYS OBSERVED was the number of days the nest was monitored. Independent variables initially used in the models were those habitat variables identified by the classification tree procedure as maximizing species separation at each spatial scale. We used the stepwise procedure (SAS ${ }^{\circledR}$ Institute 2004) to determine which variables were related to survival, and the Wald $\chi^{2}$ test to test for their significance. The model Goodness-of-Fit $\chi 2$ test $\left(G_{\mathrm{M}}\right)$ (Hosmer and Lemeshow 1989) was used to test the model's fit to the data. An $\alpha$ level of 0.15 was chosen to enter and keep variables in the model during the stepwise procedure. This approach to selecting variables for the models was chosen in an effort to determine whether variables that contribute to partitioning among the species also are related to nest survival. Hypothetically, greater partitioning should result in greater nest survival, and those variables that contribute to partitioning should be the most related to nest survival (Martin 1988). This prediction is based on the mechanism by which a predator forms a search image for key visual characteristics of the prey item it encounters most frequently (Tinbergen 1960, Pietrewicz and Kamil 1979); thus, a predator is more likely to form a search image for similarlooking nests. Martin $(1988,1996)$ presented evidence for this hypothesis using songbird nests by demonstrating that predation rates were reduced when nests were partitioned among sites (Martin 1988), and that individual birds whose nest sites were similar to those of sympatric species were depredated more often than were those of individuals whose nest sites differed from sympatric species (Martin 1996). 


\section{REsults}

Nest monitoring.- - One hundred forty-one nests were found and monitored: 17 American Robin, 28 Hermit Thrush, 46 Veery, and 50 Wood Thrush. Ninety were monitored within designated nest-searching plots and 51 were monitored outside the plots, found either during searches near point count stations or found incidentally.

Habitat partitioning at the nest substrate scale.-Nest substrate variables were measured at 117 nests: 16 American Robin, 5 Hermit Thrush, 46 Veery, and 50 Wood Thrush. Three variables (number of supporting branches, average diameter of supporting branches, and percent canopy cover above nest) were not measurable at one American Robin nest due to its height of $20 \mathrm{~m}$. Additionally, variables at this scale were not applicable to the majority of Hermit Thrush nests we monitored $(n=23)$ that were located on the ground. Although five Hermit Thrush nests were located in trees, the small number of such nests $(n=5)$ precluded their inclusion in statistical analysis at this scale. MANOVA detected a significant difference (Wilk's $\lambda=0.26, \mathrm{~F}$ $=16.87, P<0.01)$ in the overall microhabitats among the three species analyzed at this level, and post-hoc contrasts found pair-wise differences in all species combinations $(P<0.01)$ (Table 2$)$. ANOVA indicated that all six individual variables differed $(P<0.05)$ among species (Table 3$)$.

Classification tree analysis resulted in a tree that separated Wood Thrush and Veery nests by nest height; nests $\geq 1.6 \mathrm{~m}$ in height were classified as Wood Thrush and those $\leq 1.6 \mathrm{~m}$ were classified as Veery. American Robin nests could not be differentiated using variables at this scale, thus the tree had only two terminal groups (Fig. 1). Ninety-eight percent of Wood Thrush and $96 \%$ of Veery nests were classified correctly using the ten-fold cross validation method with this tree, but all American Robin nests were misclassified as either Wood Thrush or Veery 
(Table 4). Classification of nests at the substrate scale resulted in a higher value of $K(K=0.73)$ than did classification based on the nest site $(K=0.58)$ or landscape $(K=0.60)$ scales (Table 4$)$.

Habitat partitioning at the nest site scale.-Nest site variables were measured at all 141 nests. MANOVA detected a significant difference (Wilk's $\lambda=0.22, \mathrm{~F}=3.64, P<0.01$ ) in the overall nest sites among species, and post-hoc contrasts found pair-wise differences in all species combinations $(P<0.01)$ (Table 2). Thirteen of 21 individual variables differed $(P<0.05)$ among species (Table 3).

Classification tree analysis generated a tree with six terminal groups, one each for American Robin, Hermit Thrush and Wood Thrush, indicating good separation of these species at the nest site scale; there were, however, three terminal groups generated for Veery, reflecting its overlap in nest site characteristics with the Wood Thrush (Fig. 2). Forty-seven percent of American Robin nests, $46 \%$ of Hermit Thrush nests, $78 \%$ of Veery and $80 \%$ of Wood Thrush nests were classified correctly using the ten-fold cross-validation method with this tree (Table 4). Classification at the nest site scale resulted in the lowest value of $\mathrm{K}$ among the three scales.

Distance to edge was the most important variable used in nest site classification (reduction in diversity $=42.4)($ Table 5). This variable separated American Robins and Hermit Thrushes — which tended to nest near roads and skid trails—-from Veeries and Wood Thrushes, which placed their nests at a greater distance from edges. The remaining variables did not have large diversity reduction scores, and thus had limited usefulness in separating the species. Based on these remaining variables, American Robin and Hermit Thrush nests sites were separated by American robins having fewer medium-sized trees present, and Veery and Wood Thrush nest sites were separated by the latter species having more woody debris groundcover, fewer saplings, and more canopy cover above the nest. 
Habitat partitioning at the territory scale.-Elevation, slope position, and aspect were measured for all 141 nests; the presence or absence of six habitat features was measured for 119 nests (Table 6). Mean elevation differed among species $(\mathrm{F}=44.88, P<0.01)$ (Table 3$)$, with Hermit Thrush nest sites located at the highest mean elevation, American Robin and Veery nest sites at similar, intermediate elevations, and Wood Thrush nests at the lowest elevations. The range of elevation at which nests were placed overlapped among all four species such that no two species were completely isolated by this variable except for Wood Thrushes at the lower extreme of their range $(<878 \mathrm{~m})$ and Hermit Thrushes at the higher extreme of theirs $(>1000 \mathrm{~m})$ (Table 3). Aspect $(\mathrm{F}=3.72, P=0.01)$ differed among species, with Veery territories located on slightly less north-easterly facing sites than Hermit Thrush and Wood Thrush. Slope position differed among species overall $(P<0.01)$ and for each pair-wise comparison $(P<0.05)$ except between Wood Thrush and Veery (Table 6). Hermit Thrushes tended to nest on upper and lower slopes and American Robins on mid-slopes, while Veery and Wood Thrush nests were more evenly distributed among slope positions. Presence or absence of skid trails $(P=0.61)$, roads $(P=$ 0.99), even-aged harvests $(P=0.88)$, water $(P=0.18)$, grass $(P=0.81)$, and development $(P=$ 0.50) did not differ among species.

Classification tree analysis generated a tree with seven terminal groups and an intermediate value of K (Fig. 3). The most important variables used as splitting criteria were: elevation of $847 \mathrm{~m}$, slope position, and elevation of $1030 \mathrm{~m}$ (Table 5). Only 35\% of American Robin nests, however, were correctly classified using the ten-fold validation of the tree (Table 4), suggesting that their nests could not be distinguished from the other three species based on territory-level variables alone. The other three species had higher rates of correct classification: $93 \%$ of Hermit Thrush, $61 \%$ of Veery, and $78 \%$ of Wood Thrush nests were classified correctly. 
Relation of variables to nest survival. - We were able to determine fate of 128 of 141 nests monitored. Nest survival was similar among species, ranging from $24 \%$ for Wood Thrushes to 39\% for American Robins (Table 8). Of twelve logistic regression models constructed, one yielded variables significantly associated with nest survival. Increasing nest height was negatively associated with nest survival of the American Robin at the substrate scale $\left(B_{o}=-0.59, \mathrm{SE}=0.23\right.$, Wald $\left.\chi^{2}=8.49, P=0.01\right)$; however, the fit of the model to the data was somewhat questionable $\left(G_{\mathrm{M}}=15.32\right.$, d.f. $\left.=8, P=0.05\right)$.

\section{DISCUSSION}

Wood Thrush.-At the largest scale, elevation was the key partitioning variable between the Wood Thrush and Hermit Thrush, a result similar to Noon's (1981), who found elevation to be the primary variable separating five thrush species in Vermont. In this study, $75 \%$ of Wood Thrush nests were located between $634-847 \mathrm{~m}$, and the species was never detected above 1000 m. The elevational limit for Wood Thrushes in West Virginia is reported to be the highest elevation of deciduous forest (Hall 1983). Hermit Thrush nests were observed at elevations from 878-1109 $\mathrm{m}$, allowing for only a small area of overlap between the two species at the upper end of the Wood Thrush's altitudinal range. The other two species had wider ranges, with American Robin nests found from 744-1061 m and Veery nests from 622-1097 m. In Vermont, the Wood Thrush and Veery shared the same upper limit and the Hermit Thrush had the largest elevational range. In the Great Smoky Mountains National Park, where only the Wood Thrush and Veery are present, the two had little overlap (Noon 1981).

At a smaller scale, Wood Thrush nest sites possessed many characteristics previously described, such as a sapling understory (Dilger 1956a), at least one tree $>12 \mathrm{~m}$ in height (Bertin 
1977), and fairly complete canopy closure (Crawford et al. 1981, Hall 1983). Similar to the findings of Noon (1981), Wood Thrush nest sites had the greatest overlap with those of the Veery, as reflected by the fact that they were most often misclassified as each other. Both species were located farther from edges than the other two thrushes, and in forested areas where ground cover was predominantly leaf litter and woody debris. Factors that distinguished nest sites of the Wood Thrush from those of the Veery were a greater amount of canopy cover, especially by mature overstory trees and saplings $<6 \mathrm{~m}$ in height.

Fifty-eight percent of Wood Thrush and $46 \%$ of Veery nests monitored were in American beech trees; however, nests of the two species were distinguished easily by nest height. Veery nests were placed lower, in dense beech root sprouts or epicormic branches, while Wood Thrush nests were placed higher, usually in the main crotch of a beech sapling. Although it is not clear from our data whether the Wood Thrush and Veery actually selected beech for nesting or if they simply used the species in proportion to its availability at the study site, the dense saplings and epicormic branching typical of beeches created nesting opportunities at heights suitable for both species. Thus, the presence of American beech has potential value for the coexistence of the Veery and Wood Thrush within a stand.

Veery.-Veery nests were set apart from those of the other species by their low placement in short woody vegetation with many small branches available to support the nest structure. Although the Veery has been described elsewhere as a ground-nester (Moskoff 1995), all nests monitored in the present study were placed in low shrubs, saplings, epicormic tree branches, or stump sprouts, and ground nesting was not observed. It was the only species of the four to nest in Smilax, Rubus, Spirea or Rosa. Our observations are similar to those of Heckscher (2004), who found Veeries to nest predominantly in Rosa multiflora and to others 
who have confirmed the Veery's presence in areas of high shrub stem density (Beals 1960, Bertin 1977, Noon 1981, Roth et al. 1996). Noon (1981) and Paszkowski (1984) concluded that the shrubs served as foraging perches for the Veery; this interpretation, however, does not take into account the placement of the Veery nest structure within the shrubs. We suggest that the higher soil moisture reported by other authors at Veery nest sites (Morse 1971, Bertin 1977, Moskoff 1995) is a by-product of the Veery's preference for nesting within shrubs, which often grow along riparian areas in forests with an otherwise open understory. At our study site, Veery nests were not associated with the presence of water as reported by Bertin (1977) or with values of aspect and slope commonly indicative of high soil moisture, but instead with high stem density. However, our study site as a whole was predominantly mesic, with streams distributed throughout. Thus, although some dry ridge tops and damp cove areas were present, there was not a range of moisture regimes present in adequate amounts to fully test the role of soil moisture in partitioning.

Hermit Thrush.- Hermit Thrushes nested at the highest mean elevation, with a range of 878-1109 m. This altitudinal range was almost completely within that of the American Robin and Veery, but had a narrower range of overlap with the Wood Thrush, which was never observed above $1000 \mathrm{~m}$. Although the lowest Hermit Thrush nest monitored was at $878 \mathrm{~m}$, singing males were observed at elevations as low as $643 \mathrm{~m}$. This altitudinal range is much lower than that reported by Hall (1983), who observed them in West Virginia primarily above $1200 \mathrm{~m}$ and not below $1050 \mathrm{~m}$. Hermit Thrush nest sites had less woody debris and more moss groundcover than the other three species, and, similar to the finding of Noon (1981), fewer woody stems $<3 \mathrm{~m}$ in height. 
Hermit Thrushes showed two distinct nesting strategies: ground nests $(n=23)$ and tree nests $(n=5)$. Ground nests are typical of the eastern subspecies (C. g. faxoni) (Jones and Donovan 1996), and were unique to Hermit Thrushes among the four thrush species. Ten of the ground nests were located on open-canopy skidder trails revegetated with native Muhlenbergia or seeded grasses such as orchard (Dactylis glomerata) and panic (Dichanthalium) grasses, and often on the side of a constructed water-break. Apparently these remnants of past logging activities met the criteria of an interior edge reportedly favored by the species (Dilger 1956a). Nine nests also were located near the forest edge, but on banks of open-canopy roads. Three ground nests were located in closed-canopy forested areas with a groundcover consisting primarily of leaf litter and Lycopodium, similar to those described by Flaspohler and Temple (2000). One nest was located in a similar area, but atop a large boulder. At least two other abandoned nests were found in similar situations; and although they could not be confirmed as belonging to Hermit Thrushes, their presence suggests the use of large rocks as nesting substrate may not be totally anomalous. Such nests have occasionally been reported elsewhere (DeMeritte 1920). The majority of ground nests were located at the base of a fern or woody seedling and partially concealed by overhanging herbaceous vegetation.

Of the Hermit Thrush nests placed in trees, four were in red spruce and one was in a red maple sapling partially supported by an eastern hemlock. The use of small red spruce trees as a nesting substrate was similar to the nest placement of six American Robin nests located above $915 \mathrm{~m}$ in areas where regenerating spruce was present as a result of exposed mineral soil from past road construction and logging activity. Both species placed their nests from $0.3-1.8 \mathrm{~m}$ above the ground on two to six supporting branches directly against the trunk of small spruces approximately 2-4 $\mathrm{m}$ in height. It is unclear why Hermit Thrushes would choose a nesting 
strategy already being employed by a similar species if ground nesting were available to them; what effect this strategy had on nest survival also is unclear due to the small sample size of treenesters.

Tree nesting is a strategy more common of the western subspecies, C. g. auduboni (Gross 1949, Jones and Donovan 1996). Martin and Roper (1988) found western Hermit Thrushes to nest in small fir trees, and to select nest sites with proportionately more small firs than were available in randomly chosen sites. Tree nesting by eastern birds has been reported in Pennsylvania (Todd 1940, Gross 1949) and more recently in New York (Baird 2004). The reasons for the expansion of the Hermit Thrush's range southward through the high elevations of the Appalachian Mountains (McNair 1987, Knight 1997) are not understood, but the phenomenon appears to be limited to areas with spruce cover, and thus could possibly be related to the disposition of some individuals to nest in conifers. Although West Virginia is part of the Hermit Thrush's historical range, Hall (1984) noticed an increased presence of Hermit Thrushes in high elevation spruce and spruce-fir forest types where the species once was rare or mostly absent.

American Robin.-Most American Robin nests monitored were similar to Wood Thrush nests in their use of substrate and placement of the nest within a tree. Some individual American Robins, however, also placed their nests in situations similar to the other two thrush species. For example, individual nests could be found in shrubby areas, similar to Veeries, and in small, regenerating red spruces similar to the manner of tree-nesting Hermit Thrushes. Thus differences detected by MANOVA and ANOVA in overall habitat between robins and the other three species may be by-products of averaging nest habitat characteristics over a variety of nesting situations; were the sample of robin nests large enough to be sub-divided by 
characteristics such as nesting substrate, nest height, and canopy cover, there may have been more direct overlap detected with each of the other species according to the situation in which each individual robin nested. This overlap was well reflected by the inability of the classification tree analysis to generate a terminal group in which an American Robin nest was differentiated from the Wood Thrush or Veery.

Nest survival.—Nest survival rates of all four species fell within the range of, or surpassed, those reported for eastern forests by other published studies of nest survival that used the Mayfield method. These ranges in nest survival were: $20-60 \%$ for the American Robin, 1029\% for the Hermit Thrush, 14-74\% for the Veery, and 21-54\% for the Wood Thrush (Burke and Nol 2000, Dececco et al. 2000, Duguay et al. 2001, Martin et al. 2004). Mayfield logistic regression models identified nest height to be inversely related to survival for the American Robin. However, we found nest survival to be similar among the four thrush species and most of the variables we measured to have no relation to survival. Similarity in nest survival rates may indicate that the thrushes are partitioning the available habitat in a way that is mutually beneficial, and that the intensity of forest disturbance due to logging activity on the study site has not significantly disrupted this mechanism. It is possible, also, that logging may have enhanced the ability of thrushes to partition their nests by increasing the number of potential niches available; for example, nest sites in dense sapling stands, small spruce trees, and on roadside banks were made available by forest management activities. However, we did not measure the availability of nest sites, so we could not determine if nest site availability was a driving factor in habitat use or nest survival. Nest survival instead may have been related to unknown variables such as defensive behavior by parents or aspects of the predator community at the study site. 
In summary, partitioning occurred at all three scales examined. At the nest substrate scale, nest height separated Wood Thrush and Veery; at the nest site, distance to edge separated American Robin and Hermit Thrush from Wood Thrush and Veery; and at the territory scale, elevation separated Hermit Thrush from Wood Thrush. Wood Thrush was found primarily in lower elevation closed-canopy forests; Veery was distinguished by nesting in the low shrub layer in areas of high sapling density; Hermit Thrush nested at the highest elevation and was the only species to nest on the ground or boulders, with some individuals displaying the uncommon behavior of nesting in trees; and American Robin overlapped considerably with the other species at all three scales. Segregation of the species may have less to do with soil moisture than presumed by other authors.

\section{LITERATURE CitED}

BAIRD, T. H. 2004. An unusual Hermit Thrush nest in Cattaraugus County, New York. Kingbird 54:198-2000.

BARKER, H. R., AND B. M. BARKER. 1984. Multivariate analysis of variance (MANOVA): a practical guide to its use in scientific decision making. University of Alabama Press, Birmingham.

BEALS, E. 1960. Forest bird communities in the Apostle Islands of Wisconsin: Wilson Bulletin 72:156-181.

BeERs, T. W., P. E. Dress, AND L. C. WenSEL. 1966. Aspect transformation in site productivity research. Journal of Forestry 64:691-692.

BERTIN, R. I. 1975. Factors influencing the distribution of the wood thrush and veery in western Connecticut woodland. M.S. thesis, University of Connecticut, Storrs.

BERTIN, R. I. 1977. Breeding habitats of the wood thrush and veery. Condor 79:303-311.

Breiman, L., J. H. Friedman, R. A. Olshen, And C. J. Stone. 1984. Classification and regression trees. Wadsworth, Belmont, California.

BURKE, D. M., AND E. NOL. 2000. Landscape and fragment size effects on reproductive success of forest-breeding birds in Ontario. Ecological Applications 10:1749-1761. 
Clark, L. A., And D. Pregibon. 1992. Tree-based models. Pages 377-419 in Statistical models in S (J. M. Chambers and T. J. Hastie, Eds.) Wadsworth \& Brooks, Pacific Grove, California.

Clark, R. G., AND D. ShUTLER. 1999. Avian habitat selection: pattern from process in nest-site use by ducks? Ecology 80:272-287.

Crawford, H. S., R. G. HoOper, And R. W. TitTerington. 1981. Songbird population response to silvicultural practices in central Appalachian hardwoods. Journal of Wildlife Management 45:680-692.

Dececco, J. A., M. R. Marshall, A. B. Williams, G. A. Gale, And R. J.Cooper. 2000. Comparative seasonal fecundidty of four Neotropical migrants in Middle Appalachia. Condor 102:653-663.

Dellinger, R. L., P. B. WoOd, AND P. KEYSER. 2004. Songbird abundance and nesting success on landscapes of differing harvesting intensities on an industrial forest. Final Project Report, US Fish and Wildlife Service, Neotropical Migratory Bird Conservation Act Grant Program, Arlington, Virginia.

DeMeritTe, E. 1920. Peculiar nestings of hermit thrushes. Auk 37:138-140.

DilgER, W.C. 1956a. Adaptive modification and ecological isolating mechanisms in the thrush genera Catharus and Hylocichla. Wilson Bulletin 68:171-199.

DILGER, W.C. 1956b. Hostile behavior and reproductive isolating mechanisms in the avian genera Catharus and Hylocichla. Auk 73:313-353.

Dowdy, S., AND S. WEARDEN. 1983. Statistics for research. Wiley, New York.

Duguay, J. P., P. B. Wood, AND J. V. Nichols. 2001. Songbird abundance and avian nest survival rates in forests fragmented by different silvicultural treatments. Conservation Biology 15:1405-1415.

EHRLiCH, P. R., D. S. DobKIN, AND D. WheYE. 1988. The birder's handbook. Simon and Schuster, Inc., New York.

Flaspohler, D. J., AND S. A. TEMPLE. 2000. Relationship between nest success and concealment in two ground-nesting passerines. Journal of Field Ornithology 71:736-747.

Fox, T. J., M.G. KNUTSON, AND R. K. HinES. 2000. Mapping forest canopy gaps using air-photo interpretation and ground surveys. Wildlife Society Bulletin 28:882-889.

Gross, A. O. 1949. Eastern Hermit Thrush. Pages 143-162 in Life histories of North American thrushes, kinglets, and their allies (A. C. Bent, Ed.). United States National Museum Bulletin 196, Washington D.C. 
Hagan, J. M., W. M. Vander Haegen, And P. S. MCKinley. 1996. The Early development of forest fragmentation effects on birds. Conservation Biology 10:188-202.

Hall, G. A. 1983. West Virginia birds. Carnegie Museum of Natural History, Pittsburgh.

HALl, G. A. 1984. A long-term bird population study in an Appalachian spruce forest. Wilson Bulletin 96:228-240.

HAZLER, K. R. 2004. Mayfield logistic regression: a practical approach for analysis of nest survival. Auk 121:707-716.

HECKSCHER, C. M. 2004. Veery nest sites in a mid-Atlantic piedmont forest: vegetative physiognomy and use of alien shrubs. American Midland Naturalist 151:326-337.

HICKS, R. R. JR. 1998. Ecology and management of central hardwood forests. John Wiley, New York.

Hines, J.E, AND J. R. SAUER. 1989. Program CONTRAST-A General Program for the Analysis of Several Survival or Recovery Rate Estimates. US Fish \& Wildlife Service, Fish \& Wildlife Technical Report 24, Washington, DC. http://www.mbrpwrc.usgs.gov/software.html\#contrast.

Holmes, R. T, R. E. Bonney, And S. W. PaCAlA. 1979. Guild structure of the Hubbard Brook bird community: a multivariate approach. Ecology 60:512-520.

Hosmer, D. W., AND S. LemeSHOW. 1989. Applied logistic regression: John Wiley and Sons, New York.

HowelL, J. C. 1942. Notes on the nesting habits of the American Robin (Turdus migratorius L.). American Midland Naturalist 28:529-603.

JAMES, F. C. 1971. Ordinations of habitat relationships among breeding birds. Wilson Bulletin 83:215-236.

JAmES, F. C, AND H. H. Shugart. 1970. A quantitative method of habitat description. Audubon Field Notes 24:727-736.

Johnston, V. R. 1943. An ecological study of nesting birds in the vicinity of Boulder, Colorado. Condor 45:61-68.

Jones, P. W., And T. M. Donovan. 1996. Hermit Thrush (Catharus guttatus). In The Birds of North America, no. 261 (A. Poole and F. Gill, Eds.). Academy of Natural Sciences, Philadelphia, and American Ornithologists' Union, Washington, D.C.

Karels, T. J., A. A. Bryant, AND D. S. Hik. 2004. Comparison of discriminant function and classification tree analyses for age classification of marmots. Oikos 105:575-587. 
KNight, R. L. 1997. Hermit thrush. Pp 379-381 in. Atlas of the breeding birds of Tennessee (C. P. Nicholson, Ed.). University of Tennessee Press, Knoxville.

Manolis, J. C, D. E. Anderson, And F. J. Cuthbert. 2000. Uncertain nest fates in songbird studies and variation in Mayfield estimation. Auk 117:615-626.

Martin, N. D. 1960. An analysis of bird populations in relation to forest succession in Algonquin Provincial Park, Ontario. Ecology 41:126-240.

MARTIN, T. E. 1988. On the advantage of being different: nest predation and the coexistence of bird species. Proceedings of the National Academy of Sciences of the United States of America 85:2196-2199.

MARTIN, T. E. 1996. Fitness costs of resource overlap among coexisting bird species. Nature 380:338-340.

MARTIN, T. E., AND G. R. GUEPEL. 1993. Nest-monitoring plots: methods for locating and monitoring success. Journal of Field Ornithology 64:507-519.

Martin, T. E., C. Paine, C. H. Conway, W. M. Hochachka, P. Allen, and W. JENKINS. 1997. BBIRD Field Protocol. USGS, Biological Resources Division, Montana Cooperative Fish and Wildlife Research Unit, Missoula, Montana. http://pica.wru.umt.edu/bbird/

Martin, T. E., C. Paine, C. H. Conway, W. M. HochachKa, P. Allen, And W. JENKINS. 2004. BBIRD database. USGS, Biological Resources Division, Montana Cooperative Fish and Wildlife Research Unit, Missoula, Montana. http://pica.wru.umt.edu/bbird/

MARTIN, T. E., AND J. J. ROPER. 1988. Nest predation and nest site selection in a western population of the Hermit Thrush. Condor 90:51-57.

MAYFIELD, H. F. 1961. Nesting success calculated from exposure. Wilson Bulletin 73:255-261.

MAYFIELD, H. F. 1975. Suggestions for calculating nest success. Wilson Bulletin 87:456-466.

MCNAIR, D. B. 1987. Recent breeding information on birds in a portion of the Southern Appalachian Mountains. Migrant 58:109-34.

MORSE, D. H. 1971. Effects of the arrival of a new species upon habitat utilization by two forest thrushes in Maine. Wilson Bulletin 83:57-65.

Morse, D. H. 1972. Habitat differences of Swainson's and Hermit thrushes. Wilson Bulletin 84:206-208. 
Moskoff, W. 1995. Veery (Catharus fuscescens). In The Birds of North America, no. 142 (A. Poole and F. Gill, Eds.). Academy of Natural Sciences, Philadelphia, and American Ornithologists' Union, Washington, D.C.

Murphy. M. T., C. L. Cummings, And M. S. PALMER. 1997. Comparative analysis of habitat selection, nest site and nest success by cedar waxwings (Bombycilla cedrorum) and eastern kingbirds (Tyrannus tyrannus). American Midland Naturalist 138:344-356.

NoON, B. R. 1981. The distribution of an avian guild along a temperate elevational gradient: the importance and expression of competition. Ecological Monographs 51:105-124.

NuR, N., S. L. JONES, AND G. R. GEUPEL. 1999. A statistical guide to data analysis of avian monitoring programs. U. S. Fish and Wildlife Service Biological Techniques Publication BTP-R6001-1999.

O'CONNOR, R. J. AND T. L. WAGNER. 2004. A test of a regression-tree model of species distribution. Auk 121:604-609.

PASZKOWSKI, C. A. 1984. Macrohabitat use, microhabitat use, and foraging behavior of the Hermit Thrush and Veery in a northern Wisconsin forest. Wilson Bulletin 96:286-292.

Pietrewicz, A. T., AND A. C. KamiL. 1979. Search image formation in the blue jay Cyanocitta cristata. Science 204:1332-1333.

R Development Core TeAm. 2004. R: A language and environment for statistical computing. R Foundation for Statistical Computing, Vienna, Austria. http://www.R-project.org

Rejwan, C., N. C. Collins, L. J. Brunner, B. J. Shuter, And M. S. Ridgway. 1999. Tree regression analysis of the nesting habitat of smallmouth bass. Ecology 80:341-348.

RoSENZWEIG, M. L. 1981. A theory of habitat selection. Ecology 62:327-335.

RosEnZWEIG, M. L. 1987. Habitat selection as a source of biological diversity. Evolutionary Ecology 1:315-330.

Roth, R. R, M. S. JoHnSON, AND T. J. UndERWOOD. 1996. Wood Thrush (Hylocichla mustelina). In The Birds of North America, no. 246 (A. Poole and F. Gill, Eds.). Academy of Natural Sciences, Philadelphia, and American Ornithologists' Union, Washington, D.C.

SAS InSTITUTE. 2004. Cary, North Carolina.

SEALY, S. G. 1974. Ecological segregation of Swainson's and Hermit Thrushes on Langara Island, British Columbia. Condor 76:350-351.

TINBERGEN, L. 1960. The natural control of insects in pinewoods. 1. Factors influencing the intensity of predation by songbirds. Archives Néerlandaises de Zoologie 13:265-343. 
Titus, K., J. A. Mosher, AND B. K. Williams. 1984. Chance-corrected classification for use in discriminant analysis: ecological applications. American Midland Naturalist 111:1-7.

ToDD, W. C. 1940. Birds of western Pennsylvania. University of Pittsburgh Press, Pittsburgh.

WeAver, F. G. 1949. Wood Thrush. Pages 101-123 in Life histories of North American thrushes, kinglets, and their allies (A. C. Bent, Ed.). United States National Museum Bulletin 196, Washington D.C.

Whitcomb, R. F., C. S. Robbins, J. F. Lynch, B. L. Whitcomb, M .K. KLimKiewicz, And D. BYSTRAK. 1981. Effects of forest fragmentation on avifauna of the eastern deciduous forest. Pages 125-206 in Forest island dynamics in man-dominated landscapes (R. L. Burgess RL, and B. M. Sharpe, Eds.). Springer-Verlag, New York.

Whitmore, R. C. 1977. Habitat partitioning in a community of passerine birds. Wilson Bulletin $89: 253-265$.

WitMer, M. C. 1998. Do seeds hinder digestive processing of fruit pulp? Implications for plant/frugivore mutualisms. Auk 115:319-326. 
Table 1. Descriptions of habitat variables sampled at 141 thrush nests during 2001-2003 in Randolph County, West Virginia.

\begin{tabular}{|c|c|}
\hline Variable & Description \\
\hline \multicolumn{2}{|l|}{ Nest substrate variables } \\
\hline Nest height (m) & Height of nest from the ground \\
\hline Substrate height ${ }^{\mathrm{a}}(\mathrm{m})$ & Height of substrate in which nest was located \\
\hline Diameter of substrate $^{\mathrm{a}}(\mathrm{cm})$ & Diameter of nesting substrate; recorded as diameter at breast height (dbh) \\
\hline Number of branches ${ }^{\mathrm{a}}$ & Number of branches directly supporting the nest \\
\hline Supporting branches ${ }^{\mathrm{a}}(\mathrm{cm})$ & Average diameter of all supporting branches \\
\hline Canopy cover $(\%)$ & Estimated percent canopy cover directly above nest \\
\hline \multicolumn{2}{|l|}{ Nest site variables } \\
\hline Canopy height (m) & Average height of dominant and codominant trees within plot \\
\hline Distance to edge $(\mathrm{m})$ & Distance to nearest edge \\
\hline Slope $(\%)$ & Slope of $5 \mathrm{~m}$ plot centered on nest, measured with a clinometer \\
\hline Aspect & Azimuth directly downhill from nest \\
\hline Ground Cover $(\%)$ & Measured with site tube at 20 points on $11.3 \mathrm{~m}$ transects \\
\hline Herbaceous & Percent of ground within plot covered by vegetation $<0.5 \mathrm{~m}$ in height \\
\hline Litter & Percent of ground within plot covered by leaf litter \\
\hline Woody debris & Percent of ground within plot covered by woody debris \\
\hline Bare & Percent of bare ground within plot \\
\hline Moss & Percent of ground within plot covered by moss \\
\hline Water & Percent of ground within plot covered by permanent or ephemeral streams \\
\hline \multicolumn{2}{|l|}{ Canopy Cover $(\%)$} \\
\hline $3.0 \mathrm{~m}$ & Percent of plot covered by a tree canopy up to $3.0 \mathrm{~m}$ tall \\
\hline $3.1-6.0 \mathrm{~m}$ & Percent of plot covered by a tree canopy 3.1-6.0 m tall \\
\hline $6.1-12.0 \mathrm{~m}$ & Percent of plot covered by a tree canopy $6.1-12.0 \mathrm{~m}$ tall \\
\hline $12.1-18.0 \mathrm{~m}$ & Percent of plot covered by a tree canopy $12.1-18.0 \mathrm{~m}$ tall \\
\hline $18.1-24.0 \mathrm{~m}$ & Percent of plot covered by a tree canopy $18.1-24.0 \mathrm{~m}$ tall \\
\hline$>24.0 \mathrm{~m}$ & Percent of plot covered by a tree canopy greater than $24.0 \mathrm{~m}$ tall \\
\hline \multicolumn{2}{|l|}{$\underline{\text { Stem Densities (no./plot) }}$} \\
\hline Sapling & $\begin{array}{l}\text { Number of woody stems (shrub or tree) less than } 7.6 \mathrm{~cm} \text { dbh } \\
\text { within a } 5 \mathrm{~m} \text { radius of nest }\end{array}$ \\
\hline Small tree & Number of trees $7.6-22.9 \mathrm{~cm}$ trees dbh within an $11.3 \mathrm{~m}$ radius of nest \\
\hline Medium tree & Number of trees $23.0-38.0 \mathrm{~cm}$ dbh within an $11.3 \mathrm{~m}$ radius of nest \\
\hline Large tree & Number of trees $>38.0 \mathrm{~cm}$ dbh within an $11.3 \mathrm{~m}$ radius of nest \\
\hline Snag & Number of standing dead trees $>7.6 \mathrm{~cm}$ dbh within an $11.3 \mathrm{~m}$ radius of nest \\
\hline
\end{tabular}

\section{$\underline{\text { Territory variables }}$}

Slope position

Aspect

Elevation (m)

Presence/absence of $^{\text {b: }}$

Skid trail

Even-aged timber harvest

Lower, middle or upper portion of slope, measured on topographic map

Direction slope is facing, measured on topographic map

Elevation

Linear, vegetated canopy opening created by past logging activities

Area in which most trees were removed in a single operation 
Table 1, cont'd.

\begin{tabular}{|c|c|}
\hline Variable & Description \\
\hline \multicolumn{2}{|c|}{ Presence/absence of ${ }^{\mathrm{b}}$ : } \\
\hline Water & Standing or running water \\
\hline Grass & Gas well clearings, log landings, roadsides or wildlife plantings \\
\hline Road & Paved, gravel, or dirt road \\
\hline Development & Man-made structure \\
\hline
\end{tabular}

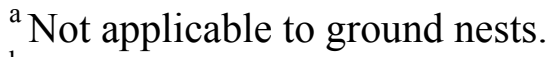

${ }^{\mathrm{b}}$ Available for 119 of 141 nests monitored 
Table 2. Results of MANOVA to determine overall differences in habitat variables sampled at 141 nest sites of four thrush species during 2001-2003 in Randolph County, West Virginia.

AMRO $=$ American Robin, HETH $=$ Hermit Thrush, VEER $=$ Veery, WOTH $=$ Wood Thrush.

\begin{tabular}{|c|c|c|c|c|c|c|}
\hline & \multicolumn{3}{|c|}{ Nest Substrate $^{\mathrm{a}}$} & \multicolumn{3}{|c|}{ Nest Site } \\
\hline & Wilk's $\lambda$ & $\mathrm{F}$ & $P$ & Wilk's $\lambda$ & $\mathrm{F}$ & $P$ \\
\hline Overall & 0.26 & 16.87 & $<0.01$ & 0.22 & 3.64 & $<0.01$ \\
\hline \multicolumn{7}{|l|}{ Pair-wise } \\
\hline AMRO-HETH & $\mathrm{a}$ & a & a & 0.67 & 2.80 & $<0.01$ \\
\hline AMRO-VEER & 0.55 & 14.01 & $<0.01$ & 0.70 & 2.38 & $<0.01$ \\
\hline AMRO-WOTH & 0.73 & 6.49 & $<0.01$ & 0.69 & 2.46 & $<0.01$ \\
\hline HETH-VEER & a & a & a & 0.53 & 4.98 & $<0.01$ \\
\hline HETH-WOTH & a & a & a & 0.39 & 8.59 & $<0.01$ \\
\hline VEER-WOTH & 0.35 & 31.86 & $<0.01$ & 0.67 & 2.77 & $<0.01$ \\
\hline
\end{tabular}

${ }^{a}$ Nesting substrate scale analyses excluded Hermit Thrush nests due to high incidence of ground nesting in this species, which limited number of applicable variables. 
Table 3. Means and standard errors (SE) of variables sampled at 141 thrush nests during 2001-2003 in Randolph County, West Virginia. The number of nests sampled is indicated by $n$. Within a row, means with different letters differed at $P<0.05$.

\begin{tabular}{|c|c|c|c|c|c|c|c|c|c|c|c|c|c|c|}
\hline \multirow[b]{2}{*}{$\underline{\text { Variable }}$} & \multicolumn{3}{|c|}{ American Robin } & \multicolumn{3}{|c|}{ Hermit Thrush } & \multicolumn{3}{|c|}{ Veery } & \multicolumn{3}{|c|}{ Wood Thrush } & \multirow[b]{2}{*}{$\mathrm{F}$} & \multirow[b]{2}{*}{$P$} \\
\hline & $\mathrm{n}$ & Mean & $\mathrm{SE}$ & $\mathrm{n}$ & Mean & SE & $\mathrm{n}$ & Mean & SE & $\mathrm{n}$ & Mean & SE & & \\
\hline \multicolumn{15}{|l|}{ Nesting substrate } \\
\hline Nest height & 17 & $3.3 \mathrm{~A}$ & 1.1 & $5^{\mathrm{b}}$ & $0.7 \mathrm{~B}$ & 0.3 & 46 & $0.7 \mathrm{~B}$ & 0.06 & 50 & $3.0 \mathrm{~A}$ & 0.1 & 15.55 & $<0.01$ \\
\hline Substrate height & 17 & $6.0 \mathrm{~A}$ & 1.3 & $5^{\mathrm{b}}$ & $2.1 \mathrm{~B}$ & 0.4 & 46 & $1.9 \mathrm{~B}$ & 0.34 & 50 & $5.2 \mathrm{~A}$ & 0.5 & 10.47 & $<0.01$ \\
\hline Dbh of substrate & 17 & $8.2 \mathrm{~A}$ & 2.0 & $5^{\mathrm{b}}$ & $2.7 \mathrm{BC}$ & 1.0 & 46 & $1.2 \mathrm{C}$ & 0.21 & 50 & $4.8 \mathrm{~B}$ & 0.5 & 14.23 & $<0.01$ \\
\hline Num. supp. branches & $16^{\mathrm{a}}$ & $2.9 \mathrm{~B}$ & 0.4 & $5^{\mathrm{b}}$ & $2.8 \mathrm{~B}$ & 0.5 & 46 & $6.4 \mathrm{~A}$ & 0.46 & 50 & $3.8 \mathrm{~B}$ & 0.2 & 17.12 & $<0.01$ \\
\hline Diam. of supp. branch & $16^{\mathrm{a}}$ & $1.4 \mathrm{~A}$ & 0.2 & $5^{\mathrm{b}}$ & $0.9 \mathrm{AB}$ & 0.4 & 46 & $0.7 \mathrm{~B}$ & 0.10 & 50 & $1.4 \mathrm{AB}$ & 0.1 & 5.00 & $<0.01$ \\
\hline Canopy Cover & $16^{\mathrm{a}}$ & $54.7 \mathrm{~B}$ & 11.3 & $5^{\mathrm{b}}$ & $9.0 \mathrm{C}$ & 7.8 & 46 & $66.6 \mathrm{AB}$ & 5.70 & 50 & $86.3 \mathrm{~A}$ & 2.6 & 10.84 & $<0.01$ \\
\hline \multicolumn{15}{|l|}{ Nest site characteristics } \\
\hline Canopy Height & 17 & 21.0 & 1.2 & 28 & 19.1 & 0.5 & 46 & 20.1 & 0.60 & 50 & 21.4 & 0.6 & 2.25 & 0.09 \\
\hline Aspect & 17 & 1.1 & 0.2 & 28 & 1.0 & 0.1 & 46 & 1.1 & 0.09 & 50 & 1.0 & 0.1 & 0.17 & 0.92 \\
\hline Distance to edge & 17 & $9.5 \mathrm{~B}$ & 3.2 & 28 & $6.4 \mathrm{~B}$ & 1.8 & 46 & $16.5 \mathrm{AB}$ & 2.99 & 50 & $23.4 \mathrm{~A}$ & 3.7 & 4.93 & $<0.01$ \\
\hline Slope & 17 & $27.6 \mathrm{~A}$ & 4.1 & 28 & $17.8 \mathrm{~B}$ & 1.8 & 46 & $27.9 \mathrm{~A}$ & 2.58 & 50 & $29.3 \mathrm{~A}$ & 1.8 & 4.16 & 0.01 \\
\hline \multicolumn{15}{|l|}{ Groundcover } \\
\hline Herbaceous & 17 & 30.3 & 4.7 & 28 & 30.2 & 4.8 & 46 & 27.1 & 3.19 & 50 & 20.1 & 2.3 & 1.86 & 0.14 \\
\hline Litter & 17 & $35.6 \mathrm{~B}$ & 4.7 & 28 & $38.8 \mathrm{~B}$ & 4.3 & 46 & $51.9 \mathrm{~A}$ & 3.51 & 50 & $58.7 \mathrm{~A}$ & 2.7 & 7.88 & $<0.01$ \\
\hline Woody debris & 17 & $12.1 \mathrm{~A}$ & 2.5 & 28 & $3.8 \mathrm{~B}$ & 0.9 & 46 & $12.9 \mathrm{~A}$ & 1.82 & 50 & $12.2 \mathrm{~A}$ & 0.9 & 10.76 & $<0.01$ \\
\hline Bare & 17 & 10.6 & 2.9 & 28 & 7.9 & 1.6 & 46 & 5.8 & 1.31 & 50 & 6.8 & 1.2 & 1.27 & 0.29 \\
\hline Moss & 17 & $10.6 \mathrm{~B}$ & 3.6 & 28 & $19.5 \mathrm{~A}$ & 4.0 & 46 & $2.2 \mathrm{C}$ & 0.59 & 50 & $2.1 \mathrm{C}$ & 0.4 & 17.21 & $<0.01$ \\
\hline Water & 17 & 0.9 & 0.6 & 28 & 0.0 & 0.0 & 46 & 0.2 & 0.15 & 50 & 0.1 & 0.1 & 2.00 & 0.12 \\
\hline \multicolumn{15}{|l|}{ Canopy Cover } \\
\hline $3.0 \mathrm{~m}$ & 17 & $55.9 \mathrm{~B}$ & 5.1 & 28 & $40.5 \mathrm{C}$ & 4.4 & 46 & $58.4 \mathrm{~B}$ & 3.58 & 50 & $73.1 \mathrm{~A}$ & 2.5 & 12.67 & $<0.01$ \\
\hline $3.1-6.0 \mathrm{~m}$ & 17 & $45.9 \mathrm{~B}$ & 5.7 & 28 & $46.4 \mathrm{~B}$ & 4.6 & 46 & $51.2 \mathrm{~B}$ & 4.07 & 50 & $65.3 \mathrm{~A}$ & 3.6 & 5.11 & $<0.01$ \\
\hline $6.1-12.0 \mathrm{~m}$ & 17 & 37.4 & 6.6 & 28 & 50.1 & 5.3 & 46 & 53.0 & 4.79 & 50 & 58.1 & 4.0 & 1.91 & 0.13 \\
\hline $12.1-18.0 \mathrm{~m}$ & 17 & $40.6 \mathrm{~B}$ & 7.8 & 28 & $39.1 \mathrm{~B}$ & 5.4 & 46 & $54.7 \mathrm{AB}$ & 4.45 & 50 & $64.2 \mathrm{~A}$ & 4.3 & 4.47 & 0.01 \\
\hline $18.1-24.0 \mathrm{~m}$ & 17 & $32.4 \mathrm{BC}$ & 8.3 & 28 & $19.0 \mathrm{C}$ & 5.3 & 46 & $35.1 \mathrm{~B}$ & 4.90 & 50 & $56.6 \mathrm{~A}$ & 5.1 & 8.98 & $<0.01$ \\
\hline$>24.0 \mathrm{~m}$ & 17 & 5.0 & 3.0 & 28 & 5.5 & 3.6 & 46 & 10.4 & 3.34 & 50 & 6.2 & 2.2 & 2.37 & 0.07 \\
\hline
\end{tabular}


Table 3, cont'd.

\begin{tabular}{|c|c|c|c|c|c|c|c|c|c|c|c|c|c|c|}
\hline \multirow[b]{2}{*}{ Variable } & \multicolumn{3}{|c|}{ American Robin } & \multicolumn{3}{|c|}{ Hermit Thrush } & \multicolumn{3}{|c|}{ Veery } & \multicolumn{3}{|c|}{ Wood Thrush } & \multirow[b]{2}{*}{$\mathrm{F}$} & \multirow[b]{2}{*}{$P$} \\
\hline & $\mathrm{n}$ & Mean & SE & $\mathrm{n}$ & Mean & SE & $\mathrm{n}$ & Mean & SE & $\mathrm{n}$ & Mean & SE & & \\
\hline \multicolumn{15}{|l|}{ Stem Densities } \\
\hline Saplings & 17 & $128.4 \mathrm{~B}$ & 28.2 & 28 & $103.4 \mathrm{~B}$ & 22.9 & 46 & $197.7 \mathrm{~A}$ & 19.0 & 50 & $124.7 \mathrm{~B}$ & 15.7 & 5.80 & $<0.01$ \\
\hline Trees 7.6-22.9 cm dbh & 17 & $5.9 \mathrm{~B}$ & 1.7 & 28 & $10.3 \mathrm{~A}$ & 1.3 & 46 & $9.9 \mathrm{~A}$ & 1.0 & 50 & $8.7 \mathrm{~A}$ & 0.7 & 13.06 & 0.03 \\
\hline Trees $22.9-38.1 \mathrm{~cm} \mathrm{dbh}$ & 17 & $2.4 \mathrm{~B}$ & 0.7 & 28 & $3.2 \mathrm{~A}$ & 0.3 & 46 & $3.9 \mathrm{~A}$ & 0.4 & 50 & $4.0 \mathrm{~A}$ & 0.5 & 3.03 & 0.03 \\
\hline Trees $>38.1 \mathrm{~cm} \mathrm{dbh}$ & 17 & $1.2 \mathrm{~B}$ & 0.6 & 28 & $1.7 \mathrm{AB}$ & 0.4 & 46 & $2.0 \mathrm{~A}$ & 0.2 & 50 & $2.4 \mathrm{~A}$ & 0.3 & 3.77 & 0.01 \\
\hline Snags & 17 & 1.2 & 0.4 & 28 & 2.5 & 0.5 & 46 & 1.3 & 0.3 & 50 & 1.4 & 0.3 & 2.31 & 0.07 \\
\hline \multicolumn{15}{|l|}{ Territory scale variables } \\
\hline Elevation & 17 & $952.8 \mathrm{~B}$ & 21.8 & 28 & $1011.9 \mathrm{~A}$ & 10.9 & 46 & $921.6 \mathrm{~B}$ & 15.0 & 50 & $784.7 \mathrm{C}$ & 13.0 & 44.88 & $<0.01$ \\
\hline Aspect & 17 & $1.5 \mathrm{AB}$ & 0.2 & 28 & $1.6 \mathrm{~A}$ & 0.1 & 46 & $1.1 \mathrm{~B}$ & 0.1 & 50 & $1.6 \mathrm{~A}$ & 0.1 & 3.72 & 0.01 \\
\hline
\end{tabular}

${ }^{a}$ These variables were not measurable on one extremely high nest

${ }^{\mathrm{b}}$ Means of Hermit Thrush nests located in trees. Shown here for comparison purposes, but not included in multivariate analyses due to small incidence of tree-nesting in this species, a behavior which may not be representative of the majority of individuals of the species. 
Table 4. Percent of nests ( $n=141)$ of each of four thrush species sampled during 2001-2003 in Randolph County, West Virginia that were correctly and incorrectly classified using a classification tree analysis at each of three spatial scales. $\mathrm{K}$ is equal to the ratio of how much the model improves classification over what would be expected under random assignment.

\begin{tabular}{|c|c|c|c|c|c|c|}
\hline Scale & $\begin{array}{l}\text { No. } \\
\text { Nests }\end{array}$ & $\begin{array}{c}\text { American } \\
\text { Robin }\end{array}$ & $\begin{array}{l}\text { Hermit } \\
\text { Thrush }\end{array}$ & Veery & $\begin{array}{l}\text { Wood } \\
\text { Thrush }\end{array}$ & $\mathrm{K}$ \\
\hline \multicolumn{7}{|l|}{ Nest Substrate } \\
\hline American Robin & 17 & 0 & 0 & 29 & 71 & 0.73 \\
\hline Hermit Thrush & 0 & 0 & 0 & 0 & 0 & \\
\hline Veery & 46 & 0 & 0 & 98 & 2 & \\
\hline Wood Thrush & 50 & 0 & 0 & 4 & 96 & \\
\hline \multicolumn{7}{|l|}{ Nest Site } \\
\hline American Robin & 17 & 47 & 0 & 35 & 18 & 0.58 \\
\hline Hermit Thrush & 28 & 11 & 46 & 36 & 7 & \\
\hline Veery & 46 & 0 & 4 & 78 & 17 & \\
\hline Wood Thrush & 50 & 2 & 4 & 14 & 80 & \\
\hline \multicolumn{7}{|l|}{ Territory } \\
\hline American Robin & 17 & 35 & 24 & 24 & 17 & 0.60 \\
\hline Hermit Thrush & 28 & 4 & 93 & 4 & 0 & \\
\hline Veery & 46 & 4 & 13 & 61 & 22 & \\
\hline Wood Thrush & 50 & 2 & 6 & 14 & 78 & \\
\hline
\end{tabular}


Table 5. Reduction in diversity measures provided by splitting at variables in recursive classification models for habitat variables sampled at thrush nests $(n=141)$ during 2001-2003 in Randolph County, West Virginia.

\begin{tabular}{lrr}
\hline $\begin{array}{l}\text { Splitting } \\
\text { variable }\end{array}$ & $\begin{array}{c}\text { Diversity } \\
\text { score }\end{array}$ & $\begin{array}{r}\text { Diversity } \\
\text { reduction }\end{array}$ \\
\hline Substrate & 228.7 & 0.0 \\
\multicolumn{1}{c}{ None } & 121.7 & 107.0 \\
$\quad$ Nest height & 369.2 & 0.0 \\
Nest Site & 326.8 & 42.4 \\
$\quad$ None & 322.2 & 4.6 \\
Distance to edge & 318.2 & 4.0 \\
Medium trees & 312.7 & 5.5 \\
Woody debris & 311.2 & 1.5 \\
Saplings & & \\
0-3m canopy & 369.1 & 0.0 \\
Territory & 300.2 & 68.9 \\
None & 287.6 & 12.7 \\
Elevation $(847 \mathrm{~m})$ & 280.9 & 6.7 \\
Elevation $(1030 \mathrm{~m})$ & 263.0 & 17.8 \\
Aspect & 262.7 & 0.3 \\
Slope position & 261.5 & 1.2 \\
Presence of water & & \\
Elevation (896m) &
\end{tabular}


Table 6. Percent of nests ( $n=119)$ of four thrush species monitored during 2001-2003 in Randolph County, West Virginia with habitat features present within a 4.0 ha plot centered on the nest.

\begin{tabular}{lrrrrrr}
\hline & \multicolumn{7}{c}{ Percent of Nests with Habitat Features Present } \\
\cline { 2 - 7 } Species & Skid trail & Road & Clearcut & Water & Grass & Develop. \\
\hline American Robin & 100 & 81 & 44 & 94 & 69 & 0 \\
Hermit Thrush & 93 & 85 & 37 & 85 & 70 & 0 \\
Veery & 97 & 82 & 36 & 77 & 59 & 0 \\
Wood Thrush & 98 & 80 & 33 & 70 & 63 & 4 \\
\hline
\end{tabular}

Table 7. Percent of nests ( $n=141$ ) of four thrush species monitored during 2001-2003 in Randolph County, West Virginia located on lower, middle, and upper slopes, and results of Fisher's Exact tests for differences in slope position. $P$ indicates the probability of a similar frequency table being generated by chance.

\begin{tabular}{lrrrrrrrrr}
\hline & \multicolumn{3}{c}{ Slope Position (\%) } & & \multicolumn{3}{c}{$P$ for pairwise contrasts } \\
\cline { 2 - 4 } \cline { 7 - 9 } Species & Low & Middle & Upper & & American Robin & Hermit Thrush & Veery & Wood Thrush \\
\hline American Robin & 18 & 77 & 5 & & - & $<0.01$ & 0.01 & $<0.01$ \\
Hermit Thrush & 32 & 4 & 64 & & $<0.01$ & - & 0.03 & 0.01 \\
Veery & 30 & 26 & 44 & & $<0.01$ & 0.03 & - & 0.69 \\
Wood Thrush & 36 & 30 & 34 & & $<0.01$ & 0.01 & 0.69 & - \\
\hline
\end{tabular}

Table 8. Survival rates of 128 nests for which survival was calculated, monitored during 20012003 in Randolph County, West Virginia.

\begin{tabular}{lcccccc}
\hline Species & $n$ & Exposure Days & Survival & SE & $\chi^{2}$ & $P$ \\
\hline American Robin & 16 & 214.0 & 0.39 & 0.01 & 4.57 & 0.21 \\
Hermit Thrush & 26 & 299.5 & 0.28 & 0.02 & & \\
Veery & 44 & 410.0 & 0.34 & 0.00 & & \\
Wood Thrush & 47 & 420.0 & 0.21 & 0.00 & & \\
\hline
\end{tabular}




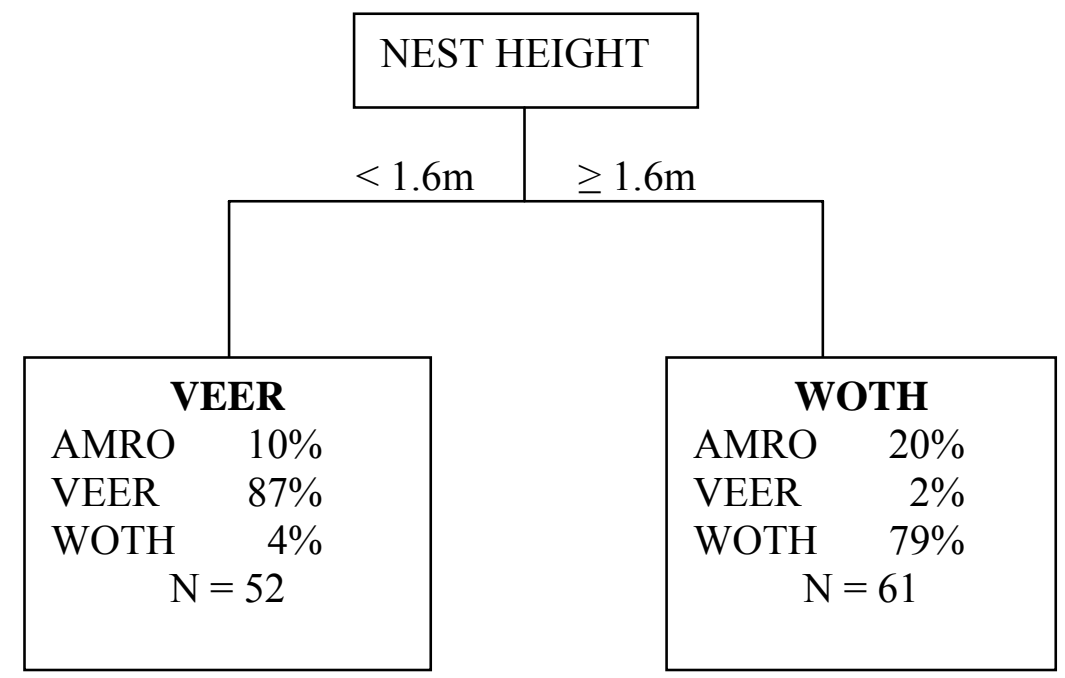

Fig. 1. Classification tree for substrate variables collected at thrush nests $(n=$ 113) during 2001-2003 in Randolph County, West Virginia. Within the box at each terminal node, the species in bold at the top of the box represents all nests monitored of that species $($ AMRO $=$ American Robin, HETH $=$ Hermit Thrush, VEER $=$ Veery, WOTH $=$ Wood Thrush). Values following a species' name indicate the percent of nests belonging to that species that were classified as the species indicated in bold at the top of the box. N represents the total number of nests classified as that species. Hermit Thrush nests were excluded from analysis at this scale due to the small number $(n=5)$ of tree-nesting individuals as compared to ground nesters $(n=23)$. 


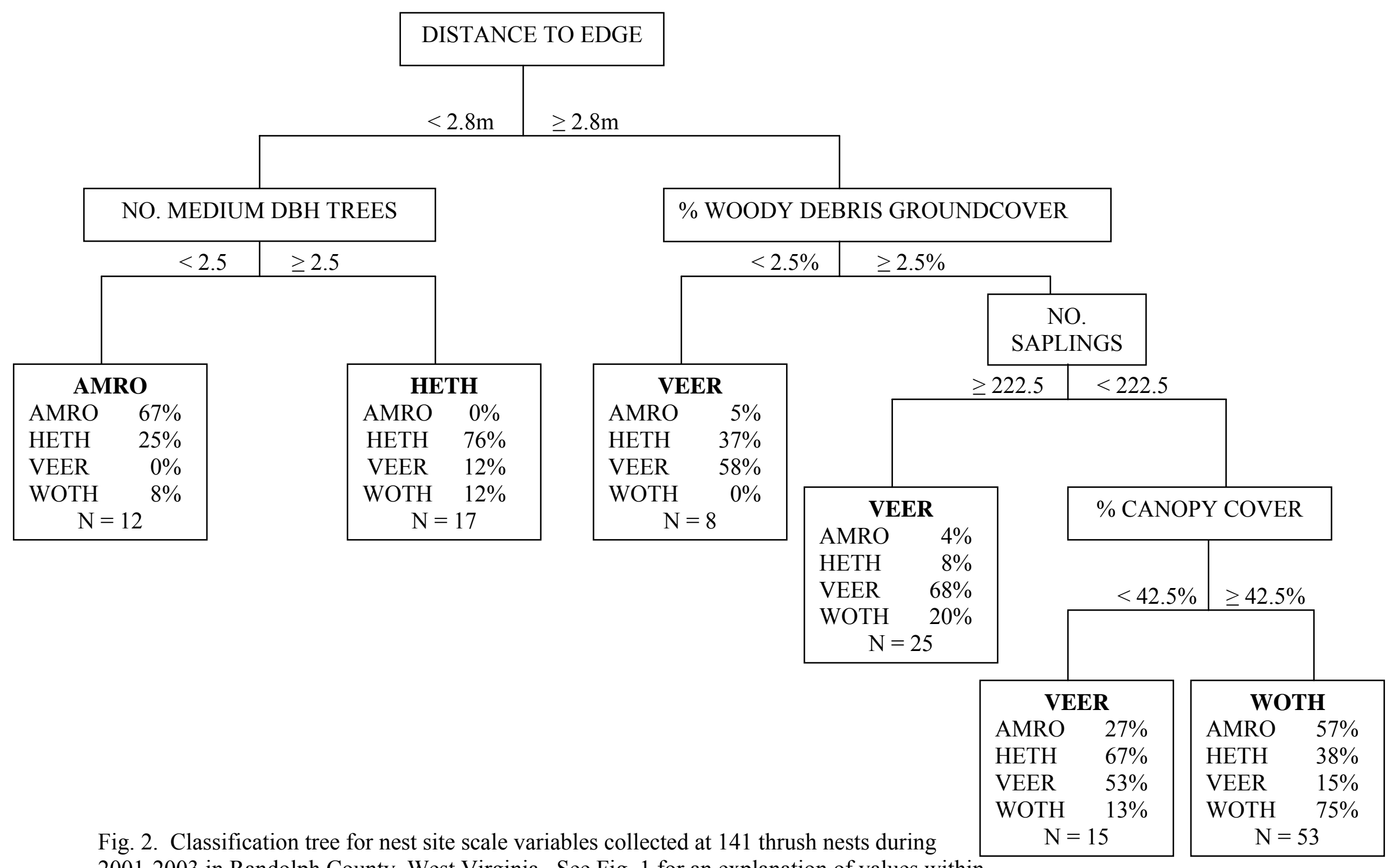

2001-2003 in Randolph County, West Virginia. See Fig. 1 for an explanation of values within boxes. 


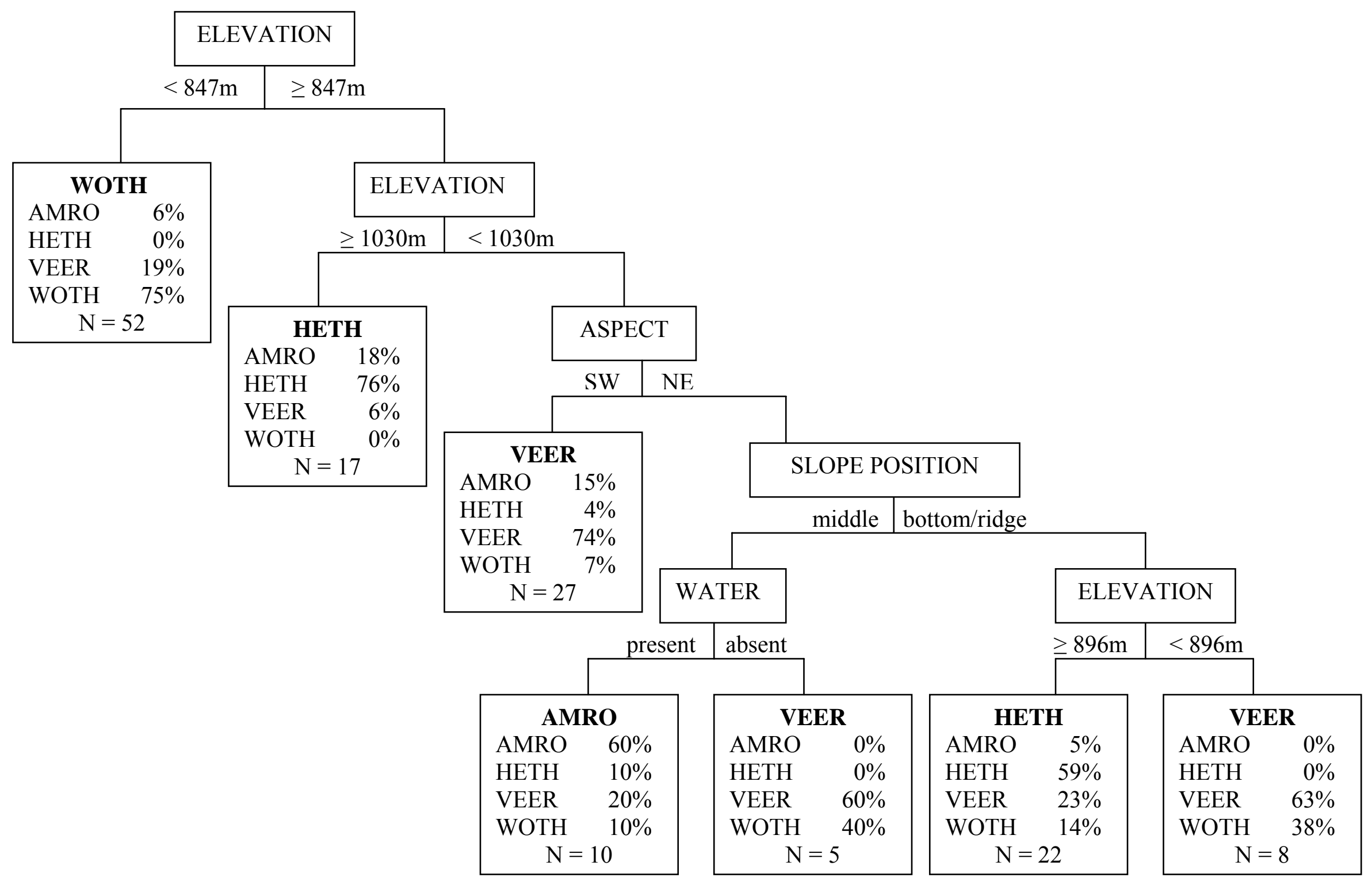

Fig. 3. Classification tree for territory scale variables sampled at 141 thrush nests during 2001-2003 in Randolph County, West Virginia. See Fig. 1 for an explanation of values within boxes. 
CHAPTER 3

OCCURRENCE AND NEST SURVIVAL OF FOUR THRUSH SPECIES ON A MANAGED CENTRAL APPALACHIAN FOREST 


\section{Abstract}

The wood thrush (Hylocichla mustelina Gmelin) is a species of concern in the central Appalachians, and is sympatric there with three closely related species, the American robin (Turdus migratorius Linnaeus), hermit thrush (Catharus guttatus Pallas), and veery (Catharus fuscescens Stephens). Our objectives were to quantify use of mature forests and areas subjected to even-aged harvesting and partial harvesting by these four thrush species by measuring their frequency of occurrence, nest survival, and nest site characteristics. We also investigated the effect of each land cover at the microhabitat scale. During 2001-2003 we conducted point count surveys, monitored nests, and collected nest habitat data on a managed forest in West Virginia. Land cover was digitized into five categories: deciduous and mixed (deciduous-coniferous) mature forest, deciduous and mixed partial harvest, and even-aged regeneration harvest. Chisquare goodness-of-fit analysis and Bonferroni 95\% confidence intervals indicated that deciduous partial harvests were selected by wood thrushes $(P<0.05)$ at the landscape scale; additionally, their occurrence was positively related to increasing area harvested in this manner $\left(B_{o}=0.08, \mathrm{SE}=0.04\right.$, Wald $\chi^{2}=5.25, P=0.02 ; G_{\mathrm{M}}=2.17$, d.f. $\left.=1, P=0.14\right)$ and their nests placed in this land cover had greater survival than those in mature forest $\left(\chi^{2}=45.02 \mathrm{E}+18, P<\right.$ 0.01). The other three species selected against $(P<0.05)$ deciduous partial harvests and had lower nest survival $(P \leq 0.01)$ in partial harvests than in mature forest. Contrary to many published habitat descriptions, three species nested in even-aged harvests, many near a residual canopy tree. All wood thrush $(n=7)$, veery $(n=4)$, and American robin $(n=3)$ nests monitored within even-aged regeneration harvests had higher survival rates $(P<0.01)$ than those nests in other land covers. Hermit thrushes selected against mature deciduous forest $(P<0.05)$, evenaged harvests, and harvested edges but chose nesting areas in mature mixed forest that was 
disturbed by road building and the seeding of log landings and skid trails $>10$ years ago. At the microhabitat scale, landcovers did not differ overall (MANOVA, $P>0.05$ ) but harvests of both types had greater sapling density than did mature forest (ANOVA $P<0.01$ ). When nesting in mature forest, three of four species chose areas of greater sapling density than at a random point within the same stand. Our results suggest a relation with partial harvesting that is positive for wood thrush but negative for the other three species.

Keywords: $\quad$ Even-aged regeneration harvest, Nest survival, Partial harvest, Point count survey, Thrush, Turdidae

\section{Introduction}

The organization, Partners in Flight, has listed the wood thrush (Hylocichla mustelina Gmelin) as a bird of conservation concern, and has identified the effects of logging practices on its nesting ecology, survival, and reproductive success to be a primary research need in the midAtlantic ridge and valley region (Rosenberg, 2003). Furthermore, Breeding Bird Survey data indicate that during 1966-2003 wood thrush populations experienced significant declines throughout the eastern United States (1.84\% per year), and specifically in West Virginia (0.65\% per year) (Sauer et al., 2004). In West Virginia and other parts of this region, the wood thrush belongs to a guild of forest songbirds that also includes the American robin (Turdus migratorius Linnaeus), hermit thrush (Catharus guttatus Pallas), and veery (Catharus fuscescens Stephens). These four thrushes are similar in behavior, anatomy, and breeding phenology, (Moskoff, 1995; Roth et al., 1996) and share considerable overlap in the placement of their nest sites (Gross, 1949) and overall habitat requirements (Dilger, 1956a; b). The veery, while declining throughout the east during 1966-2004, increased by 4.09\% per year in West Virginia (Sauer et 
al., 2004). American robin and hermit thrush populations also increased or remained stable in the state and throughout the east (Sauer et al., 2004). Although one or more thrush species may be able to exploit new seral stages created by harvesting trees, it is possible that the other species' local distributions may be altered or diminished by logging practices if it becomes necessary for them to nest in smaller fragments of mature forest habitat where they may experience interspecific competition for nest sites and other resources (Hagan et al., 1996). Thus, it is necessary to consider management strategies for the guild rather than for the wood thrush alone.

For forest birds in general, clearcutting and other variations of regeneration harvesting can decrease the amount of closed canopy, mature forested habitat available for nesting; decrease the abundance and species richness of invertebrates (Duguay and Wood, 2000; Zettler et al., 2004) and salamanders (Petranka et al., 1993; 1994), which are important food items for many birds; and increase nest predation rates (Robinson et al., 1995; Hartley and Hunter, 1998) and nest parasitism for birds nesting near harvested edges (Paton 1994; Robinson et al., 1995), even when new regeneration harvests are surrounded by intact, forest-dominated landscapes (FenskeCrawford and Niemi, 1997; Flaspohler et al., 2001). Some studies in forested areas, however, have documented that nest survival rates during stand initiation can be similar to or higher than those of nests within mature forests (Hanski et al., 1996; Weakland, 2000; Duguay et al., 2001). Furthermore, as harvested stands grow and develop over time, the availability of soft mast and cover increases (Vega Rivera et al., 1998), creating favorable conditions for birds that nest in shrubby vegetation, as well as for the juveniles of forest interior species, which also use regenerating even-aged harvests during the post-fledging period (Lang et al., 2002; Marshall et al., 2003). 
Partial harvest techniques such as thinning, diameter-limit cutting, and single-tree selection often have little effect on the abundance (Lent and Capen, 1995; Weakland et al., 2002) or nest survival (Robinson and Robinson, 2001) of forest songbirds as long as the overstory canopy closure is not reduced to the point of making the stand unsuitable for forest birds. But the effects of this type of harvesting are species-specific (Bourque and Villard, 2003), and any successional changes to the forest brought about by logging will result in corresponding changes to bird communities (Annand and Thompson, 1997; Robinson and Robinson, 1999); such differences in bird communities can remain apparent up to 28 years after harvesting (Hobson and Schieck, 1999).

Hermit thrushes, which are associated with high elevation spruce and spruce-fir forests in the central and southern Appalachians (Hall, 1984; Knight, 1997), are usually absent from recently clearcut areas (Freedman et al., 1981) and have decreased nesting success near clearcut edges (Manolis et al., 2002), although smaller patches of logging-related disturbance such as skidder trails and log landings may be favored for nesting (Jones and Donovan, 1996). American robins are associated with high elevation spruce-fir forests in the southeastern U.S. (Sallabanks and James, 1999) but also nest in regenerating clearcuts (Martin, 1973) and thinned areas (Sallabanks and James, 1999). They show a great deal of plasticity in their use of nest sites (Dellinger 2005, Chap. 2), and thus may have a competitive advantage in disturbed landscapes, and may benefit from the increased grass density associated with the stabilization of roads by seeding post-harvest (Hamel, 1992). Veeries nest in dense shrubs (Heckscher, 2004), but are less abundant in new regeneration harvests (Weakland, 2000). It also has been suggested that they are an area-sensitive forest interior species (Robbins et al., 1989) and threatened by habitat fragmentation (Moskoff, 1995). Juvenile wood thrushes use regenerating clearcuts and partial 
harvests during the post-natal period (Marshall et al., 2003). Although adult wood thrushes may be unaffected by forest thinning (Powell et al., 2000), removal of the forest canopy could make harvested areas unsuitable for nesting adults, which require the presence of a closed canopy (Crawford et al., 1981; Hall, 1983) and tall trees (Bertin, 1977).

The objective of this study was to quantify the use of a managed forest by the American robin, hermit thrush, veery, and wood thrush by measuring frequency of occurrence, nest survival, and nest site characteristics in mature forests and areas subjected to even-aged regeneration harvesting and partial harvesting. Our objectives were to:

1. determine the effect of land cover categories on species occurrence and nest survival; and to

2. determine if the occurrence and/or nest survival of each species changed as the proportion of each land cover at the study site changed over a 3-year period.

Furthermore, to investigate whether the nest placement strategy of each species was the same in all land cover categories or if nests were placed differently depending upon the land cover, additional objectives were to:

3. describe differences among the land cover categories by quantifying the microhabitat variables present at random locations in each;

4. compare each nest's microhabitat with that of a random point within the surrounding stand;

5. compare the microhabitat characteristics of each species' nests across land cover categories; and to

6. relate microhabitat characteristics to nest survival for each species. 
The response of each thrush species to forest management has been documented elsewhere, but few studies have examined the four species where they are sympatric; such information is important because sustaining populations of the wood thrush where it is sympatric with the other three species may depend on managing for the entire guild.

\section{Methods}

\subsection{Study area}

Our study was conducted at the MeadWestvaco Wildlife and Ecosystem Research Forest (MWERF) and the Panther Run Tract ( $38^{\circ} 42^{\prime} \mathrm{N}$ latitude, $80^{\circ} 3^{\prime} \mathrm{W}$ longitude) in the unglaciated Allegheny Mountain and Plateau physiographic province (Fenneman, 1938), in southwestern Randolph County, West Virginia. The MWERF is a 3413 ha forested area, set aside in 1994 to study the ecological effects of industrial forest management practices. The Panther Run tract, also owned by MeadWestvaco Corporation, is located $16 \mathrm{~km}$ to the north and has an area of approximately 1705 ha. Topography consisted of narrow valleys containing high-gradient streams, and steep slopes topped by broad ridges that ran in a south-southwest to northnortheasterly direction. The management area is divided into stands ranging in size from approximately 1-130 ha, with the majority approximately10-20 ha. Typical timber management practices were even-aged regeneration harvesting and various partial harvesting techniques. Other management activities included: road building associated with harvesting, mowing and seeding roadsides, maintaining grassy areas around gas wells, and planting wildlife food plots.

Below $850 \mathrm{~m}$, cove hardwood and mixed mesophytic plant communities dominated in intact, predominantly closed-canopy forest areas, including species such as northern red oak (Quercus rubra L.), white ash (Fraxinus americana L.), American basswood (Tilia americana 
L.), cucumber magnolia (Magnolia acuminata L.), black birch (Betula lenta L.), and tulip-poplar (Liriodendron tulipifera L.), with an understory of American beech (Fagus grandifolia Ehrh.) and red maple (Acer rubrum L.). Xeric oak-hickory (Quercus-Carya) communities also occurred at low elevations. Elevations from $850-1000 \mathrm{~m}$ were dominated by northern hardwoods such as red maple, sugar maple (A. saccharum L.), American beech, yellow birch (B. allegheniensis Michx.), black cherry (Prunus serotina Ehrh.), and Fraser's magnolia (M. fraseri Walt.). Vegetation in areas $>1000 \mathrm{~m}$ was characterized by mixed stands of northern hardwoods, red spruce (Picea rubens Sarg.), and eastern hemlock (Tsuga canadensis Carr.). Present in riparian areas were eastern hemlock, red spruce, and great rhododendron (Rhododendron maximum L.). A few small stands of mature white pine (Pinus strobus L.) covered reclaimed strip mines. Most intact forest areas had a fairly open understory, a greenbrier (Smilax spp.) shrub layer, and a dense ground cover of hay-scented fern (Dennstaedtia punctilobula Michx), as a result of high rates of deer herbivory (Hicks, 1998).

Even-aged regeneration harvests that ranged in age from zero to nine years post-harvest made up about $10 \%$ of the site (Table 1). The harvests ranged from those completely that removed all trees $>2.5 \mathrm{~cm}$ d.b.h., to those with a few randomly scattered residual large-diameter trees, to deferment cuts (Smith et al., 1989) in which residual trees were evenly spaced throughout the stand. Regeneration in all even-aged harvests consisted primarily of Rubus, fire cherry (P. pennsylvanica L.), and stump sprouts of black cherry, tulip-poplar, and red maple. Areas that underwent partial harvests since 2000 had fairly open understories similar to those of closed-canopy forest areas, while the understory layers of stands harvested in the early 1990's were typically very dense. At lower elevations this understory consisted primarily of spicebush 
(Lindera benzoin L.) and American beech saplings, and at middle elevations it consisted of a shrub layer of greenbrier.

\subsection{Land cover}

For each year of the study, five categories of land cover were digitized on 1997 digital ortho-photoquads of the study sites using ArcView $3.2^{\odot}$ : deciduous mature forest (DM), mixed mature forest (MM), deciduous partial cut (DP), mixed partial cut (MP), and even-aged regeneration harvest $(\mathrm{RH})$ (Table 1). Shapefiles provided by MeadWestvaco aided in interpretation of the aerial photographs. Final land cover maps were corrected to reflect changes to the landscape after 1997. Deciduous forest was composed entirely of hardwoods, or hardwoods with a few isolated conifers present (approximately $<1$ tree/ha); mixed forest had conifers scattered throughout or in stands of hemlock along streams. Mature forest stands originated in the 1920's and received diameter limit cutting no more recently than the 1980's (P. D. Keyser, MeadWestvaco Corporation, pers. comm.). Even-aged regeneration harvests occurred from 1994-2003, and removed most trees $>2.54 \mathrm{~cm}$ from areas approximately 20 ha in size; $2-4 \mathrm{~m}^{2}$ ba/ha (7-20\% of the original stand) was left behind in some even-aged harvests, for aesthetic and wildlife value. Partial harvests occurred from 1990-2003 and removed single canopy trees (typically $>30 \mathrm{~cm}$ diameter at breast height), leaving approximately $16 \mathrm{~m}^{2} \mathrm{ba} / \mathrm{ha}$, or $70-80 \%$ of the original stand in place. The total area of each land cover type was calculated for each year of the study. 


\subsection{Thrush occurrence}

In 2001, birds were surveyed at 108 point count stations at the MWERF. During 20022003, 54 points were added at the Panther Run Tract for a total of 162 points. The points were a subset of existing points set up on a $241 \mathrm{~m}$ by $241 \mathrm{~m}$ grid system by MeadWestvaco for vegetation inventory purposes, and were distributed evenly across the study sites. Most bird survey points were approximately $241 \mathrm{~m}$ apart, while others were approximately $482 \mathrm{~m}$ apart. Each point was marked with a uniquely numbered $1 \mathrm{~m}$ by $1 \mathrm{~cm}$ aluminum stake. The $50-\mathrm{m}$ radius around each point count station was classified into the five land cover categories using GIS software and field observations. If the 50-m radius included both an even-aged harvest and either mature forest or partially harvested forest, it was classified as edge.

Bird surveys were conducted using a standard 50-m radius point count method (Ralph et al., 1993). Points were sampled from 30 May to 4 July, the time in West Virginia after which most spring migrants have left the area and before the resident species have completed their nesting cycles (Hall, 1983). The counts were conducted from $1 / 2$ hour after until four hours after sunrise (approximately 0530 to $0900 \mathrm{~h}$ EST) on days without significant precipitation and with wind speeds of less than $19 \mathrm{~km}$ per hour. Each thrush species was recorded as being present or absent within a 50-m radius centered on the inventory point when initially detected. Although the accuracy of estimating relative abundances using standard point count methodology has been questioned (Thompson, 2002), we used this method to keep our methods consistent with data collected previously at the study site (Weakland, 2000). To reduce the problem of non-detection of species, points were sampled twice, each time by a separate observer proficient in the visual and aural identification of songbirds. A species was considered present if detected at least once during the two sampling periods. 
We used $\chi^{2}$ contingency table analysis to determine if the distribution of points among land cover categories differed between points used by each species and those available. The amount of each cover type available was considered to be the number of point count stations falling within that type. The amount used was considered to be the number of point count stations within that type at which a species was detected. Because the land cover category of some point count stations changed from year to year as harvesting occurred, and because the number of point count stations increased between 2001-2002, each point count station in each year was considered one available point count. Thus the $\chi^{2}$ statistic would equal zero if a species were detected at point count stations within the cover types in the same proportion in which each was available. Because the wood thrush is partially segregated from the hermit thrush by altitude in West Virginia (Hall, 1983; Dellinger 2005, Chap 2), only a portion of the study area could be considered actually available to these two species. Therefore, the availability of each land cover category was calculated separately for the hermit thrush and wood thrush, using only those point count stations that occurred above $997 \mathrm{~m}$ for the hermit thrush and below $823 \mathrm{~m}$ for the wood thrush; these elevations corresponded to the minimum and maximum altitudinal ranges at which each species was detected, respectively. The American robin and veery had wide elevational ranges; thus all point count stations were considered available to them. We assumed no other variables varied among point count stations that would limit their availability to any of the species. We then calculated Bonferroni 95\% confidence intervals for each species (Neu et al., 1974). Based on this method, if the proportion of available point count stations within each land cover fell within the $95 \%$ confidence interval of the species' occurrence, the species was considered to demonstrate no selection for or against the cover type. If it was greater than the upper end of the confidence interval the species was considered to select against the land cover, 
and if less than the lower end the species was considered to select for it. We considered this method to be most appropriate for our data set, which contained limited observations of a large number of individuals (White and Garrott, 1990).

A logistic regression model was constructed for each thrush species to examine relations among changes in species occurrence and changes in the amount of each land cover category over time. The dependent variable of each model was the presence or absence of each species at each point count station during each year of the study. The independent variables were the percents of each land cover type present each year. To simplify the models, deciduous and mixed mature forests were combined into one category, and deciduous and mixed partial harvests were combined into another, resulting in three forest cover types: mature forest (MF), partial harvests $(\mathrm{PH})$, and even-aged regeneration harvests $(\mathrm{RH})$. Year and elevation were used as blocking factors to adjust for variability in species occurrence due to normal yearly variations in population size and differences in occurrence due to elevational ranges of the species (Dellinger, 2005, Ch. 2). We used the stepwise procedure (SAS ${ }^{\circledR}$ Institute, 2004) to determine which variables were related to survival, and the Wald $\chi^{2}$ test to test for their significance. The model Goodness-of-Fit $\chi^{2}$ test $\left(G_{\mathrm{M}}\right)$ (Hosmer and Lemeshow, 1989) was used to test the model's fit to the data. An $\alpha$ level of 0.15 was chosen to enter and keep variables in the model during the stepwise procedure.

\section{$2.4 \quad$ Nest survival}

We searched for nests of the four thrush species within 18 20-ha plots distributed across the study sites. All plots were oriented across the elevation gradient to reflect the steeply sloping nature of the landscape and to avoid being overly concentrated in either ridges or valleys. We 
also searched for nests near the 162 point count stations where thrushes were detected during surveys. These methods were used to systematize our search efforts and avoid finding only those nests that were most visually obvious. Nests were located using techniques summarized by Martin and Guepel (1993), including systematically searching likely areas, listening for begging chicks, and observing the behavior of adult birds.

We revisited nests every two to three days to determine the success at each developmental stage. Nests that fledged at least one chick were considered successful. Circumstantial evidence for a successful nest included observations of nestlings within two days of the average fledging age for the species (after Whitcomb et al., 1981; Ehrlich et al., 1988), alterations to the nest structure indicative of fledging, observations of fledglings near the nest, or of parents with fledglings in the general vicinity of the nest. Evidence for a failed nest included signs of predation or disappearance of the nest, eggs, adults, or nestlings before the average age of fledging for the species. If insufficient evidence was found from which to draw a conclusion, the fate of the nest was recorded as unknown and the last exposure day was recorded as the last time activity was observed at the nest (Manolis et al., 2000).

We assumed that each nest was built by a separate breeding pair, and considered the nest to be our experimental unit. Nests were plotted on a map and assigned to one of the five land cover categories. The Mayfield method (Mayfield, 1961; 1975) was used to calculate daily survival rates for each nest. Estimates were calculated separately for the incubation and brood periods because nest survival may differ between the two periods. Total survival estimates for the entire nesting period were then determined by multiplying survival rates of the periods (Mayfield, 1975). Source of nest failure also was documented for each land cover. Survival was compared among years and land cover types for individual species and for all species combined 
using CONTRAST ${ }^{\circledR}$ (Hines and Sauer, 1989), a multiple comparison $\chi^{2}$ test used to compare survival estimates.

To examine relations among changes in nest survival with changes in the amount of each land cover category on the study site over time, a "Mayfield logistic regression" model was constructed for each species after the methods of Hazler (2004). Because nest survival did not differ among species, models also were constructed for nests of all species combined. The dependent variable in each model was the Mayfield estimator of nest survival (Mayfield 1961, 1975) expressed in $\mathrm{SAS}^{\circledR}\left(\mathrm{SAS}^{\circledR}\right.$ Institute 2004) as FAILURE / DAYS OBSERVED (Hazler 2004), where FAILURE was a binary variable and DAYS OBSERVED was the number of days the nest was monitored. Independent variables were the percent of each land cover type each year. Deciduous and mixed forest types were combined to simplify the models. Year and elevation were used as blocking factors to adjust for variability in nest placement or survival due to yearly variation and elevational ranges (Dellinger, 2005, Ch.2). We used the stepwise procedure (SAS ${ }^{\circledR}$ Institute, 2004) to determine which variables were related to survival, and the Wald $\chi^{2}$ test to test for their significance. The model Goodness-of-Fit $\chi^{2}$ test $\left(G_{M}\right)$ (Hosmer and Lemeshow, 1989) was used to test the model's fit to the data. An $\alpha$ level of 0.15 was chosen to enter and keep variables in the model during the stepwise procedure.

\subsection{Microhabitat}

We sampled 21 variables (Table 2) using methods modified from James and Shugart (1970) and BBIRD protocols (Martin et al., 1997) in 0.04 ha circular plots centered at all nests monitored. These variables were: average canopy height, distance to nearest edge, percent slope, aspect of the plot, percent of six ground cover categories, percent of six canopy height 
categories, density of four diameter classes of trees, and density of snags. For nests monitored during 2002-2003, vegetation also was sampled at a randomly located plot between 30-100 m from each nest in a randomly chosen distance and direction. This distance was chosen to increase the likelihood that our random plots reflected a potential nest site actually available to the pair (Jones, 2001), because it reflected the size of an average thrush territory (Howell, 1942; Weaver, 1949; Martin, 1960; Bertin, 1975; Pitts, 1984). Each random plot also was located in the same land cover category as its corresponding nest site.

Before analyses, aspect was transformed using Beers et al. (1966) transformation: $A^{\prime}=$ $\cos (45-\mathrm{A})+1$. Values can range from 0 to 2 , with 2 indicating northeast facing slopes and 0 indicating southwest facing slopes (Beers et al., 1966). Slope, percent ground and canopy cover were transformed with an arcsine square root transformation, and number of trees with a square root transformation prior to analysis. Nests were not analyzed separately by year due to small sample sizes. We felt this combination of the data by year was justified because it has been suggested that the nest site selection behavior of a bird species has been fixed by evolutionary processes and thus the microhabitat used for nest placement should not vary by year (Rosenzweig, 1981; Martin, 1988).

To characterize the microhabitat available within each land cover category, we examined differences in the vegetation structure among the random plots sampled in each category using multivariate analysis of variance (MANOVA) (Barker and Barker, 1984) and one-way analysis of variance (ANOVA, Dowdy and Wearden, 1983) with post-hoc comparisons using the WallerDuncan k-ratio $t$-test (SAS ${ }^{\circledR}$ Institute, 2004). The independent variable was land cover category (MF, $\mathrm{RH}$, or $\mathrm{PH}$ ) and the dependent variables were the 21 habitat variables measured. 
To determine if the nest site of each species differed from the surrounding stand, variables sampled at nests within each land cover category were compared to variables at their corresponding randomly located plots using paired $t$-tests (Dowdy and Wearden, 1983).

Separate analyses were completed for each species within each land cover.

To determine if each species chose similar microhabitats regardless of the land cover category in which it nested; or, conversely, if it chose a different microhabitat depending on the land cover, a three-way ANOVA with post-hoc comparisons using the Waller-Duncan k-ratio $t$ test $\left(\mathrm{SAS}^{\circledR}\right.$ Institute, 2004) identified the specific variables that differed among the nests of each species across different land covers. Land cover (MF, $\mathrm{RH}$, or $\mathrm{PH})$ was the independent variable and the dependent variables in each ANOVA model were the microhabitat variables sampled at each nest site (Table 2).

A "Mayfield logistic regression" model was constructed for each species using the methods of Hazler (2004) described above. The independent variables were the 21 microhabitat variables sampled at each nest site. Year and elevation were used as blocking factors to adjust for variability in nest placement or survival due to yearly variation in weather conditions and elevational ranges.

\section{Results}

\subsection{Species occurrence}

For each species, habitat use differed from availability (American robin, $\mathrm{df}=5, \chi^{2}=$ 15.75, $P<0.01$; hermit thrush, $\mathrm{df}=5, \chi^{2}=27.26, P<0.01$; veery, $\mathrm{df}=5, \chi^{2}=23.45, P<0.01$; wood thrush, $\left.\mathrm{df}=5, \chi^{2}=20.07, P<0.01\right)$. American robins and veeries selected against DP and did not select for or against any other land cover (Table 3). In contrast, wood thrushes selected 
for DP. Hermit thrushes selected for MM and selected against RH, edge, DM, and DP. No other species selected for or against $\mathrm{RH}, \mathrm{PH}$, or edge.

Occurrence of wood thrushes was positively related to increasing amounts of $\mathrm{PH}\left(B_{o}=\right.$ $0.08, \mathrm{SE}=0.04$, Wald $\chi^{2}=5.25, P=0.02 ; G_{\mathrm{M}}=2.17$, d.f. $=1, P=0.02$ ). No relations were detected $(P>0.05)$ among the changes in land cover categories during 2001-2003 and changes in occurrence of the American robin, hermit thrush, or veery, and there was no year effect $(P>$ $0.05)$ for any species.

\subsection{Nest survival}

During the 3 years of the study, 141 nests were found and monitored: 17 American Robin, 28 Hermit Thrush, 46 Veery, and 50 Wood Thrush. Ninety were monitored within designated nest-searching plots and 51 were monitored outside the plots, found either during searches near point count stations or found incidentally. We determined fate of 128 nests and used these to calculate nest survival. No differences were found among years for all species combined $(P>0.05)$. The small number of nests found in 2001 precluded a comparison with other years for each species individually, but species-specific nest survival did not differ between 2002 and 2003. Survival rates of nests of each species found within designated nest-searching plots and those found elsewhere also did not differ. Thus, on and off-plot nests as well as years were pooled for analyses. Nest survival rates of the American robin, hermit thrush, veery and wood thrush were $39 \%, 28 \%, 34 \%$, and $21 \%$, respectively, and did not differ among species $\left(\chi^{2}\right.$ $=4.57, P=0.44)$.

Nest survival for 128 nests was greatest in RH for the American robin, veery, and wood thrush (Table 4) although sample size of nests in this land cover was small $(n=14)$. The 
American robin, hermit thrush, and veery had greater nest survival in MF than in PH; the wood thrush had the opposite pattern, with greater nest survival in PH than in MF. No nests were found within $11.3 \mathrm{~m}$ of an edge. Of 73 nests for which failure was determined, nest predation was known to occur in 65 of them. Five nests were abandoned by the adults for unknown reasons during the incubation period: one American robin nest in MP, one veery nest in MD, and one veery and two hermit thrush nests in MM. The cause of failure could not be determined for three nests.

No relations were detected $(P>0.05)$ using Mayfield logistic regression analysis between the changes in the amount of each land cover category present at the study sites during 20012003 and changes in survival rates of any individual species or of all species combined. No effects on survival were detected due to year or elevation.

\subsection{Microhabitat variables}

No difference was detected in the overall microhabitat of the land covers sampled at randomly located plots (Wilk's $\lambda=0.61, \mathrm{~F}=1.43, P=0.06$ ) although seven of 21 microhabitat variables sampled differed $(P<0.05)$ among land cover categories (Table 5). Canopy cover from 6-24 $\mathrm{m}$ ranged from $0-95 \%$ within $\mathrm{RH}$, and was dependent upon proximity of the vegetation sampling plot to residual overstory trees in the stand. RH differed from MF and PH in having a lower density of small trees, more $3 \mathrm{~m}$ canopy and less 6-18 $\mathrm{m}$ canopy present. Additionally, RH had lower average canopy height and greater sapling density than MF, and had less bare ground than $\mathrm{PH}$. PH differed from MF only in having greater sapling density.

For all species, nest sites in MF had the greatest number of variables that differed between nest sites and their corresponding random plots (Table 6). There was less leaf litter and 
more moss ground cover at American robin and hermit thrush nest sites in MF than at random plots. American robins also had more herbaceous ground cover and hermit thrushes had less woody debris. There was less 12-18 m canopy cover at nest sites of all species except the veery, which had less 18-24 m canopy. Hermit thrush nest sites also had a slightly lower average canopy height and less canopy cover from 3-24 m than did random plots. Hermit thrushes, veeries, and wood thrushes had higher sapling densities at their nest sites, while American robins had a lower density of trees $>7.6 \mathrm{~cm}$ dbh. For nest sites located within $\mathrm{RH}$, those of the American robin had more $3 \mathrm{~m}$ canopy cover and those of the wood thrush had less moss ground cover. In $\mathrm{PH}$, veery nest sites had more $3 \mathrm{~m}$ canopy cover and fewer $23-38 \mathrm{~cm}$ dbh trees present than did randomly located plots; nest sites of the other three species in $\mathrm{PH}$ did not differ from random.

MANOVA detected no difference in the overall microhabitat of hermit thrush nest sites between mature forest and sawtimber harvests (Wilk's $\lambda=0.14, \mathrm{~F}=2.07, P=0.16$ ), although ANOVA indicated that Hermit thrush nest sites in PH were farther from edges and had more large diameter trees and saplings than did those in MF (Table 7); no nests were located in RH. American robin nest sites placed in different land cover categories were similar in all variables measured except for the presence of three canopy height layers, which varied among land covers; small sample size precluded multivariate analysis. The overall microhabitats of veery and wood thrush nest sites differed among land covers (Wilk's $\lambda=0.145, \mathrm{~F}=1.73, P=0.03$; Wilk's $\lambda=$ $0.19, \mathrm{~F}=1.66, P=0.04)$. Nine individual variables differed among land covers at veery nest sites, although only two differed between MF and PH. Similarly, at wood thrush nest sites, nine variables differed among the land covers, but only one between MF and PH (Table 7). 
In MF, veery nest survival was positively correlated with litter groundcover $\left(B_{o}=5.08\right.$, $\mathrm{SE}=1.77$, Wald $\chi^{2}=8.26, P<0.01 ; G_{\mathrm{M}}=8.72$, d.f. $\left.=8, P=0.37\right)$ and negatively with large trees $\left(B_{o}=-2.30, \mathrm{SE}=0.92\right.$, Wald $\chi^{2}=6.25, P=0.01 ; G_{\mathrm{M}}=8.72$, d.f. $\left.=8, P=0.37\right)$. American robin nest survival in MF was negatively correlated with bare ground $\left(B_{o}=-7.04, \mathrm{SE}=3.45\right.$, Wald $\chi^{2}=15.03, P<0.01 ; G_{\mathrm{M}}=3.60$, d.f. $\left.=2, P=0.17\right)$, as was aspect for hermit thrushes $\left(B_{o}=\right.$ $-1.33, \mathrm{SE}=0.48$, Wald $\chi^{2}=7.85, P<0.01 ; G_{\mathrm{M}}=12.42$, d.f. $\left.=8, P=0.13\right)$. Wood thrush nest survival was positively correlated with canopy height in $\mathrm{PH}\left(B_{o}=0.40, \mathrm{SE}=0.12\right.$, Wald $\chi^{2}=$ $11.29, P<0.01 ; G_{\mathrm{M}}=0.91$, d.f. $\left.=3, P=0.82\right)$.

\section{Discussion}

\subsection{Even-aged regeneration harvesting}

Wood thrush and veery are considered area-sensitive birds that dwell in the forest interior (Heckert 1995, Robbins et al. 1989), and their breeding habitats generally have been characterized as completely (Crawford et al., 1981; Hall, 1983) or mostly closed-canopy forests (Moskoff 1995, Roth et al. 1996). While these descriptions were accurate for the majority of nests we monitored, we also found nine wood thrush and four veery nests within regenerating even-aged harvests four to nine years post-harvest. The veery's use of dense shrubs for nesting is fairly well-known (Moskoff, 1995; Heckscher, 2004), and the occasional use of early successional vegetation by adult wood thrushes for nesting and foraging also has been documented (Annand and Thompson, 1997; Pagen et al., 2000; Marshall et al., 2003). The use of such areas by wood thrush and veery calls into question their dependence upon closed-canopy forest for breeding. Based on frequency of occurrence, no species selected for even-aged harvests and few nests were found within them, which may reflect their low availability $(<10 \%$ 
of total area) at the study site. But for those nests monitored within this land cover, there was an increase in nest survival. This increase in survival has been observed previously (King et al., 2001), and has been attributed to a reduction in the number of predators within clearcut stands (King et al., 1998) or to a predator's difficulty maneuvering within them (Anders et. al, 1998; Marshall et al., 2003). Thus, nesting can be successful within harvested stands. However, a larger number of nests monitored in this land cover would be necessary to determine the full affect on nest survival; likewise, this effect may change as harvesting continues and a larger proportion of the landscape is converted to young, even-aged stands.

Twelve of 13 wood thrush and veery nest sites within even-aged harvests were characterized by having at least one tree $>18 \mathrm{~m}$ in height within $11.3 \mathrm{~m}$ of the nest. Eleven nests were in deferment harvests and one was in a clearcut containing small groups of residual canopy trees. Because none of the thrushes are canopy nesters that would use such trees for nest placement, it is not clear what role, if any, the residual trees may have played in wood thrush and veery nest site selection. One possible explanation is that the trees could have been used for singing perches. Heckscher (2004) suggested previous descriptions of veery habitat in closedcanopy forest may have reflected the species' singing rather than nesting habitat. A second possibility is that tall canopy trees were a factor in nest site selection, possibly even to the extent of changing what would otherwise have been seen by the birds as an unsuitable stand into what they perceived as potential nesting habitat. Bertin (1977) suggested wood thrushes require at least one tree $>12 \mathrm{~m}$ in height within their nesting area; perhaps one such tree is all that is required to stimulate nesting. However, we did not address nest site selection behavior in our study, only habitat use. 
Although our observation of large trees at nest sites could provide an argument for the management practice of leaving residual trees within clearcuts, the presence of a single large tree above a thrush nest also could decrease the nest's chance of survival by providing a perch for avian predators (Yahner and Wright, 1985) and/or brown-headed cowbirds, who might use them to watch the parents and locate the nest. For example, in some songbird species, cowbird nest success was greater at nest sites with more trees (Freeman et al., 1990) and at nests with more overhead foliage (Larison et al., 1998). Furthermore, Duguay et al. (2001) documented greater nest parasitism rates associated with deferment harvests. This scenario does not appear to be the case in our study, because the nests we monitored in even-aged harvests had excellent survival rates; however, the rate of nest parasitism was low throughout the study area and was never observed in thrushes within any land cover. Little research has been done regarding the value to wildlife of residual trees within otherwise clearcut stands (Taulman et al., 1998; Weakland, 2000; Duguay et al., 2001), and more study is necessary regarding the spatial distribution and density of residual trees within clearcuts and deferment cuts and their affects on avian nest survival before making management recommendations.

Our observations of hermit thrushes were consistent with those of other authors (eg., Freedman et al., 1981, Manolis et al., 2002) in that hermit thrushes never were detected and no nests were found within an even-aged harvest of any age, and individuals were only twice observed near a harvested edge. Both observations were of singing males at the edge of cuts implemented during the previous winter, but none were present at the same location during the two following years. Some hermit thrushes have year to year nest site fidelity (DeSante, 1990) so it is possible that the individuals near the even-aged harvests had nested in these stands prior to their being harvested, had returned, and were attempting to nest in the same or in a nearby 
location. If they were unsuccessful at breeding in 2001, their lack of success may have kept them from returning in subsequent years, a behavior suggested for other songbird species (Blancher and Robertson, 1985).

Also consistent with other authors were our observations of hermit thrush nests in areas disturbed in secondary ways by logging activities, such as on skidder trails and log landings (Jones and Donovan, 1996), many directly on constructed water-breaks. Other nests were

located near the forest edge on open-canopy banks created by road building. Thus the practice of seeding roadside banks and skidder trails may be of benefit to the hermit thrush and help mitigate habitat loss from road building and provide nesting habitat once a forest has regenerated after harvesting. Occasional mowing could maintain such areas of herbaceous groundcover and short woody saplings.

\subsection{Partial harvesting}

Our study suggests a positive relation existed between wood thrushes and partial harvesting. Existence of this relation was supported directly by occurrence of wood thrushes within deciduous partial harvests more often than expected by the proportion of this land cover at the study site; by an increase in wood thrush occurrence as percent of partial harvests increased; and by higher wood thrush nest survival in partial harvests than in mature forest. Indirectly, the relation was supported by the observation that wood thrushes nesting in mature forest selected nest sites with more saplings than random. This finding is potentially important because greater small stem density was the only microhabitat difference detected between mature forest and partial harvests. Thus, by creating canopy gaps and allowing for areas of dense regeneration, partial harvesting supplied for the wood thrush the sapling density that mature forest lacked. 
Unlike wood thrush, American robin, hermit thrush, and veery selected against partial harvests and had lower nest survival within them than they did in mature forest. However, no significant relations were detected at the landscape or microhabitat scale between this land cover and nest survival of any of the three species, so the reason for their lowered fitness within it is unclear. In mature forest, veery and hermit thrush both selected microhabitats for nesting with denser saplings than random, so it is not likely that the increased regeneration present in partial harvests deterred them. One possible explanation is that of interspecific competition with wood thrushes, which might have forced them out of their territories or interfered with their nesting or foraging activities. Agonistic interactions among thrush species have been documented elsewhere (Dilger, 1956b), and it has been suggested that the wood thrush is socially dominant to the veery and hermit thrush (Morse 1971; 1974). Because interspecific competition only occurs when resources are limited (Weins, 1984), the existence of competition would suggest that partial harvesting is somehow limiting nesting habitat or resources for the guild. However, our study did not address competition among the species, so additional research is necessary to answer the question of why partial harvesting is apparently beneficial for the wood thrush but not for other members of its guild.

Similar to previous studies that have found partial harvesting to have little effect on songbirds in forested landscapes (Lent and Capen, 1995; Weakland et al., 2002), no species selected for or against areas of partial harvesting in mixed forests. American robins and hermit thrushes nested in regenerating red spruce saplings, but these tended to be in open-canopy areas along roadsides in mature forest areas, rather than in closed-canopy partially harvested areas. Although wood thrushes in other parts of the Appalachians commonly nest in small eastern hemlocks (Farnsworth and Simons, 1999), only one such nest was found in this study. Thus 
partial harvesting in mixed forest may have little effect on forest songbirds, while the same treatment in deciduous forest is beneficial for wood thrush.

\section{Conclusions}

Nest survival rates of all four species fell within the range of or surpassed those reported by other published studies of nest survival in eastern forests using the Mayfield method. These recorded ranges in nest survival were: $20-60 \%$ for American robin, $10-29 \%$ for hermit thrush, $14-74 \%$ for veery, and 21-54\% for wood thrush (Burke and Nol, 2000; Dececco et al., 2000; Duguay et al., 2001; Martin et al., 2004). The data presented here lend support to the suggestion by Thompson (1993) that forest management and forest songbird conservation are not mutually exclusive activities and suggest the forested landscape was still suitable habitat for thrushes despite the disturbance of logging. The age post-harvest at which an even-aged stand becomes suitable for hermit thrushes, however, as well as the amount of mature forest in the larger landscape required by each species, should be determined by continued monitoring. This information then could be used when implementing forest management for the wood thrush and other members of its guild. It is likely that wood thrush will increase in abundance and hermit thrush decrease as forest disturbance continues.

Finally, for the purposes of this study, all techniques that removed single large diameter trees and created canopy gaps were considered equally under the term partial harvesting. We acknowledge, however, that the effects of various single-tree harvesting practices may have differing effects on the overall health and value of the forest (Fajvan et al., 1998) and we do not advocate the use of silviculturally unsound techniques in forest management such as the high grading of timber. Instead, if an increase in sapling density is desired to enhance habitat for 
nesting wood thrushes, we recommend techniques such as crown thinning or a switch to unevenaged management.

\section{References}

Anders, A.D., Faaborg, J., Thompson, F.R., 1998. Post-fledging dispersal, habitat use, and home range size of Wood Thrushes. Auk 115, 349-358.

Annand, E.M., Thompson III, F.R., 1997. Forest bird response to regeneration practices in central hardwood forests. J. Wildl. Manage. 61, 159-171.

Barker, H.R., Barker, B.M., 1984. Multivariate Analysis of Variance (MANOVA): A Practical Guide to its Use in Scientific Decision Making. University of Alabama Press, Birmingham.

Beers, T.W., Dress, P.E., Wensel, L.C., 1966. Aspect transformation in site productivity research. J. Forest. 64, 691-692.

Bertin, R.I., 1975. Factors influencing the distribution of the wood thrush and veery in western Connecticut woodland. Master's thesis, University of Connecticut, Storrs, CT, USA.

Bertin, R.I, 1977. Breeding habitats of the wood thrush and veery. Condor 79, 303-311.

Blancher, P.J., Robertson, R.J., 1985. Site consistency in kingbird breeding performance, implications for site fidelity. J. Anim. Ecol. 54, 1017-1027.

Bourque, J., Villard, M.-A., 2003. Effects of selection cutting and landscape-scale harvesting on the reproductive success of two Neotropical migrant bird species. Conserv. Biol. 15, 184195.

Burke, D.M., Nol, E., 2000. Landscape and fragment size effects on reproductive success of forest-breeding birds in Ontario. Ecol. Appl. 10, 1749-1761.

Crawford, H.S., Hooper, R.G., Titterington, R.W., 1981. Songbird population response to silvicultural practices in central Appalachian hardwoods. J. Wildl. Manage. 45,680-692.

Dececco, J.A., Marshall, M.A., Williams, A.B., Gale, G.A., Cooper, R.J., 2000. Comparative seasonal fecundity of four Neotropical migrants in middle Appalachia. Condor 102, 653663.

Dellinger, R.L., 2005. Nesting success and nest site characteristics of four thrush species on a managed, central Appalachian forest. Doctoral dissertation, West Virginia University, Morgantown, WV, USA. 
DeSante, D.F., 1990. The role of recruitment in the dynamics of a Sierran subalpine bird community. Am. Natural. 136, 429-445.

Dilger, W.C., 1956a. Adaptive modification and ecological isolating mechanisms in the thrush genera Catharus and Hylocichla. Wilson Bull. 68, 171-199.

Dilger, W.C., 1956b. Hostile behavior and reproductive isolating mechanisms in the avian genera Catharus and Hylocichla. Auk 73, 313-353.

Dowdy, S., Wearden, S., 1983. Statistics for Research. Wiley, New York.

Duguay, J.P., Wood, P.B., 2000. Effects of timber harvests on invertebrate biomass and avian nest success. Wildl. Soc. Bull. 28, 1123-1131.

Duguay, J.P., Wood, P.B., Nichols, J.V., 2001. Songbird abundance and avian nest survival rates in forests fragmented by different silvicultural treatments. Conserv. Biol. 15, 1405-1415.

Ehrlich, P.R., Dobkin, D.S., Wheye, D., 1988. The Birder's Handbook. Simon and Schuster Inc., New York.

Fajvan, M.A., Grushecky, S. T., Hassler, C.C., 1998. The effects of harvesting practices on West Virginia's wood supply. J. Forest. 96, 33-39.

Farnsworth, G.I, Simons, T.R., 1999. Factors affecting nesting success of Wood Thrushes in Great Smoky Mountains National Park. Auk 116, 1075-1082.

Fenneman, N.M., 1938. Physiography of the Eastern United States. McGraw-Hill, New York.

Fenske-Crawford, T.J., Niemi, G. J., 1997. Predation of artificial ground nests at two types of edges in a forest-dominated landscape. Condor 99, 14-24.

Flaspohler, D.J., Temple, S.A., Rosenfeld, R. N., 2001. Species specific edge effects on nest succes and breeding bird density in a forested landscape. Ecol. Appl. 11, 32-46.

Freedman, B.C., McLaren, I.A., Tingley, S.I., 1981. Forestry management practices and populations of breeding birds in a hardwood forest in Nova Scotia. Canad. Field Natur. 95, 307-311.

Freeman, S., Gori, D.F., Rohwer, S., 1990. Red-winged Blackbirds and Brown-headed Cowbirds: some aspects of a host-parasite relationship. Condor 92, 336-340.

Gross, A.O., 1949. Eastern Hermit Thrush. In: Bent, A.C. (Ed.), Life Histories of North American Thrushes, Kinglets, and their Allies. United States National Museum Bulletin 196, Washington, D.C., pp.143-162.

Hagan, J.M., Vander Haegen, W.M., McKinley, P.S., 1996. The early development of forest fragmentation effects on birds. Conserv. Biol. 10, 188-202. 
Hall, G.A., 1983. West Virginia Birds. Carnegie Museum of Natural History, Pittsburgh.

Hall, G.A., 1984. A long-term bird population study in an Appalachian spruce forest. Wilson Bull. 96, 228-240.

Hamel, P.B. 1992. Land Manager's Guide to the Birds of the South. The Nature Conservancy, Southeastern Region, Chapel Hill.

Hanski, I.K., Fenske, T.J., Niemi, G.J., 1996. Lack of edge effect in nesting success of breeding birds in managed forest landscapes. Auk 113, 578-585.

Hartley, M.D., Hunter, M.L. Jr., 1998. A meta-analysis of forest cover, edge effects and artificial nest predation rates. Conserv. Biol. 12, 465-469.

Haskell, D.G., 2000. Effects of forest roads on macroinvertebrate soil fauna of the southern Appalachian Mountains. Conserv. Biol. 14, 57-63.

Hazler, K.R., 2004. Mayfield logistic regression: a practical approach for analysis of nest survival. Auk 121, 707-716.

Heckert, J.R., 1995. Status and habitat area requirements of the Veery in Illinois. Auk 112, 794797.

Heckscher, C.M., 2004. Veery nest sites in a mid-Atlantic piedmont forest, vegetative physiognomy and use of alien shrubs. Am. Midl. Natur. 151, 326-337.

Hicks, R.R. Jr., 1998. Ecology and Management of Central Hardwood Forests. John Wiley, New York.

Hines, J.E, Sauer, J.R., 1989. Program CONTRAST-A General Program for the Analysis of Several Survival or Recovery Rate Estimates. US Fish \& Wildlife Service, Fish \& Wildlife Technical Report 24, Washington, DC. http,//www.mbrpwrc.usgs.gov/software.html\#contrast.

Hobson, K.A., Schieck, J., 1999. Changes in bird communities in boreal mixedwood forest, harvest and wildlife effects over 30 years. Ecol.Appl. 9, 849-863.

Hosmer, D.W., Lemeshow, S., 1989. Applied Logistic Regression. John Wiley and Sons, New York.

Howell, J.C., 1942, Notes on the nesting habits of the American Robin (Turdus migratorius L.). Am. Midl. Natur. 28, 529-603

James, F.C, Shugart, H.H. 1970. A quantitative method of habitat description. Aud. Field Notes $24,727-736$. 
Jones, J., 2001. Habitat selection studies in avian ecology: a critical review. Auk 118,557-562.

Jones, P.W., Donovan, T.M., 1996. Hermit Thrush (Catharus guttatus). In: Poole, A., Gill, F., (Eds.). The Birds of North America, no. 261. Academy of Natural Sciences, Philadelphia, and American Ornithologists' Union, Washington, D.C.

King, D.I., DeGraaf, R.M., Griffin, C.R., 1998. Edge-related nest predation in clearcut and groupcut stands. Conserv. Biol. 12, 1412-1415.

King, D.I., DeGraaf, R.M., Griffin, C.R., 2001. Productivity of early successional shrubland birds in clearcuts and groupcuts in an eastern deciduous forest. J. Wildl. Manage. 65, $345-350$.

Knight, R.L., 1997. Hermit thrush. In: Nicholson, C.P. (Ed.). Atlas of the Breeding Birds of Tennessee. University of Tennessee Press, Knoxville, pp 379-381.

Lang, J.D., Powell, L.A., Krementz, D.G., Conroy, M.J., 2002. Wood thrush movements and habitat use, effects of forest management for Red-cockaded Woodpeckers. Auk 119, 109123.

Larison, B., Laymon, S.A., Williams, P.L., Smith, T.B., 1998. Song sparrows vs. cowbird brood parasites: Impacts of forest structure and nest-site selection. Condor 100, 93-101.

Lent, R.A., Capen, D.E., 1995. Effects of small-scale habitat disturbance on the ecology of breeding birds in a Vermont (USA) hardwood forest. Ecogr. 18, 97-108.

Manolis, J.C, Anderson, D.E., Cuthbert, F.J., 2000. Uncertain nest fates in songbird studies and variation in Mayfield estimation. Auk 117, 615-626.

Manolis, J.C, Anderson, D.E., Cuthbert, F.J., 2002. Edge effect on nesting success of ground nesting birds near regenerating clearcuts in forest-dominated landscape. Auk 119, 955970.

Marshall, M.R., DeCecco, J.A., Williams, A.B., Gale, G.A., Cooper, R.J., 2003. Use of regenerating clearcuts by late-successional bird species and their young during the postfledging period. For. Ecol. Manage. 183, 127-135.

Martin, K., 1973. Breeding density and reproductive success of robins in relation to habitat structure on logged areas of Vancouver Island, British Columbia. Master's thesis, Univ. of Alberta, Edmonton, Alberta, CANADA.

Martin, N.D., 1960. An analysis of bird populations in relation to forest succession in Algonquin Provincial Park, Ontario. Ecol. 41, 126-240.

Martin, T.E., 1988. On the advantage of being different: nest predation and the coexistence of bird species. Proc. Nat. Acad. Sci. USA. 85, 2196-2199. 
Martin, T.E., Guepel, G.R., 1993. Nest-monitoring plots, methods for locating and monitoring success. J. Field Ornith. 64, 507-519.

Martin, T.E., Paine, C., Conway, C.H., Hochachka, W.M., Allen, P., Jenkins, W., 1997. BBIRD field protocol. Montana Cooperative Wildlife Research Unit, University of Montana, Missoula, http://pica.wru.umt.edu/bbird/

Martin, T.E., Paine, C., Conway, C.H., Hochachka, W.M., Allen, P., Jenkins, W., 2004. BBIRD database. Montana Cooperative Wildlife Research Unit, University of Montana, Missoula, http://pica.wru.umt.edu/bbird/

Mayfield, H.F., 1961. Nesting success calculated from exposure. Wilson Bull. 73, 255-261.

Mayfield, H.F., 1975. Suggestions for calculating nest success. Wilson Bull. 87, 456-466.

Morse, D.H., 1971. Effects of the arrival of a new species upon habitat utilization by two forest thrushes in Maine. Wilson Bull. 83, 57-65.

Morse, D.H., 1974. Niche breadth as a function of social dominance. Am. Natural. 108, 818-830.

Moskoff, W., 1995. Veery (Catharus fuscescens). In: Poole, A., Gill, F. (Eds.). The Birds of North America, no. 142. Academy of Natural Sciences, Philadelphia, and American Ornithologists' Union, Washington, D.C.

Neu, C.W., Byers, C.R., Peek, J.M., Boy, V., 1974. A technique for analysis of utilizationavailability data. J. Wildl. Manage. 38, 541-545.

Noon, B.R.,1981. The distribution of an avian guild along a temperate elevational gradient: the importance and expression of competition. Ecol. Monogr. 51,105-124.

Pagen, R.W., Thompson, F.R., Burhans, D.E., 2000. Breeding and post-breeding habitat use by forest migrant songbirds in the Missouri Ozarks. Condor 102, 738-747.

Paton, P.W.C., 1994. The effect of edge on avian nest success: How strong is the evidence? Conserv. Biol., 8 17-26.

Petranka, J.W., Eldridge, M.E., Haley, K.E., 1993. Effects of timber harvesting on Southern Appalachian salamanders. Conserv. Biol. 7, 363-370.

Petranka, J.W., Brannon, M.P., Hopey, M.E., Smith, C.K., 1994. Effects of timber harvesting on low elevation populations of Southern Appalachian salamanders. For. Ecol. Manage. 67, 135-147.

Pitts, T.D., 1984. Description of American Robin territories in northwest Tennessee. Migr. 55, 16. 
Powell, L.A., Lang, J.D., Conroy, J.J., Krementz., D.G., 2000. Effects of forest management on density, survival, and population growth of wood thrushes. J. Wildl. Manage. 64, 11-23.

Ralph, C.J., Guepel, G.R. Pyle, P. Martin, T.E. Desante, D.F., 1993. Handbook of field methods for monitoring landbirds. U.S. For. Serv. Gen. Tech. Rep. PSW-GTR-144.

Robbins, C.S, Dawson, D.K., Dowell, B.A, 1989. Habitat area requirements of breeding forest birds of the Middle Atlantic States. Wildl. Monogr.103, 1-34.

Robinson, S.K., Thompson III, F.R., Donovan, T.M., Whitehead, D.R., Faaborg, J., 1995. Regional forest fragmentation and the nesting success of migratory birds. Science 267, 1987-1990.

Robinson, W.D., Robinson, S.K., 1999. Effects of selective logging on forest bird populations in a fragmented landscape. Conserv. Biol. 13, 58-66.

Robinson, W.D., Robinson, S.K., 2001. Avian nesting success in a selectively harvested north temperate deciduous forest. Conserv. Biol. 15, 1763-1771.

Rosenberg, K.V., 2003. Partners in Flight landbird conservation plan, physiographic area 12, mid-Atlantic ridge and valley. Version 1.0., http://www.blm.gov/wildlife/pl_12sum.htm

Rosenzweig, M.L., 1981. A theory of habitat selection. Ecol. 62, 327-335.

Roth, R.R, Johnson, M.S., Underwood, T.J., 1996. Wood Thrush (Hylocichla mustelina). In: Poole, A.,Gill, F.(Eds.). The Birds of North America, no. 246. Academy of Natural Sciences, Philadelphia, and American Ornithologists' Union, Washington, D.C.

Sallabanks, R, James, F.C., 1999. American Robin (Turdus migratorius). In: Poole, A.,Gill, F.(Eds.). The Birds of North America, no. 462. Academy of Natural Sciences, Philadelphia, and American Ornithologists' Union, Washington, D.C.

SAS Institute, 2004. Cary, North Carolina.

Sauer, J.R., Hines, J.E., Fallon, J., 2004. The North American Breeding Bird Survey, Results and Analysis 1966-2003. Version 2004.1. USGS Patuxent Wildlife Research Center, Laurel, MD, http://www.mbr-pwrc.usgs.gov/bbs/bbs.html

Smith, H.C., Lamson, N.I., Miller, G.W., 1989. An aesthetic alternative to clearcutting? J. Forest. 87, 14-18.

Taulman, J.F., Smith, K.G., Thill, R.E., 1998. Demographic and behavioral responses of southern flying squirrels to experimental logging in Arkansas. Ecol. Appl. 8, 1144-1155 
Thompson, F.R. III., 1993. Simulated responses of a forest-interior bird population to forest management options in central hardwood forests of the United States. Conserv. Biol. 7, 325-333.

Thompson, W.L., 2002. Towards reliable bird surveys: Acounting for individuals present but not detected. Auk 11, 18-25.

Vega Rivera, J.H., Rappole, J.H., McShea, W.J., Haas, C.A., 1998. Wood thrush postfledging movements and habitat use in northern Virginia. Condor 100, 69-78.

Weakland, C.A. 2000. Effects of diameter-limit and two-age timber harvesting on songbird populations on an industrial forest in central West Virginia. Doctoral dissertation. West Virginia University, Morgantown, WV, USA.

Weakland, C.A., Wood, P.B., Ford, W.M., 2002. Responses of songbirds to diameter-limit cutting in the central Appalachians of West Virginia, USA. For. Ecol. Manage. 155, 115 129.

Weaver, F.G., 1949. Wood Thrush. In: Bent, A.C.(Ed.). Life histories of North American Thrushes, Kinglets, and their Allies. U.S. Natl. Mus. Bull. 196, Washington D.C., pp.101-123.

Weins, J.A., 1984. On understanding a non-equilibrium world: myth and reality in community patterns and processes. In: Strom, D.P., Simberloff, D., Abele, L.G., Thistle, A.B.(Eds.), Ecological Communities: Conceptual Issues and the Evidence. Princeton Univ. Press, Princeton, NJ, pp. 439-457.

Whitcomb, R.F., Robbins, C.S., Lynch, J.F., Whitcomb, B.L., Klimkiewicz, M.K., Bystrak, D., 1981. Effects of forest fragmentation on avifauna of the eastern deciduous forest. In: Burgess, R.L., Sharpe, B.M., (Eds.), Forest Island Dynamics in Man-dominated Landscapes. Springer-Verlag, New York, pp. 125-206.

White, G.C., Garrott, R.A., 1990. Analysis of Wildlife Radio-tracking Data. Academic Press, New York.

Yahner, R.H., Wright, A.L., 1985. Depredation on artificial nests: effects of edge and plot age. J. Wildl. Manage. 49,508-513.

Zettler, J.A., Taylor, M.D., Allen, C.R., Spira, T.P., 2004. Consequences of forest clear-cuts for native and nonindigenous ants (Hymenoptera, Formicidae). Annals Entomol. Soc. Amer. $97,513-518$. 
Table 1. Percent of land cover categories present on the MeadWestvaco Wildlife and Ecosystem Research Forest (MWERF) and the Panther Run Tract, Randolph County, West Virginia during 2001-2003.

\begin{tabular}{lrrr}
\hline Land cover & \multicolumn{3}{c}{ Percent of study area } \\
\cline { 2 - 4 } & $2001^{\mathrm{a}}$ & $2002^{\mathrm{b}}$ & $2003^{\mathrm{b}}$ \\
\hline Even-aged regeneration harvest & 9.31 & 10.1 & 12.1 \\
& & & 55.2 \\
Mature forest & 74.4 & 58.4 & 28.0 \\
$\quad$ Deciduous & 31.8 & 30.4 & 27.1 \\
$\quad$ Mixed & 42.6 & 28.0 & 27.7 \\
& & & 16.5 \\
Partial harvest & 16.4 & 26.7 & 11.2 \\
$\quad$ Deciduous & 3.3 & 15.8 & 10.9 \\
$\quad$ Mixed & 13.1 & &
\end{tabular}

${ }^{\text {a } M W E R F ~ o n l y ~}$

${ }^{\mathrm{b}}$ MWERF and Panther Run 
Table 2. Microhabitat variables measured in 0.04 ha circular plots at the nest sites of four thrush species and at random sites at the MeadWestvaco Wildlife and Ecosystem Research Forest and the Panther Run Tract, Randolph County, West Virginia during 2001-2003.

\begin{tabular}{ll}
\hline Variable & Description \\
\hline Canopy height $(\mathrm{m})$ & Average height of dominant and codominant trees within plot \\
Distance to edge $(\mathrm{m})$ & Distance to nearest edge \\
Slope $(\%)$ & Slope of $5 \mathrm{~m}$ plot centered on nest, measured with a clinometer \\
Aspect & Azimuth directly downhill from nest \\
Ground Cover (\%) & Measured with site tube at 20 points on $11.3 \mathrm{~m}$ transects \\
\hline Herbaceous & Percent of ground within plot covered by vegetation $<0.5 \mathrm{~m}$ in height \\
Litter & Percent of ground within plot covered by leaf litter \\
Woody debris & Percent of ground within plot covered by woody debris \\
Bare & Percent of bare ground within plot \\
Moss & Percent of ground within plot covered by moss \\
Water & Percent of ground within plot covered by permanent or ephemeral streams \\
Canopy Cover (\%) & \\
\hline $3.0 \mathrm{~m}$ & Percent of plot covered by a tree canopy up to $3.0 \mathrm{~m}$ tall \\
$3.1-6.0 \mathrm{~m}$ & Percent of plot covered by a tree canopy $3.1-6.0 \mathrm{~m}$ tall \\
$6.1-12.0 \mathrm{~m}$ & Percent of plot covered by a tree canopy $6.1-12.0 \mathrm{~m}$ tall \\
$12.1-18.0 \mathrm{~m}$ & Percent of plot covered by a tree canopy $12.1-18.0 \mathrm{~m}$ tall \\
$18.1-24.0 \mathrm{~m}$ & Percent of plot covered by a tree canopy $18.1-24.0 \mathrm{~m}$ tall \\
$>24.0 \mathrm{~m}$ & Percent of plot covered by a tree canopy greater than $24.0 \mathrm{~m}$ tall \\
Stem Densities (no./plot) & \\
\hline Sapling & Number of woody stems (shrub or tree) less than $7.6 \mathrm{~cm}$ dbh \\
Small tree & within a $5 \mathrm{~m}$ radius of nest \\
Medium tree & Number of trees $7.6-22.9 \mathrm{~cm}$ trees dbh within an $11.3 \mathrm{~m}$ radius of nest \\
Large tree & Number of trees $23.0-38.0 \mathrm{~cm}$ dbh within an $11.3 \mathrm{~m}$ radius of nest \\
Snag & Number of trees $>38.0 \mathrm{~cm}$ dbh within an $11.3 \mathrm{~m}$ radius of nest \\
\hline
\end{tabular}


Table 3. Chi-square goodness-of-fit analysis and Bonferroni 95\% confidence intervals (C.I.) for the occurrence of four thrush species in relation to the availability of land cover types on the MeadWestvaco Wildlife and Ecosystem Research Forest and the Panther Run Tract, Randolph County, West Virginia during 2001-2003.

\begin{tabular}{|c|c|c|c|c|c|c|c|}
\hline \multirow[b]{2}{*}{ Species/land cover } & \multicolumn{4}{|c|}{ Point counts used } & \multicolumn{2}{|c|}{ Point counts available } & \multirow[b]{2}{*}{ Selection } \\
\hline & $\mathrm{n}$ & $\%$ & & o C.I. & $\mathrm{n}$ & $\%$ & \\
\hline \multicolumn{8}{|l|}{ American robin } \\
\hline Even-aged harvest & 8 & 12.1 & 1.5 & -22.7 & 23 & 5.3 & None \\
\hline Mature deciduous & 16 & 24.2 & 10.3 & $-\quad 38.2$ & 96 & 22.2 & None \\
\hline Mature mixed & 13 & 19.7 & 6.8 & $-\quad 32.6$ & 111 & 25.7 & None \\
\hline Deciduous partial & 1 & 1.5 & -2.5 & $-\quad 5.5$ & 49 & 11.3 & Against \\
\hline Mixed partial & 14 & 21.2 & 7.9 & -34.5 & 79 & 18.3 & None \\
\hline Edge & 14 & 21.2 & 7.9 & -34.5 & 74 & 17.1 & None \\
\hline \multicolumn{8}{|l|}{ Hermit thrush } \\
\hline Even-aged harvest & 0 & 0.0 & 0.0 & $\begin{array}{l}-\quad 0.0 \\
-10\end{array}$ & 21 & 6.2 & Against \\
\hline Mature deciduous & 3 & 7.7 & -3.6 & $-\quad 18.9$ & 82 & 24.0 & Against \\
\hline Mature mixed & 23 & 59.0 & 38.2 & - 79.8 & 100 & 29.3 & For \\
\hline Deciduous partial & 0 & 0.0 & 0.0 & $\begin{array}{l}-\quad 0.0 \\
-10\end{array}$ & 10 & 2.9 & Against \\
\hline Mixed partial & 11 & 28.2 & 9.2 & -47.2 & 69 & 20.2 & None \\
\hline Edge & 2 & 5.1 & -4.2 & -14.4 & 59 & 17.3 & Against \\
\hline \multicolumn{8}{|l|}{ Veery } \\
\hline Even-aged harvest & 16 & 8.5 & 3.1 & - 13.9 & 23 & 5.3 & None \\
\hline Mature deciduous & 45 & 23.9 & 15.7 & $-\quad 32.1$ & 96 & 22.2 & None \\
\hline Mature mixed & 44 & 23.4 & 15.3 & -31.6 & 111 & 25.7 & None \\
\hline Deciduous partial & 10 & 5.3 & 1.0 & - 9.6 & 49 & 11.3 & Against \\
\hline Mixed partial & 44 & 23.4 & 15.3 & -31.6 & 79 & 18.3 & None \\
\hline Edge & 29 & 15.4 & 8.5 & -22.4 & 74 & 17.1 & None \\
\hline \multicolumn{8}{|l|}{ Wood thrush } \\
\hline Even-aged harvest & 4 & 6.3 & -1.8 & -14.5 & 20 & 5.4 & None \\
\hline Mature deciduous & 11 & 17.4 & 4.8 & -30.1 & 82 & 22.2 & None \\
\hline Mature mixed & 10 & 15.9 & 3.7 & -28.0 & 90 & 24.3 & None \\
\hline Deciduous partial & 19 & 30.2 & 14.9 & -45.4 & 49 & 13.2 & For \\
\hline Mixed partial & 10 & 15.9 & 3.7 & -28.0 & 64 & 17.3 & None \\
\hline Edge & 9 & 14.3 & 2.7 & $-\quad 25.9$ & 65 & 17.6 & None \\
\hline
\end{tabular}


Table 4. Nest survival rate and standard error (SE) of 128 nests for which survival was calculated, and $\chi^{2}$ contingency table analysis within each thrush species among land cover types during 2001-2003 on the MeadWestvaco Wildlife and Ecosystem Research Forest and the Panther Run Tract, Randolph County, West Virginia. Means with different letters differ at $P<$ 0.05 .

\begin{tabular}{|c|c|c|c|c|c|c|c|c|}
\hline \multirow[b]{2}{*}{ Species/land cover } & \multirow{2}{*}{$\begin{array}{l}\text { No. nests } \\
\text { monitored }\end{array}$} & \multirow{2}{*}{$\begin{array}{l}\text { No. nests } \\
\text { depredated }\end{array}$} & \multirow{2}{*}{$\begin{array}{c}\text { Days } \\
\text { observed }\end{array}$} & \multicolumn{3}{|c|}{ Survival } & \multirow[b]{2}{*}{$\chi 2 \mathrm{a}$} & \multirow[b]{2}{*}{$P$} \\
\hline & & & & Percent & & $\mathrm{SE}$ & & \\
\hline \multicolumn{9}{|l|}{ American robin } \\
\hline Even-aged Harvest & 3 & $\mathbf{0}$ & 62.0 & 100 & $\mathbf{A}$ & 0.0 & $4.5 \mathrm{E}+19$ & $<0.01$ \\
\hline Mature forest & 8 & 3 & 139.0 & 53.6 & B & 1.5 & & \\
\hline Mature deciduous & 2 & 1 & 22.5 & 23.6 & & 0.6 & & \\
\hline Mature mixed & 6 & 2 & 116.5 & 60.1 & & 0.1 & & \\
\hline Partial harvest & 5 & 3 & 13.0 & $\mathbf{0 . 0}$ & $\mathbf{C}$ & 0.0 & & \\
\hline Deciduous partial & 1 & 1 & 1.5 & 0.0 & & 0.0 & & \\
\hline Mixed partial & 4 & 2 & 11.5 & 0.0 & & 0.0 & & \\
\hline \multicolumn{9}{|l|}{ Hermit thrush } \\
\hline Even-aged Harvest & $\mathbf{0}$ & & & & & & & \\
\hline Mature forest & 22 & 11 & 240.0 & 27.9 & $\mathbf{A}$ & 0.0 & 7.0 & 0.01 \\
\hline Mature deciduous & 5 & 3 & 55.5 & 25.6 & & 2.6 & & \\
\hline Mature mixed & 17 & 8 & 184.5 & 29.1 & & 0.8 & & \\
\hline Partial harvest & 4 & 3 & 59.5 & 20.9 & B & 2.7 & & \\
\hline Deciduous partial & 1 & 1 & 17.0 & 15.7 & & 8.8 & & \\
\hline Mixed partial & 3 & 2 & 42.5 & 25.2 & & 3.9 & & \\
\hline \multicolumn{9}{|l|}{ Veery } \\
\hline Even-aged Harvest & 4 & 1 & 55.0 & 68.9 & A & 3.2 & 223.6 & $<0.01$ \\
\hline Mature forest & 26 & 7 & 210.5 & 34.4 & B & 0.7 & & \\
\hline Mature deciduous & 18 & 6 & 131.5 & 30.1 & & 1.0 & & \\
\hline Mature mixed & 8 & 1 & 79.0 & 43.5 & & 2.0 & & \\
\hline Partial harvest & 14 & 9 & 144.5 & 20.4 & C & 1.0 & & \\
\hline Deciduous partial & 7 & 5 & 59.0 & 13.6 & & 1.7 & & \\
\hline Mixed partial & 7 & 4 & 85.5 & 34.5 & & 2.0 & & \\
\hline \multicolumn{9}{|l|}{ Wood thrush } \\
\hline Even-aged Harvest & 7 & 4 & 79.0 & 29.5 & A & 21.9 & 130.5 & $<0.01$ \\
\hline Mature forest & 20 & 11 & 151 & 14.1 & C & 10.9 & & \\
\hline Mature deciduous & 16 & 10 & 88.5 & 7.4 & & 7.4 & & \\
\hline Mature mixed & 4 & 1 & 62.5 & 58.3 & & 58.3 & & \\
\hline Partial harvest & 20 & 12 & 190.0 & 23.9 & B & 23.9 & & \\
\hline Deciduous partial & 18 & 12 & 168.0 & 19.9 & & 19.9 & & \\
\hline Mixed partial & 2 & 0 & 22.0 & 100.0 & & 0.0 & & \\
\hline
\end{tabular}

${ }^{a}$ Chi square analysis was performed on groupings of deciduous and mixed forest, indicated in bold. Sub-categories were precluded from analysis due to small sample sizes and are shown for comparison purposes only. 
Table 5. Means and standard errors (SE) of microhabitat variables sampled at randomly located plots within three land cover categories at the MeadWestvaco Wildlife and Ecosystem Research Forest and the Panther Run Tract, Randolph County, West Virginia during 2001-2003. Within a row, means with different letters differed among land cover categories at $P<0.05$.

\begin{tabular}{|c|c|c|c|c|c|c|c|c|}
\hline \multirow[b]{2}{*}{ Variable } & \multicolumn{2}{|c|}{$\begin{array}{l}\text { Clearcut } \\
(\mathrm{n}=12)\end{array}$} & \multicolumn{2}{|c|}{$\begin{array}{l}\text { Mature Forest } \\
\quad(\mathrm{n}=75)\end{array}$} & \multicolumn{2}{|c|}{$\begin{array}{l}\text { Partial } \\
(\mathrm{n}=42)\end{array}$} & \multirow[b]{2}{*}{ F } & \multirow[b]{2}{*}{$P$} \\
\hline & Mean & SE & Mean & SE & Mean & SE & & \\
\hline Canopy height (m) & $17.8 \mathrm{~B}$ & 2.6 & $21.3 \mathrm{~A}$ & 0.4 & $19.4 \mathrm{AB}$ & 0.9 & 3.98 & 0.0212 \\
\hline Distance to edge (m) & 21.0 & 7.2 & 20.6 & 3.2 & 17.5 & 2.6 & 0.25 & 0.7816 \\
\hline Slope (\%) & 25.8 & 3.5 & 24.1 & 1.5 & 22.2 & 1.9 & 0.48 & 0.6216 \\
\hline Aspect & 1.0 & 0.2 & 0.9 & 0.1 & 0.8 & 0.1 & 0.61 & 0.5453 \\
\hline \multicolumn{9}{|l|}{ Groundcover (\%) } \\
\hline Herbaceous & 27.5 & 7.3 & 21.5 & 2.0 & 23.5 & 3.0 & 0.68 & 0.5109 \\
\hline Litter & 52.5 & 6.2 & 57.7 & 2.5 & 50.6 & 2.9 & 1.86 & 0.1599 \\
\hline Woody debris & 10.8 & 3.3 & 10.6 & 0.9 & 10.7 & 1.3 & 0.06 & 0.9432 \\
\hline Bare & $5.0 \mathrm{~B}$ & 1.8 & $6.8 \mathrm{AB}$ & 1.5 & $11.3 \mathrm{~A}$ & 2.0 & 3.87 & 0.0233 \\
\hline Moss & 3.8 & 1.1 & 3.2 & 0.6 & 3.3 & 0.8 & 0.33 & 0.7215 \\
\hline Water & 0.4 & 0.4 & 0.3 & 0.1 & 0.2 & 0.2 & 0.23 & 0.7909 \\
\hline \multicolumn{9}{|l|}{ Canopy cover (\%) } \\
\hline $3 \mathrm{~m}$ & $72.5 \mathrm{~A}$ & 7.8 & $54.2 \mathrm{~B}$ & 2.9 & $54.0 \mathrm{~B}$ & 4.1 & 3.52 & 0.0324 \\
\hline $3-6 \mathrm{~m}$ & 53.3 & 8.5 & 59.5 & 2.9 & 56.0 & 4.0 & 0.66 & 0.5166 \\
\hline $6-12 \mathrm{~m}$ & $41.3 \mathrm{~B}$ & 10.0 & $68.3 \mathrm{~A}$ & 2.8 & $58.7 \mathrm{~A}$ & 4.5 & 5.68 & 0.0043 \\
\hline $12-18 \mathrm{~m}$ & $47.5 \mathrm{~B}$ & 11.4 & $73.8 \mathrm{~A}$ & 2.5 & $62.7 \mathrm{~A}$ & 4.4 & 7.02 & 0.0013 \\
\hline $18-24 \mathrm{~m}$ & 40.8 & 10.0 & 53.8 & 3.6 & 44.5 & 4.8 & 1.96 & 0.1447 \\
\hline$>24 \mathrm{~m}$ & 0.0 & 0.0 & 6.5 & 1.8 & 3.2 & 1.8 & 2.25 & 0.1100 \\
\hline \multicolumn{9}{|l|}{ Stem density } \\
\hline Sapling & $157.4 \mathrm{~A}$ & 41.7 & $62.5 \mathrm{~B}$ & 7.5 & $123.9 \mathrm{~A}$ & 16.3 & 10.96 & $<0.0001$ \\
\hline Small tree & $5.7 \mathrm{~B}$ & 1.7 & $11.8 \mathrm{~A}$ & 0.8 & $8.5 \mathrm{~A}$ & 0.8 & 8.36 & 0.0004 \\
\hline Medium tree & 4.0 & 1.0 & 5.5 & 0.4 & 4.7 & 0.4 & 2.35 & 0.0998 \\
\hline Large tree & 2.2 & 0.6 & 2.2 & 0.2 & 2.1 & 0.3 & 0.43 & 0.6518 \\
\hline Snag & 1.0 & 0.5 & 2.6 & 0.3 & 1.8 & 0.3 & 3.18 & 0.0451 \\
\hline
\end{tabular}


Table 6. Microhabitat variables that differed between the nest sites of four thrush species and paired, randomly located plots at the MeadWestvaco Wildlife and Ecosystem Research Forest and the Panther Run Tract, Randolph County, West Virginia during 2001-2003.

\begin{tabular}{|c|c|c|c|c|c|c|c|c|}
\hline \multirow[b]{2}{*}{ Species/variable } & \multirow[b]{2}{*}{ Land cover } & \multirow{2}{*}{$\begin{array}{l}\text { No. } \\
\text { nests }\end{array}$} & \multicolumn{2}{|c|}{ Nest sites } & \multicolumn{2}{|c|}{ Random plots } & \multirow[b]{2}{*}{$t$} & \multirow[b]{2}{*}{$P$} \\
\hline & & & Mean & SE & Mean & SE & & \\
\hline \multicolumn{9}{|l|}{ American robin } \\
\hline \multicolumn{9}{|l|}{ Groundcover (\%) } \\
\hline Herbaceous & Mature forest & 5 & 20.0 & 3.5 & 9.0 & 1.0 & 3.59 & 0.02 \\
\hline Litter & Mature forest & 5 & 39.0 & 12.1 & 66.0 & 4.8 & -3.21 & 0.03 \\
\hline Moss & Mature forest & 5 & 25.0 & 9.7 & 7.0 & 3.0 & 3.33 & 0.03 \\
\hline \multicolumn{9}{|l|}{ Canopy cover $(\%)$} \\
\hline $3 \mathrm{~m}$ & Clearcut & 2 & 90.0 & 10.0 & 30.0 & 20.0 & $>1000$ & $<0.01$ \\
\hline $12-18 \mathrm{~m}$ & Mature forest & 5 & 25.0 & 16.4 & 79.0 & 7.6 & -2.84 & 0.05 \\
\hline \multicolumn{9}{|l|}{ Stem density } \\
\hline Small tree & Mature forest & 5 & 4.2 & 1.3 & 12.4 & 2.1 & -3.64 & 0.02 \\
\hline Medium tree & Mature forest & 5 & 0.6 & 0.4 & 7.4 & 1.2 & -13.83 & $<0.01$ \\
\hline Large tree & Mature forest & 5 & 0.2 & 0.2 & 2.6 & 0.7 & -3.66 & 0.02 \\
\hline \multicolumn{9}{|l|}{ Hermit thrush } \\
\hline Canopy height (m) & Mature forest & 23 & 19.2 & 19.2 & 20.5 & 0.6 & -2.80 & 0.01 \\
\hline \multicolumn{9}{|l|}{ Groundcover (\%) } \\
\hline Litter & Mature forest & 23 & 36.5 & 5.0 & 63.5 & 4.7 & -4.31 & $<0.01$ \\
\hline Woody debris & Mature forest & 23 & 3.3 & 1.0 & 7.0 & 1.5 & -2.10 & 0.05 \\
\hline Moss & Mature forest & 23 & 20.0 & 4.6 & 3.9 & 0.9 & 3.94 & $<0.01$ \\
\hline \multicolumn{9}{|l|}{ Canopy cover (\%) } \\
\hline $3-6 m$ & Mature forest & 23 & 43.0 & 5.1 & 68.9 & 5.0 & -3.30 & $<0.01$ \\
\hline $6-12 \mathrm{~m}$ & Mature forest & 23 & 46.0 & 6.0 & 74.6 & 4.2 & -3.79 & $<0.01$ \\
\hline $12-18 \mathrm{~m}$ & Mature forest & 23 & 36.5 & 6.3 & 71.7 & 4.6 & -3.97 & $<0.01$ \\
\hline $18-24 \mathrm{~m}$ & Mature forest & 23 & 18.7 & 6.1 & 44.6 & 6.5 & -2.98 & 0.01 \\
\hline \multicolumn{9}{|l|}{ Stem density } \\
\hline Sapling & Mature forest & 23 & 75.8 & 17.8 & 29.0 & 7.2 & 3.32 & 0.01 \\
\hline \multicolumn{9}{|l|}{ Veery } \\
\hline \multicolumn{9}{|l|}{ Groundcover (\%) } \\
\hline Woody debris & Partial & 12 & 20.8 & 4.7 & 10.8 & 2.9 & 2.25 & 0.05 \\
\hline \multicolumn{9}{|l|}{ Canopy cover $(\%)$} \\
\hline $3 \mathrm{~m}$ & Partial & 12 & 71.7 & 6.9 & 49.6 & 6.4 & 2.45 & 0.03 \\
\hline $18-24 \mathrm{~m}$ & Mature forest & 23 & 35.2 & 6.9 & 57.2 & 7.0 & -2.16 & 0.04 \\
\hline \multicolumn{9}{|l|}{ Stem density } \\
\hline Sapling & Mature forest & 23 & 158.2 & 20.6 & 104.1 & 16.5 & 2.65 & 0.01 \\
\hline Medium tree & Partial & 12 & 3.2 & 0.8 & 4.6 & 0.9 & -3.11 & 0.01 \\
\hline
\end{tabular}


Table 6, Cont'd.

\begin{tabular}{|c|c|c|c|c|c|c|c|c|}
\hline \multirow[b]{2}{*}{ Species/variable } & \multirow[b]{2}{*}{ Land cover } & \multirow{2}{*}{$\begin{array}{l}\text { No. } \\
\text { nests }\end{array}$} & \multicolumn{2}{|c|}{ Nest sites } & \multicolumn{2}{|c|}{ Random plots } & \multirow[b]{2}{*}{$t$} & \multirow[b]{2}{*}{$P$} \\
\hline & & & Mean & SE & Mean & SE & & \\
\hline \multicolumn{9}{|l|}{ Wood thrush } \\
\hline \multicolumn{9}{|c|}{ Groundcover (\%) } \\
\hline Moss & Clearcut & 8 & 1.3 & 0.8 & 5.0 & 1.3 & -3.01 & 0.02 \\
\hline \multicolumn{9}{|c|}{ Canopy cover (\%) } \\
\hline $12-18 \mathrm{~m}$ & Mature forest & 19 & 72.1 & 5.0 & 81.6 & 3.5 & -2.95 & 0.01 \\
\hline \multicolumn{9}{|l|}{ Stem density } \\
\hline Sapling & Mature forest & 19 & 108.3 & 19.5 & 63.4 & 14.3 & 2.21 & 0.04 \\
\hline
\end{tabular}


Table 7. Variables measured at nest sites of four thrush species that differed among nests placed within three land cover categories during 2001-2003 at the MeadWestvaco Wildlife and Ecosystem Research Forest and the Panther Run Tract, Randolph County, West Virginia. Within a row, means with different letters differed at $P<0.05$.

\begin{tabular}{|c|c|c|c|c|c|c|c|c|}
\hline \multirow[b]{2}{*}{ Species/Variable } & \multicolumn{2}{|c|}{ Clearcut } & \multicolumn{2}{|c|}{ Mature Forest } & \multicolumn{2}{|c|}{$\underline{\text { Partial Harvest }}$} & \multirow[b]{2}{*}{$\mathrm{F}$} & \multirow[b]{2}{*}{$P$} \\
\hline & Mean & SE & Mean & $\mathrm{SE}$ & Mean & SE & & \\
\hline \multicolumn{9}{|l|}{ American robin $(\mathrm{n}=17)$} \\
\hline \multicolumn{9}{|l|}{ Canopy cover $(\%)$} \\
\hline $3.0 \mathrm{~m}$ & $83.3 \mathrm{~A}$ & 8.8 & $54.4 \mathrm{~B}$ & 4.6 & $44.2 \mathrm{~B}$ & 8.9 & 6.14 & 0.01 \\
\hline $6.1-12.0 \mathrm{~m}$ & $8.3 \mathrm{~B}$ & 8.3 & $32.5 \mathrm{~A}$ & 8 & $58.3 \mathrm{~A}$ & 9.3 & 7.20 & 0.01 \\
\hline$>24.0 \mathrm{~m}$ & $0.0 \mathrm{~B}$ & 0 & $0.0 \mathrm{AB}$ & 0 & $14.2 \mathrm{~A}$ & 7.5 & 4.02 & 0.04 \\
\hline \multicolumn{9}{|l|}{$\underline{\text { Hermit thrush }(\mathrm{n}=28)}$} \\
\hline Distance to edge $(\mathrm{m})$ & & & $4.4 \mathrm{~B}$ & 1.3 & $18.3 \mathrm{~A}$ & 7.8 & 10.10 & $<0.01$ \\
\hline \multicolumn{9}{|l|}{ Stem density } \\
\hline Sapling & & & $75.6 \mathrm{~B}$ & & $270.3 \mathrm{~A}$ & 93.7 & 10.86 & $<0.01$ \\
\hline Large tree & & & $1.4 \mathrm{~B}$ & 0.3 & $3.8 \mathrm{~A}$ & 1.0 & 5.40 & 0.03 \\
\hline \multicolumn{9}{|l|}{$\underline{\text { Veery }(n=46)}$} \\
\hline \multicolumn{9}{|l|}{ Groundcover (\%) } \\
\hline Herbaceous & $62.5 \mathrm{~A}$ & 9.2 & $22.9 \mathrm{~B}$ & 4.2 & $25.0 \mathrm{~B}$ & 3.4 & 5.98 & 0.01 \\
\hline Litter & $18.8 \mathrm{~B}$ & 2.4 & $56.5 \mathrm{~A}$ & 4.8 & $52.5 \mathrm{~A}$ & 4.7 & 4.71 & 0.01 \\
\hline \multicolumn{9}{|l|}{ Canopy cover $(\%)$} \\
\hline $3 \mathrm{~m}$ & $48.8 \mathrm{~B}$ & 14 & $52.7 \mathrm{~B}$ & 4.4 & $70.0 \mathrm{~A}$ & 5.9 & 3.75 & 0.03 \\
\hline $3.1-6.0 \mathrm{~m}$ & $15.0 \mathrm{~B}$ & 6.1 & $55.0 \mathrm{~A}$ & 5.1 & $54.1 \mathrm{~A}$ & 6.9 & 4.30 & 0.02 \\
\hline $6.1-12.0 \mathrm{~m}$ & $10.0 \mathrm{~B}$ & 5.4 & $64.8 \mathrm{~A}$ & 5.3 & $44.7 \mathrm{~A}$ & 8.3 & 7.06 & $<0.01$ \\
\hline $12.1-18.0 \mathrm{~m}$ & $18.8 \mathrm{~B}$ & 7.2 & $62.1 \mathrm{~A}$ & 5.2 & $51.6 \mathrm{~A}$ & 8.1 & 3.66 & 0.03 \\
\hline \multicolumn{9}{|l|}{ Stem density } \\
\hline Sapling & $284.8 \mathrm{~A}$ & 58.9 & $153.8 \mathrm{C}$ & 19 & 247.4 B & 38.3 & 3.06 & 0.06 \\
\hline Small tree & $2.5 \mathrm{~B}$ & 1.6 & $10.7 \mathrm{~A}$ & 1.4 & $10.5 \mathrm{~A}$ & 1.8 & 3.71 & 0.03 \\
\hline Medium tree & $1.3 \mathrm{~B}$ & 0.8 & $4.2 \mathrm{~A}$ & 0.5 & $4.3 \mathrm{~A}$ & 0.9 & 3.58 & 0.04 \\
\hline \multicolumn{9}{|l|}{ Wood thrush $(\mathrm{n}=50)$} \\
\hline Canopy height (m) & $18.0 \mathrm{~B}$ & 2.4 & $22.6 \mathrm{~A}$ & 0.6 & $21.7 \mathrm{~A}$ & 0.6 & 4.77 & 0.01 \\
\hline \multicolumn{9}{|l|}{ Groundcover (\%) } \\
\hline Herbaceous & $32.8 \mathrm{~A}$ & 5.7 & $15.5 \mathrm{~B}$ & 3.2 & $19.3 \mathrm{~B}$ & 3.2 & 3.77 & 0.03 \\
\hline Moss & $1.1 \mathrm{~B}$ & 0.7 & $1.2 \mathrm{~B}$ & 0.5 & $3.5 \mathrm{~A}$ & 0.8 & 3.43 & 0.04 \\
\hline \multicolumn{9}{|l|}{ Canopy cover $(\%)$} \\
\hline $3.0 \mathrm{~m}$ & $86.7 \mathrm{~A}$ & 2.5 & $67.6 \mathrm{~B}$ & 4.5 & $72.8 \mathrm{~B}$ & 3.4 & 4.25 & 0.02 \\
\hline $12.1-18.0 \mathrm{~m}$ & $40.6 \mathrm{~B}$ & 13.2 & $69.5 \mathrm{~A}$ & 5 & $69.3 \mathrm{~A}$ & 6.5 & 4.83 & 0.01 \\
\hline $18.1-24.0 \mathrm{~m}$ & $30.6 \mathrm{~B}$ & 13.9 & $66.9 \mathrm{~A}$ & 6.6 & $57.5 \mathrm{~A}$ & 7.6 & 3.44 & 0.04 \\
\hline
\end{tabular}


Table 7., Cont'd.

\begin{tabular}{|c|c|c|c|c|c|c|c|c|}
\hline \multirow[b]{2}{*}{ Species/Variable } & \multicolumn{2}{|c|}{ Clearcut } & \multicolumn{2}{|c|}{ Mature Forest } & \multicolumn{2}{|c|}{ Partial Harvest } & \multirow[b]{2}{*}{$\mathrm{F}$} & \multirow[b]{2}{*}{$P$} \\
\hline & Mean & SE & Mean & SE & Mean & SE & & \\
\hline \multicolumn{9}{|l|}{ Wood thrush $(\mathrm{n}=50)$} \\
\hline \multicolumn{9}{|l|}{ Stem density } \\
\hline Small tree & $5.8 \mathrm{~B}$ & 1.3 & $10.9 \mathrm{~A}$ & 1.2 & 7.7 AB & 0.8 & 5.13 & 0.01 \\
\hline Medium tree & $2.2 \mathrm{~B}$ & 1.1 & $5.2 \mathrm{~A}$ & 0.9 & $3.7 \mathrm{~A}$ & 0.4 & 6.33 & $<0.01$ \\
\hline Snag & $0.2 \mathrm{~B}$ & 0.1 & $2.4 \mathrm{~A}$ & 0.6 & $1.0 \mathrm{AB}$ & 0.3 & 4.06 & 0.02 \\
\hline
\end{tabular}




\section{VITA}

\section{Rachel Dellinger}

Rachel Dellinger was born Rachel Lynette Ridall on June 10, 1971 in Paris, Illinois. She graduated from Collinwood High School in Collinwood, Tennessee in 1989 and entered the University of New Mexico at Albuquerque in the same year. She graduated from the University of Tennessee at Knoxville in 1994 with a Bachelor of Science degree in biology with a concentration in ecology. In 1997 she enrolled in a master's program at East Tennessee State University in Johnson City. Under the guidance of Dr. Fred Alsop, she studied the mobbing behavior of passerines in response to the songs of the Eastern Screech-owl and the Northern Saw-whet Owl, and received her Master of Science degree in biology in 1998.

She held several jobs in the wildlife field, including traveling with and caring for captive birds of prey; searching for nests of the Golden-winged Warbler; finding nests of and mistnetting American Swallow-tailed Kites; trapping and radio-tracking Short-tailed Hawks; banding owls; and conducting nocturnal surveys for Northern Saw-whet Owls. She also worked as an algebra and biology tutor and as a biology lab instructor. Other wildlife-related experiences included falconry, birding, and work as a volunteer environmental educator.

In May 2001 she entered the doctoral program at West Virginia University where she worked on the songbird portion of the Appalachian Landscape Ecology Project, a long-term landscape-level project funded by MeadWestvaco Corporation concerning the effects of forest management on wildlife. Additionally, she taught three courses while at WVU: Vertebrate Natural History, Natural Resources of West Virginia, and Conservation Biology. On August 11, 2001 she married Timothy Allen Dellinger, and on May 7, 2004 gave birth to her son, William Thomas Dellinger. She graduated with her Ph.D. in December 2005. 